\title{
Dependent Sovereigns: Indian Tribes, States, and the Federal Courts
}

\author{
Judith Resnik† \\ Table of Contents
}

Introduction

I. Creating the Boundaries of Jurisprudential Thought About the Federal Courts ..................... 680

A. A Course of Study .................. 681

B. Premises of the Law of Federal Courts ...... 687

II. The Indian Tribes' Relationship to the United States 690

III. Reasons to Give Voice .................... 701

A. The Interdependencies of Norms .......... 702

1. Sovereignty and Membership .......... 702

2. New and Old Customs............... 705

3. Codification of Membership Rules ........ 712

4. The Need for Membership .............. 719

5. The Benefits of Membership ........... 720

6. Membership and Gender.............. 722

7. Joint Venturing .................. 725

B. Separate but Assimilated ................ 727

1. Sovereignty and Jurisdiction ........... 729

2. Tribal Courts, Federal Courts, and State Courts ........................... 734

3. Federal Oversight via Relitigation ........ 738

IV. The Lessons Learned ..................... 742

A. Familiar but Altered Themes ............. 742

B. The Question of Survival of the "Other" Courts 745

C. The Assimilationist Pressures . . . . . . . . . . . 747

D. The Utility of the "Other" .............. 749

Conclusion $\ldots \ldots \ldots \ldots \ldots \ldots \ldots \ldots \ldots \ldots \ldots, 758$

$\uparrow$ Professor of Law, University of Southern California Law Center. This research has been supported by funds from the University of Southern California Faculty Research Program, the University of Chicago Law School, and Yale Law School. I had a lot of help. My thanks to Bruce Ackerman, Akhil Amar, Barbara Atwood, Milner Ball, Carol Bacon, Scott Bice, Boris Bittker, Richard Collins, Dennis Curtis, Perry Dane, Suzanne Dohrer, Nina Finston, Ron Garet, Barbara Herman, Jennifer Hermann, Vicki Jackson, Hannah Lauck, Lester Marston, Martha Minow, Donna Murphy, Michael Proctor, Rachel Seidman, Rebecca Shroff, Avi Soifer, Cass Sunstein, Mary Ann Soden, Alan Taradash, Mark Tushnet, Robert Williams, and the participants at faculty workshops at Northwestern University School of Law, the University of Southern California Law Center, and Yale Law School. 


\section{INTRODUCTION}

In 1941, Julia Martinez, a member of the Santa Clara Pueblo, and Myles Martinez, a Navajo, were married. The couple resided on the Santa Clara Pueblo; they had several children. In 1939, the Santa Clara Pueblo promulgated an ordinance detailing its membership rules. The ordinance provided that children of female members who married outside the Pueblo would not be Santa Clarans, while children of male members who married outside the Pueblo would be members. In the early 1970s, Julia Martinez and her daughter Audrey filed a lawsuit under Title I of the Indian Civil Rights Act (ICRA) of 1968. ${ }^{1}$ Having been unsuccessful in their efforts to persuade the Pueblo to change its membership rules, Julia and Audrey Martinez asked the federal court for declaratory and injunctive relief - to invalidate the Santa Clara Pueblo's ordinance and to require that the Pueblo count the Martinez children as members.

In 1978, the United States Supreme Court decided the case of Santa Clara Pueblo v Martinez. ${ }^{2}$ Justice Thurgood Marshall, writing for the majority, interpreted Title I of the ICRA to impose "certain restrictions upon tribal governments similar, but not identical, to those contained in the Bill of Rights and the Fourteenth Amendment."3 However, the only express jurisdictional and remedial provision of the statute was habeas corpus. Martinez $v$ Santa Clara Pueblo thus raised the question of whether the federal court should imply a right of action and federal court jurisdiction to hear the alleged violation of the Indian Civil Rights Act. According to

125 USC $\S \S 1301-1303$ (1982). This legislation borrows much of its language from the federal Bill of Rights. See notes 3 and 265 and accompanying text. The lawsuit was filed against both the Pueblo tribe and its Governor. The Supreme Court held that the "common-law immunity from suit traditionally enjoyed by sovereign powers" such as Indian tribes had not been expressly abrogated by the Indian Civil Rights Act, and thus the suit against the tribe (but not its governor) was barred. Santa Clara Pueblo v Martinez, 436 US $49,58-59$ (1978). The holding parallels doctrine about states' immunity under the Eleventh Amendment; while state immunity can only be abrogated by clear statements of Congress or waived by the states, state officials can be sued. See, for example, Ex parte Young, 209 US 123 (1908).

2436 US 49 (1978).

${ }^{3}$ Id at 57 (footnote quoting the relevant provisions of ICRA omitted). The Bill of Rights and Fourteenth Amendment do not constrain tribal government activities. Talton $v$ Mayes, 163 US 376, 384 (1896) held the Fifth Amendment inapplicable to a claim by a Cherokee against the Cherokee Nation, whose powers of local government "existed prior to the Constitution." For the series of cases which, building on Talton, held other aspects of the Bill of Rights inapplicable to tribes, see Santa Clara Pueblo, 436 US at 56 \& n 7. For analysis of Justice Marshall's approach to federal Indian law, see Robert Laurence, Thurgood Marshall's Indian Law Opinions, 27 Howard L J 3 (1984). 
the Court, implication of a right of action and federal court review for claims such as those raised by Julia and Audrey Martinez would undermine the Congressional purpose of preserving "tribal sovereignty" and "self-government." Therefore, no implied cause of action existed, and the federal courts could not hear the discrimination charge. ${ }^{5}$

Santa Clara Pueblo is a major case in federal Indian law. Santa Clara Pueblo also offers a fascinating illustration of how the United States government conceives of its citizens as holding simultaneous membership in two political entities. According to the Indian Citizenship Act of 1924, all Indians are United States citizens, but that citizenship cannot "impair or otherwise affect" their rights to tribal property. ${ }^{6}$ The 1968 Indian Civil Rights Act pro-

- Santa Clara Pueblo, 436 US at 62-64. Similar cases in Canada involve Indian women who married non-Indians and were subsequently excluded from their status as Indians. See Kathleen Jamieson, Indian Women and the Law of Canada: Citizens Minus (Canadian Ministry of Supply and Services, 1978). In a five to four decision, the Supreme Court of Canada ruled against the two women claimants who challenged the exclusion. Id at 84-85. See also Attorney-General of Canada v Laveel; Isaac v Bedard, 38 DLR (3rd) 481 (1973). Subsequently, in another case also involving the exclusion of an Indian woman (Sandra Lovelace) from a reservation, the Human Rights Committee of the United Nations found Canada to be in violation of the International Covenant on Civil and Political Rights. See Report of the Human Rights Committee, General Assembly, 36th Sess, Supplement No 40 (A/36/40) (UN, 1981).

- Under Navajo law, the Martinez children may have been eligible to be counted as Navajos. The Navajo Tribal Code sets forth three categories of individuals who may qualify for membership: those "of Navajo blood" who were on Bureau of Indian Affairs' rolls prior to the time when the Navajos began to keep membership rolls; children of a member of the tribe who are at least one quarter Navajo; and those of at least one quarter Navajo blood who apply to the Enrollment Screening Committee, which considers a variety of factors including whether an applicant lives on the reservation and whether the applicant speaks the language. Navajo Tribal Code $\S \S 1-501,551-553 ; 2-2201$. The Martinez children, however, lived on the Santa Clara Pueblo, spoke Tewa, the language of the Pueblo, and were religiously and culturally affiliated with the Santa Clarans.

- Pub L No 175, 43 Stat 253 (1924). The current provision for Indian citizenship, codified at 8 USC $\$ 1401(b)(1982)$, states that all persons "born in the United States to a member of an Indian, Eskimo, Aleutian or other aboriginal tribe" shall be "nationals and citizens" of the United States and their interests in tribal property shall not be affected.

Before 1924, a variety of provisions affected Indian citizenship in the United States. Under the Civil Rights Act of April 10, 1866, ch 31, 14 Stat 27, Congress had provided that "all persons born in the United States and not subject to any foreign power, excluding Indians not taxed, are hereby declared to be citizens of the United States." See also Elk $v$ Wilkins, 112 US 94 (1884) (Indians not citizens for 14th Amendment purposes).

Nonetheless, Indians could obtain United States citizenship under certain conditions. For example, some treaties provided for Indians to be citizens of the United States, as did some statutes. At least in theory, other Indians could obtain citizenship upon receipt of land allotments. See General Allotment Act (Indian Lands) § 6, 24 Stat 388 (1887). The Allotment Act also provided citizenship to those Indians who had "adopted the habits of civilized life." Id. In addition, under the Act of Aug. 9, 1888, § 2, 25 Stat 392, Indian women who married citizens of the United States could also gain citizenship. 
vides that "[n]o Indian tribe in exercising powers of self-government shall ... deny to any person within its jurisdiction the equal protection of its laws." Julia and Audrey Martinez represented a group of Santa Claran women who had married non-Santa Clarans and the children of such marriages. The Martinez women came to federal court to obtain "equal protection." The obvious problem with this claim was the tension arising from being a member of two governments, the Santa Clara Pueblo and the United States.

That tension was addressed by the Court in Santa Clara Pueblo when it declined to imply a private right of action. During the late 1970s, the Court scrutinized a variety of statutory schemes to determine whether private causes of action should be implied. A year after Santa Clara Pueblo was decided, the Court faced the issue again, in a different context. Geraldine Cannon sought recognition of a private right of action under Title IX of the Education Amendments of 1972, which prohibits educational programs that receive federal funds from discriminating on the basis of sex. ${ }^{8} \mathrm{Ms}$. Cannon sued the University of Chicago and other medical schools and alleged that her application had been denied because she was a woman. Unlike in Santa Clara Pueblo, the Court in Cannon $v$ University of Chicago held that, although unstated, Congress had intended to enable private individuals to enforce claims of discrimination - in this instance, against universities. ${ }^{9}$ Both opinions required the Court to make interpretive readings, as defendant institutions (universities and Indian tribes) claimed that Congressional silence and specification of other remedies precluded additional claims, while the women plaintiffs asserted that federal non-subordination rights should be enforced by federal courts against institutions that sought insulation. ${ }^{10}$

In Santa Clara Pueblo, Justice Marshall described the extent of federal control over Indian tribes: All "aspect[s] of tribal sovereignty ... [are] subject to the superior and plenary control of Congress."11 But, Justice Marshall explained, Indian tribes retain a substantial measure of sovereignty; they "remain a 'separate people, with the power of regulating their internal and social relations." "12 Thus, according to the Court, if federal courts were to

\footnotetext{
725 USC $\S 1302(8)$ (1982).

820 USC $\$ 1681$ (1982).

- 441 US 677, 711-16 (1979).

${ }^{10}$ Cass R. Sunstein, Interpreting the Regulatory State (Harvard, forthcoming 1990).

1136 US at 58.

12 Id at 55, quoting United States v Kagama, 118 US 375, 381-82 (1886).
} 
imply a power to "intervene" in tribal decisions, the courts would undermine the authority of a group whose powers have already been limited. "A fortiori, a resolution in a foreign forum of intratribal disputes of a more public character, such as the one in this case, cannot help but unsettle a tribal government's ability to maintain authority."13 Congress intended to protect the tribes from "undue interference."14 Hence, the federal courts should not imply jurisdiction and remedies beyond the one (habeas corpus) specified in the legislation. Julia and Audrey Martinez were sent back to the tribal forum, which had already refused their requests for reconsideration of the tribal ordinance. ${ }^{15}$

Two themes, power and sovereignty, were central to the Santa Clara Pueblo case. Those themes also dominate the scholarship of "federal courts" jurisprudence. ${ }^{16}$ The theme of power, of its allocation and constraint by separation of functions, is typically examined by discussion of the relationships between the federal courts and the Executive, the Congress, and the agencies within the federal government. The theme of sovereignty, often described as "federalism," addresses the relationships among the governmental entities in the United States, and specifically, between the federal courts and the states. A central problem is how two "sovereigns" can and should coexist in the United States. These questions of separation of powers and of federalism arise when

13436 US at 60.

14 Id at 63.

${ }^{25}$ Martinez v Santa Clara Pueblo, 402 F Supp 5, 11 (D NM 1975) "Julia Martinez, individually and with the committee [of other women similarly situated], succeeded in having a special meeting of the entire Pueblo convened to discuss the situation." However, they were not able to persuade the Pueblo to change its rule. Under the Supreme Court ruling, Ms. Martinez, her child, and the class they sought to represent could also have attempted to seek relief from Congress, but, again according to the trial court opinion, Ms. Martinez had already "attended hearings held by the Subcommittee on Constitutional Rights of the United States Senate Committee on the Judiciary, where she sought the help of then Senator Sam Ervin, Jr." Id at 11. See notes 318-34 and accompanying text about current legislative efforts to overturn Santa Clara Pueblo.

${ }^{16}$ For example, in the Preface to the First Edition of Henry M. Hart's and Herbert Wechsler's The Federal Courts and the Federal System xi (Foundation, 1953), the authors described their subject matter as the exploration of "a legal system that derives from both the Nation and the States as separate sources of authority. ..." Also reprinted in Paul M. Bator, Paul J. Mishkin, Daniel J. Meltzer, and David L. Shapiro, Hart and Wechsler's The Federal Courts and the Federal System xxvii (Foundation, 3rd ed 1988). The opening epigram in Felix Frankfurter's and Wilber G. Katz's Cases and Other Authorities on Federal Jurisdiction and Procedure (Natl Casebook Series, 1931) is from Benjamin R. Curtis. The comment, written in 1864, reads: "Let it be remembered, also, - for just now we may be in some danger of forgetting it, - that questions of jurisdiction were questions of power as between the United States and the several States." 
considering the extent of Congressional control over the jurisdiction of the federal courts, ${ }^{17}$ the delineation of responsibilities among the branches of the federal government, ${ }^{18}$ the relationship between the state and federal court systems, ${ }^{19}$ and the distinctive treatment accorded states as litigants in the federal courts. ${ }^{20}$

The bountiful literature of federal courts' jurisprudence does not, however, consider problems of the relationship between Indian tribes, the federal government, and the states. "We" who teach and write about the federal courts, we who list ourselves as the definers of the domain, speak and write relatively rarely about the federal courts and their relationship to Indian tribes. ${ }^{21}$ Santa Clara Pueblo and other "Indian tribe" cases are not often found in books about "the" federal courts or in discussions about the problems of multiple sovereigns coexisting in the United States. While there is a wealth of scholarship about Indian tribes, ${ }^{22}$ that scholarship is not integrated into federal courts' jurisprudence.

This absence of discussion of cases involving Indian tribes is, at one level, odd because these cases are rich in subject matter traditionally found in the federal courts' literature. Questions of power and sovereignty are the questions when Indian tribes seek help from the federal courts or try to resist federal decision making. The issues raised are familiar ones: executive and congres-

${ }^{17}$ See, for example, Lawrence Gene Sager, The Supreme Court: 1980 Term - Foreword: Constitutional Limitations on Congress' Authority to Regulate the Jurisprudence of the Federal Courts, 95 Harv L Rev 17 (1981).

Is See, for example, INS $v$ Chadha, 462 US 919 (1983) (legislative veto); Morrison $v$ Olson, 108 S Ct 2597 (1988) (special prosecutor); Mistretta v United States, 109 S Ct 647 (1989) (sentencing guidelines); Northern Pipeline Co. v Marathon Pipe Line Co., 458 US 50 (1982) (relationship between Article I and Article III courts in the context of bankruptcy).

19 See, for example, Younger v Harris, 401 US 37 (1971) (limiting federal courts' authority to enjoin ongoing state criminal proceedings).

${ }^{20}$ See Martha A. Field, Garcia v San Antonio Metropolitan Transit Authority: The Demise of a Misguided Doctrine, 99 Harv L Rev 84 (1985); Vicki C. Jackson, The Supreme Court, the Eleventh Amendment, and State Sovereign Immunity, 98 Yale L J 1 (1988).

${ }^{21}$ For discussion of the lack of integration of materials about Indians tribes in constitutional law, see Milner S. Ball, Constitution, Court, Indian Tribes, 1987 Am Bar Found Res J 1, 10-11; Charles F. Wilkinson, The Impact of Indian History on the Teaching of American History, Occasional Papers in Curriculum Series of the Newberry Library, D'Arcy McNickle Center for the History of the American Indian, No. 2 (Chicago Conference, 1984) ("Indian History").

${ }^{22}$ These sources are too numerous to list, and many are referred to in other notes in this essay. For overviews, see, for example, Charles F. Wilkinson, American Indians, Time, and the Law (Yale, 1987); Francis Paul Prucha, The Great Father: The United States Government and the American Indians vols I and II (U Nebraska, 1984); Russel Lawrence Barsh and James Youngblood Henderson, The Road: Indian Tribes and Political Liberty (U Cal, 1980); Ball, 1987 Am B Found Res J 1 (cited in note 21). 
sional authority; ${ }^{23}$ the implementation of Supreme Court decisions by the Executive; ${ }^{24}$ the allocation of power between the state and federal courts, ${ }^{25}$ and between states, Indian tribes, and the federal government;" concepts of the attributes and prerogatives of "sovereigns" ${ }^{27}$ such as sovereign immunity ${ }^{28}$ and exhaustion of remedies; ${ }^{29}$ preemption of state or tribal law by federal law; ${ }^{30}$ deference

${ }^{23}$ On the power of Congress, see Delaware Tribal Business Comm. $v$ Weeks, 430 US 73, 84-85 (1977) (Congressional power is "plenary" but not "absolute" and the Court can review congressional distribution of funds to specified Delaware Indians); United States v Kagama, 118 US 375 (1886); Oliphant v Suquamish Indian Tribe, 435 US 191 (1978); United States $v$ Sandoval, 231 US 28 (1913). On the power of the executive branch, see Kerr-McGee Corp. $v$ Navajo Tribe, 471 US 195 (1985) (Secretary of Interior approval not needed for Navajo Tribe ordinance taxing businesses). See also United States $v$ Wilson, 611 F Supp 813, 820 21 (N D Cal 1985) (Department of the Interior lacks authority to abrogate fishing rights); Mashpee Tribe v New Seabury Corp., 592 F2d 575, 580-81 (1st Cir 1979) (court declined to await decision of Department of the Interior decision about tribal status and held trial on issue).

24 See Worcester $v$ Georgia, 31 US 515 (1832). After Chief Justice John Marshall upheld the Cherokee Nation's "sovereign" powers that Georgia had infringed, President Andrew Jackson is said to have remarked: "John Marshall has made his law, now let him enforce it." Wilkinson, Indian History at 111 (cited in note 21).

${ }^{2 s}$ See, for example, Three Affiliated Tribes $v$ Wold Engineering, 476 US 877 (1986) (North Dakota statute on tribal access to state courts preempted by 28 USC $\$ 1360$ ); Colorado River Water Cons. Dist. $v$ United States, 424 US 800 (1976) (even when the United States litigates as trustee for some Indian tribes, federal court must sometimes abstain and defer to on-going state litigation).

${ }^{28}$ See, for example, McClanahan v Arizona State Tax Comm'n, 411 US 164 (1973) (state lacks power to tax Navajos living on a reservation); Washington $v$ Yakima Indian Nation, 439 US 463 (1979) (the power of a state which acts, pursuant to federal statutes, to exercise jurisdiction over cases arising in Indian territory); California v Cabazon Band Mission Indians, $107 \mathrm{~S} \mathrm{Ct} 1083$ (1987) (preemption of state authority to regulate Bingo on a reservation; revised by Indian Gaming Regulatory Act, Pub L No 100-497, 102 Stat 2467 (1988), to be codified at 25 USC $\$ 2701$ (1989), providing for system of regulation). See generally Daniel L. Rotenberg, American States and Indian Tribes: Power Conflicts in the Supreme Court, 92 Dickinson L Rev 81 (1987).

${ }^{27}$ See, for example, Rice v Rehner, 463 US 713, 723 (1983) (state may regulate alcohol sales on reservation); Fisher $v$ District Court of Montana, 424 US 382, 389-90 (1976) (Montana court could not exercise jurisdiction in adoption proceeding involving members of a tribe).

${ }^{28}$ See, for example, Santa Clara Pueblo, 436 US at 58-59. See also Puyallup Tribe $v$ Washington Game Dept., 433 US 165, 171-72 (1977) (sovereign immunity does not protect individual tribe members). Compare U.S. $v$ Yakima Tribal Ct., 806 F2d 853, 858-60 (9th Cir 1986) (tribal court enjoined federal officials from relocating an irrigation canal; tribal court cannot act against the sovereign, the United States absent its consent). The doctrine governing a state's power to enjoin federal officials is comparable; see Tarble's Case, 80 US 397 (1871) (state may not grant habeas corpus relief to an individual in federal custody). See generally Frank Pommersheim and Terry Pechota, Tribal Immunity, Tribal Courts, and the Federal System: Emerging Contours and Frontiers, 31 SD L Rev 553 (1986).

28 Iowa Mut. Ins. Co. v La Plante, 480 US 9 (1987); National Farmers Union Ins. Cos.

v Crow Tribe, 471 US 845, 854-57 (1985); Santa Clara Pueblo, 436 US 49 (1978).

${ }^{30}$ Kagama, 118 US 375; McClanahan v Arizona State Tax Comm, 411 US 164 (1973); Rehner, 463 US 713. 
and comity; ${ }^{31}$ and the federal courts' common law making powers. ${ }^{32}$ Given the similarities between the themes of federal court literature and the subject matter of Indian tribe cases, and given the number of Indian tribe cases decided during the relatively recent past, ${ }^{33}$ the omission (in casebooks and other federal courts scholarly literature) about the relationship between Indian tribes and the federal courts requires explanation.

Recent articles have attempted to understand what Richard Fallon has called the "ideologies of federal courts law"34 - to explicate the underlying assumptions and aspirations of the discipline. This essay continues that enterprise: to consider why federal courts jurisprudence has not spoken much about Indian tribes when telling the story of the federal courts, and to learn what that silence has to teach. I hope to show what Indian tribe cases have to bring to federal courts' jurisprudence, to what is meant by the concept of state sovereignty and allocation of power between the state

31 Santa Clara Pueblo, 436 US at 59-72.

${ }^{32}$ Many federal Indian cases are common law interpretations - for example, those on immunities and some of the jurisdiction cases. See National Farmers Union Ins. Cos. $v$ Crow Tribe, 471 US 845, 850 (1985). See also County of Oneida v Oneida Indian Nation, 470 US 226, 237 (1985) (federal common law used as "necessary expedient," citing Milwaukee v Illinois, 451 US 304, 313-14 (1981)). See generally Martha A. Field, Sources of Law: The Scope of Federal Common Law, 99 Harv L Rev 883 (1986).

${ }^{33}$ I list only recent cases with issues that fall within subjects often taught in federal courts courses: Brendale $v$ Confederated Bands and Tribes of Yakima Indian Nation, 109 S Ct 2994 (1989) (tribal authority to zone land owned by non-members on a reservation depends on history of diminution of tribal interests and threat to tribal political integrity), California v United States, 109 S Ct 2273 (1989) affirming by an equally divided Court 830 F2d 139 (9th Cir 1987) (extent to which United States waived sovereign immunity in litigation about a reservation's boundaries); Cotton Petroleum Corp v New Mexico, $109 \mathrm{~S} \mathrm{Ct}$ 1698 (1989) (state tax on oil and gas production by non-Indian lessees of tribal land not preempted); Mississippi Band of Choctaw Indians v Holyfield, 109 S Ct 1597 (1989) (under the Indian Child Welfare Act, state court lacks jurisdiction over children born off the reservation to members of the reservation who were domiciled there); Oklahoma Tax Comm v Graham, 109 S Ct 1519 (1989) (despite question of Indian tribe immunity from taxation, removal to federal court disallowed); Iowa Mut. Ins. Corp. $v$ La Plante, 480 US 9 (1987) (exhaustion of tribal court remedies required as a matter of comity in diversity case); California $v$ Cabazon Band of Mission Indians, 480 US 202 (1987) (preemption of state Bingo law on Indian tribal lands); Three Affiliated Tribes of Fort Berthold Reservation $v$ Wold Engineering, 476 US 877 (1986) (preclusion of state court jurisdictional scheme); South Carolina $v$ Catawba Indian Tribe, 476 US 498 (1986) (state statute of limitations applied to dispute over tribal land); National Farmers Union Ins. Cos. $v$ Crow Tribe, 471 US 845 (1985) (exhaustion of tribal remedies required before federal jurisdiction may be invoked); Montana States Tel. \& Tel. Co. v Santa Ana, 472 US 237 (1985) (authority of Secretary of Interior under Pueblo Lands Act); Kerr-McGee Corp $v$ Navajo Tribe, 471 US 195 (1985) (Secretary of Interior lacks control over Navajo Council's decisions on taxation).

${ }^{34}$ Richard H. Fallon, Jr., The Ideologies of Federal Courts Law, 74 Va L Rev 1141 (1988). See also Akhil Reed Amar, Law Story 102 Harv L Rev 688 (1989) (review of Bator, et al, Hart and Weschler's The Federal Courts and the Federal System (cited in note 16)). 
and federal governments.

In contrast to many of the states, ${ }^{35}$ Indian tribes are arguably truly distinct sovereigns, which did not cede sovereignty with the adoption of the Constitution but which lost most of it anyway. Exploration of the responses of federal courts - when individuals ask for federal protection from the tribal government, as in Santa Clara Pueblo, and when tribes claim intrusion by the state and federal governments - can inform contemporary discussions of the domain of the federal courts. How the United States government has treated Indian tribes and those in conflict with the tribes teaches us about the enormous power of the federal government. The capacity of the United States government to try to obliterate smaller "sovereigns" illuminates reasons to respect and maintain semi-sovereigns and demonstrates the complexity of the interaction and interdependence of "sovereigns" in the United States.

Before beginning my exploration of the richness of materials about Indian tribes for federal courts jurisprudence, three definitional comments are in order. First, a word about the choice of language, about my using the words "Indian tribes" rather than "Native Americans." While the phrase "Native American" helps to make the point that the United States was peopled prior to the arrival of European settlers, the words "Native American" may also suggest the similarity - and homogenization - of the experiences of a variety of "ethnic" groups in the United States. "Native Americans" might then be assumed to be similarly situated to "Italian Americans" or "Polish Americans." Using the words "Indian tribes" (or the name of a specific tribe) underscores the distinct political experiences of Indian tribes, conquered by the United States rather than entering the United States, as did waves of immigrants. Further, using the names of specific tribes underscores the diversity of interactions between the federal government and the many different Indian tribes.

Second, my purpose in this essay is to explore how learning about the history and treatment of Indian tribes helps illuminate the relationship between state and federal governments. This article is not an exploration of what the relationship between the federal government and the Indian tribes should be, of when causes of action should be implied from federal statutes, or of federal Indian

${ }^{35}$ While states are typically assumed to share a uniform history of equal participation in the forming of the Union, some of the states' "ratification" of the Fourteenth Amendment was obtained by coercion. See discussion at notes 124-30. See generally Eric Foner, Reconstruction: America's Unfinished Revolution (Harper \& Row, 1988). 
law in general. Indeed, while thinking about tribes may enrich conversations about the states and the federal government, thinking about the states may not be helpful to conversations about the tribes and the federal government. ${ }^{36}$ Blurring the lines between "state" and "Indian tribe" may obscure the political differences between the two "sovereigns." At least in theory, states have entered into a compact, called the United States Constitution, and willfully ceded powers to a central government. At least in theory, states participate via their representatives in Congress in the decisions of the national government. Such claims cannot be made, even in theory, for the Indian tribes, whose representatives neither signed the Constitution nor sit in Congress.

Third, a word about my occasional use of the word "we." The "we" here are those who have the capacity and authority to construct the boundaries of an academic discipline. As Barbara Herrnstein Smith has commented, the "recommendation of value represented by the repeated inclusion of a particular work in anthologies ... not only promotes but goes some distance toward creating the value of that work, as does its repeated appearance on reading lists, or its frequent citation or quotation by professors, scholars, critics, poets and other elders of the tribe; for all these acts have the effect of drawing the work into the orbit of attention of potential readers and, by making the work more likely to be experienced at all, they make it more likely to be experienced as 'valuable.' In this sense, value creates value." ${ }^{37}$ Hence, my objectives: to learn what has been drawn into the circle of value, what has been excluded, and what "we" can learn and should do in response.

\section{Creating the Boundaries of Jurisprudential Thought About the Federal Courts}

Self-conscious examination of the contents and boundaries of a given subject matter is by now a familiar activity. Literary critics dispute the existence and content of "great" literature, ${ }^{38}$ as we

${ }^{36}$ In a recent Supreme Court case, "[a]ll of the Indian tribes that . . f filed amicus curiae briefs addressing" the issue of whether tribes should be considered "states" for purposes of the Commerce Clause "uniformly [took] the position that Indian tribes are not States within the meaning of the Commerce Clause." Cotton Petroleum Corp v New Mexico, $109 \mathrm{~S} \mathrm{Ct}$ at 1715.

${ }^{37}$ Barbara Herrnstein Smith, Contingencies of Value: Alternative Perspectives for Critical Theory 10 (Harvard, 1988).

${ }^{33}$ Sandra M. Gilbert and Susan Gubar, The Madwomen in the Attic, ch 1, The Queen's Looking Glass: Female Creativity, Male Images of Women, and the Metaphor of 
come to understand that "the canonical work begins increasingly not merely to survive within but to shape and create the culture in which its value is produced and transmitted and, for that very reason, to perpetuate the conditions of its own flourishing." Olsen entitles a book Silences and dedicates it to "silenced people, ... [t] heir art, which still they made . . . anonymous, refused respect, recognition; lost."40 Issues are raised not only about who is heard and who is marginalized or silenced, but also about how perspective and experiences shape the creation of value. Psychologists note how the absence of women, as participants in or subjects of psychological studies, affects the resulting assumptions about hierarchies of moral development." In a similar vein, commentators about the federal courts have examined how experiences of living through the New Deal shaped the vision of the respective roles of the federal and state judiciaries. ${ }^{42}$

\section{A. A Course of Study}

A first step is to consider how the boundaries of federal courts' jurisprudence came to be delineated and whether cases about Indian tribes have always been excluded. Before engaging in "psychological imperialism"43 by assuming that my reality was the reality, I reviewed the books, written for teachers, students, and practitioners, that have shaped and defined the federal courts' orthodoxy. While teachers may choose not to discuss all the materials in a book or may add materials, books intended to be used in teaching a discipline provide a rough sense of what is understood to be within a discipline's domain.

The Business of the Supreme Court, written in 1928 by Felix Frankfurter and James M. Landis, is the contemporary landmark of the self-conscious treatment of the federal courts as a topic of study distinct from other areas of law. ${ }^{44}$ The authors claimed that

Literary Paternity 3-44 (Yale, 1979). Compare Allan Bloom, The Closing of the American Mind (Simon \& Schuster, 1987).

30 Smith, Contingencies of Value at 50 (cited in note 37).

10 Tillie Olsen, Silences dedication page (Delta-Seymour, 1978).

1 Carol Gilligan, In a Different Voice (Harvard, 1982).

12 Amar, 102 Harv L Rev at 700-10 (cited in note 34).

is A term I borrow from Catharine Hantzis, who explains that a person may assume that his or her reality is the reality that others experience as well. (Correspondence, fall 1988) (on file with the author).

"Felix Frankfurter and James M. Landis, The Business of the Supreme Court: A Study in the Federal Judicial System (MacMillan, 1928) ("Frankfurter and Landis") This book is described as "[t]he classic and indispensable account of the history of the federal judiciary acts" by the editors of the most recent edition of Hart and Wechsler's, The Fed- 


\section{"scant attention" had been paid to the development of the federal}

eral Courts and the Federal System at $30 \mathrm{n} 2$ (cited in note 16).

There are several earlier works on the federal courts. The list that follows includes those, from the nineteenth and early twentieth century, that have been preserved by the two law libraries in which I worked on this article. This list is not intended to be exhaustive but exemplary and, for federal courts fans, helpful. For works that predate Frankfurter and Landis, see Alfred Conkling, whose treatise went under a variety of names including, $A$ Treatise on the Organization and Jurisdiction of the Supreme, Circuit and District Courts of the United States 19 (Gould, Banks, 2d ed 1842) (Indian nations discussed as not being "foreign states" in reference to the original jurisdiction of the Supreme Court, but rather "domestic, dependent nations"); A Treatise on the Organization, Jurisdiction and Practice of the Courts of the United States 46 (W.C. Little, 3d ed 1856) (same discussion of Indian nations); A Treatise on the Organization, Jurisdiction and Practice of the Courts of the United States in Suits at Law 22-23 (W.C. Little, 5th ed 1870) (same reference to Indian nations); Stephen D. Law, The Jurisdiction and Powers of the United States Courts 10 (Little, 1852) (Indian tribes discussed as not being foreign states for purposes of federal court jurisdiction); Benjamin R. Curtis, Jurisdiction, Practice and Peculiar Jurisprudence of the Courts of the United States $18 \mathrm{n} 3$ (Little, Brown, 1880) (mentioning Cherokee Nation case, 30 US (5 Pet) 1 (1831)); Benjamin V. Abbott, A Treatise upon the United States Courts and their Practice vols I and II (Diossy, 1871) (vol II refers to a law giving "white persons" the burden of proof when contesting title with an Indian (at 125); and "Indians" as "competent witnesses" (at 136)); A. J. Peeler, A Treatise on Law and Equity as Distinguished and Enforced in the Courts of the United States (Swindells, 1883) (Indian treaties and citizenship discussed); Samuel T. Spear, The Law of the Federal Judiciary: A Treatise 180 (Baker, Voorhis, 1883) ("for the purpose of making treaties with them, these tribes have been recognized as States, in the general political sense they are not foreign States, and not States of the Union, and, as tribes, not citizens or subjects of either class of States . . . [t]heir status is that of dependent nations within the general jurisdiction of the United States."); Samuel A. Blatchford, General Rules of the Supreme Court of the United States (Banks \& Bros., 1884) (no index reference to Indian tribes); Erastus Thatcher, A Digest of Statutes, Equity Rules, and Decisions upon the Jurisdiction, Pleadings, and Practice of the Circuit Court of the United States (Little Brown, 1883) (several references to Indians and Indian country); A. H. Garland and Robert Ralston, A Treatise on the Constitution and Jurisdiction of the United States Courts vols I and II (T.\& J.W. Johnson \& Co, 1898) (several references to Indian territory and courts); Robert Desty, A Manual of Practice in the Courts of the United States (Bancroft Whitney, 9th ed, 1899), in 4 vols (several mentions of Indian in index); Howard M. Carter, The Jurisdiction of Federal Courts As Limited By the Citizenship and Residence of the Parties, (Little Brown, 1899) (no index reference to tribes); Charles Bunn, A Brief Survey of the Jurisdiction and Practice of the Courts of the United States (West, 1914) (no index reference to Indian tribes); Orlando F. Bump, The Title Judiciary in the Revised Statutes of the United States and The Rules Promulgated by the Supreme Court and Forms (Cushings and Bailey, 1881)(no index reference to Indian tribes); Roger Foster, A Treatise on Federal Practice vols I and II (Callaghan, 3d ed 1901) (reference to jurisdiction/Indians); John W. Dwyer, The Law and Procedure of United States Courts 32 (Wahr, 1901) (Indian tribes in index); Robert M. Hughes, Handbook of Jurisdiction and Procedure in United States Courts (West, 1904) (no index reference to Indian tribes); Robert M. Hughes, Handbook of Jurisdiction and Procedure in United States Courts 196 (West, 2d ed 1913) (references to jurisdiction and Indian land); C. L. Bates, Federal Procedure at Law, vols I and II (T.H. Flood, 1908) (Indian tribes discussed in reference to jurisdiction and citizenship); John C. Rose, Jurisdiction and Procedure of the Federal Courts (Matthew Bender, 2d ed 1922) (reference to Indian jurisdictional issues) (Matthew Bender, 3d ed 1926) (same references).

Other early books on the federal/state court systems include George C. Holt, The Con- 
judiciary's business since $1789,{ }^{45}$ and that, given the powers that the federal judiciary exercised, intense study was appropriate. ${ }^{46} \mathrm{Al}-$ though the book is titled "The Business of the Supreme Court," the subtitle is "A Study in the Federal Judicial System," ${ }^{47}$ and much of the subject matter reflects the subtitle. Chapters are devoted to the circuit courts and specialized courts as well as to the Supreme Court. The subject matter is wide-ranging, but the role of the federal courts vis-a-vis Indian tribes is not considered.

A second major marker of a distinct jurisprudence of federal courts is Felix Frankfurter's and Wilber G. Katz's (and later Frankfurter's and Harry Shulman's) Cases and Other Authorities on Federal Jurisdiction and Procedure, ${ }^{48}$ which was published in 1931 as a vehicle for teaching students about the federal courts. ${ }^{49}$

current Jurisdiction of the Federal and State Courts (Baker, Voorhis \& Co., 1888); John Shields, Federal Courts and Practice (Banks, 1912); and Charles P. Williams, Jurisdiction and Practice of the Federal Courts (F.H. Thomas, 1917), none of which focused upon the relationship between federal courts and Indian tribes. Shields does have a chapter on Territorial courts, in which mention is made of Indian Territory, and the five tribes, Cherokees, Creeks, Choctaws, Seminoles and Chickasaws, described as "separate nations." Shields, Federal Courts at 133. George F. Longsdorf, Encyclopedia of Federal Procedure (Callaghan, 1930) includes three categories about Indian Tribes (Indian Lands, Indian Reservations, and Indians); the 1939 supplement, edited by John M. Greenfield, substantially expands the discussion of Indians.

4s Frankfurter and Landis, at preface, vi (cited in note 44).

46 In the same year that the Frankfurter and Landis book was published, Armistead M. Dobie, then a law professor at the University of Virginia Law School, published a book entitled Handbook of Federal Jurisdiction and Procedure (West, 1928). Professor Dobie stated that he "had the practitioner primarily in mind" but hoped that law students would also find his work "useful." Id at v. Indians are mentioned in the book, in relationship to district court jurisdiction over allotment issues, id at 261-62, and in a discussion of the Congressional power to regulate commerce with the Indian tribes, id at 50-51.

${ }^{47}$ Frankfurter and Landis at 1 (cited in note 44).

18 Frankfurter and Katz (cited in note 16); Felix Frankfurter and Harry Schulman, Cases and Authority on Federal Jurisdiction and Procedure (Callaghan, rev ed 1937) ("Frankfurter and Schulman").

49 As mentioned in note 44 , several textbooks and treatises were already in use. The Frankfurter and Katz book was a casebook, rather than a treatise. Again, dependent upon what law libraries have saved, I have found only two earlier casebooks on the federal courts. In 1917, George W. Rightmire, a professor at Ohio State University College of Law, published Cases and Readings on the Jurisdiction and Procedure of the Federal Courts (W.H. Anderson, 1917). Professor Rightmire noted that, while the "traditional method" of teaching had been by lecture and text, the case method seemed "as highly desirable" for teaching federal jurisdiction as for other subjects. Id at v. Professor Rightmire excluded from his materials "the large special subjects: bankruptcy, admiralty and maritime jurisdiction and patents" on the ground that they receive "adequate treatment" elsewhere in the curriculum. Id. The book has no index, but neither its Table of Contents nor List of Cases makes reference to major Indian cases.

In 1926, Harold R. Medina, then a professor at Columbia University Law School, published Cases on Federal Jurisdiction and Procedure (West, 1926). In his Preface, Professor Medina stated that, given the "substantial expansion and extension of the federal judicial 
In the introduction to the first edition, the authors argued for a place in the curriculum for a course on federal jurisdiction and procedure, as distinct from federal "practice." The authors sought to provide a curriculum appropriate to a "university law school," the courts and the relationships between federal and state courts - provided history, doctrine, and political science worthy of law schools. ${ }^{52}$ The authors chose to exclude the " 'federal specialties' admiralty, bankruptcy, the federal criminal law, Indian land litigation, patents" - from their book, because the jurisdictional and procedural problems identified with these subjects were "so intimately connected with their substantive law" that these fields were better left to "specialists." W3 What remained within the canon were discussions of categories familiar by virtue of contemporary conversations: the exploration of "case or controversy" requirements; the power of the federal courts to make common law; the jurisdictional boundaries described by diversity; federal questions; habeas corpus; and the appellate and original jurisdiction of the Supreme Court. ${ }^{54}$

Frankfurter and Katz were evidently hoping to influence the choice of teaching materials used in on-going courses in law

power," lawyers need to have a "thorough understanding of the federal judicial system." Id at iii. Professor Medina included some "details of practice," but his goal was to lay a "solid foundation of principle and precedent." Id. The Index does not refer specifically to Indian tribes and one of the cases included mentions the Cherokee Nation case, 30 US (5 Pet) 1 (1831). Id at 610 .

${ }^{\text {so }}$ Frankfurter and Katz at $\mathrm{v}$ (cited in note 16) (emphasis in the original). Statement repeated in Frankfurter and Schulman (cited in note 48).

s1 Frankfurter and Katz at v (cited in note 16).

52 Id at viii-ix.

B3 Id at $x$ n 1 . In the 1931 edition, the specialties of "admiralty," "federal common law, crimes," and "patent" were separately indexed at 755,760 , and 763 , respectively. In the 1937 edition, all the "specialties" save "Indian law" were accorded separate headings in the index (admiralty, id at 817; bankruptcy, id at 818; federal common law crimes, id at 822 , and patent, id at 828).

st Frankfurter and Katz (cited in note 16), Table of Contents at ix, and the chapters noted therein. In the 1931 edition of the casebook, the major categories were: "case and controversy," "legislative courts," "law applied in the federal courts," "jurisdiction" in the trial courts, concurrent jurisdiction; appellate jurisdiction, and Supreme Court jurisdiction. Id at ix-x. For discussion of how, after the early 1930s, Frankfurter aided in the creation of doctrinal limits on federal courts' jurisdiction, see Steven L. Winter, The Metaphor of Standing and the Problem of Self-Governance, 40 Stan L Rev 1371, 1417-52 (1987). For those who enjoy federal courts trivia, note that Herbert Wechsler did a book review of the Frankfurter and Katz materials. Herbert Wechsler, Cases and Other Authorities on Federal Jurisdiction and Procedure, 32 Colum L Rev 774 (1932). ("[T] grand performance [but the book's] weakness [is that it] raises the vital questions but it does not attempt to answer them, nor to provide the materials for doing so"). 
schools. The third American Association of Law Schools (AALS) directory, which appeared in 1924, listed a course in "federal jurisdiction and procedure," "federal jurisdiction." tory, ${ }^{57}$ Felix Frankfurter (along with several others) ${ }^{58}$ was described as having taught a federal jurisdiction course for more than ten years ${ }^{58}$-indicating that in the 1920 s and 1930 s federal courts courses were offered at several law schools. ${ }^{60}$

The contemporary conception of a course about the federal courts took shape in 1953 when Henry Hart and Herbert. Wechsler published The Federal Courts and the Federal System." "Hart.

ss My reference to the third AALS directory again reflects library holdings. The AALS was founded in 1900 but it did not have a permanent office until 1963; its files moved from officer to officer. The AALS was incorporated in 1971 and its current files date from 1973. A committee has been appointed to work on the Association's archives. Conversation with Betsy Levin, Executive Director of the AALS (Nov. 23, 1988).

se Note that in 1986 the AALS added "sections" on both federal courts and Native American Law. See Association of American Law Schools, Directory of Law Teachers, 198687 932, 976 (West, 1986).

s7 That volume, in so far as I can ascertain, was the first one to list teachers by subject matter. See Association of American Law Schools, Directory of Teachers in Member Schools 139-169 (West, 1931) ("Directory"). Before that, teachers were listed alphabetically, with the courses taught listed after each name.

${ }^{88}$ AALS, 1931 Directory 153 (cited in note 57). Included in the list of those teaching "Federal Jurisdiction and Procedure" for more than ten years were: Edwin C. Brandenburg (George Washington); Armistead Mason Dobie (Virginia); Ira Samuel Flory (Louisiana State); Felix Frankfurter (Harvard); Jason E. Payne (South Dakota); and John Weld Peck (Cincinnati). Id. As of 1915, John Wurts was described as teaching "Federal Practice" at Yale Law School. Notes and Personals, 4 Am L Sch Rev 51 (1915). In 1904, Stuart MacKibbin at Northern Indiana Law School was teaching a course called "Federal Practice." 1 Am L Sch Rev 242 (1904). See also Charles W. Needham, Schools of Law: The Subjects, Order and Method of Study, 21 Reports of the ABA 615, 627 (1898) (advocating a course on federal jurisdiction in the third year of law school).

s9 AALS, 1931 Directory at 153 (1931) (cited in note 57); see also 1932 Directory at 157.

-0 According to another book review of the Frankfurter and Katz book, "about thirty" law schools belonging to the AALS included a federal jurisdiction/courts course among their offerings. Charles T. McCormick, Book Review, 80 U Pa L Rev 472, 474 (1931). In the 1930s and 1940s, other books on federal courts were published, among them Mahlon E. Wilson's Federal Courts (Grocer, 1930) (lectures at the Law Department of the University of Utah; no mention of major Indian cases); W.S. Simkin and Alfred John Schweppe, Simkins Federal Practice (Law Co-op, rev ed 1934) (Indians referenced for allotment jurisdiction); Robert Jennings Harris, The Judicial Power of the United States (LSU, 1940) (Indian tribes not mentioned in index); and George Foster Longsdorf, Cyclopedia of Federal Practice, Civil and Criminal (Callaghan, 1928, with supp, 1939) (8 vol plus 1939 Supplement) (Indian tribes discussed in relation to jurisdictional issues).

${ }^{61}$ Cited in note 16. A few other casebooks predated this one but were focused more on procedure and federal jurisdiction than on the "federal system." See Charles T. McCormick and James Chadbourn, Cases and Materials on Federal Courts (Foundation, 1946) (because the federal court structure had changed a good deal over the past half century, the authors stated that an "ordered reconsideration of the whole structure seems long overdue." Id at ix. 
and Wechsler" is an important touchstone for what federal courts' jurisprudence has been from the 1950 s to the present. In 1953, Hart and Wechsler followed the choice made by Frankfurter, Katz, and Shulman in the 1930s; Indian tribe materials were not listed separately in the book's index. ${ }^{62}$ Unlike Frankfurter and his coauthors, however, Hart and Wechsler brought the "federal specialties" of admiralty, bankruptcy, and patent in from the cold; they were all listed as within the framework of "The Federal Courts and the Federal System."

Since the 1950s, many have written materials for the subject matter denominated "federal courts", "federal jurisdiction", and the "federal system". Most of the books refer hardly at all or only in notes to Indian tribe cases. ${ }^{64}$ The silence has not been complete; a few books have made references to federal treatment of Indian tribes. ${ }^{65}$ In general, however, materials about Indian tribes are not part of the federal courts' canon.

In the acknowledgments, they credited "those who have broken the trails which we follow Medina, Frankfurter, Dobie." (Id at xi); Armistead Dobie and Mason Ladd, Cases and Materials on Federal Jurisdiction and Procedure (West, 1940); Ray Forrester, ed, Dobie and Ladd: Cases and Materials on Federal Jurisdiction and Procedure (West, 2d ed 1950).

${ }_{62}^{62}$ In the 1953 edition, Indians do not appear as a category, but under "legislative courts" reference is made to the "Choctaw and Chickasaw Citizenship court" at 1436. In the 1973 edition of Hart and Wechsler by Paul M. Bator, Paul J. Mishkin, David L. Shapiro, and Herbert Wechsler, (Foundation, 2d ed 1973) the index does make a reference to "Indians," and the topics listed are "[e]ligibility for diversity jurisdiction" and "[j]usticiability of political questions related to" id at 1645. Reference is also made to "Indian lands," with the topic listed as including "validity of Congressional allotment acts," at 1645, and "Indian Claims Commission," including "Indian claims against the US," id at 1645. In the 1988 Hart and Wechsler (cited in note 16), neither Native American nor Indian tribes is a category in the index. See pages 1890 and 1892 . Indians are listed as a subcategory under political questions at 1893.

63 1953 edition - admiralty at 1423, bankruptcy at 1424, patent at 1438; 1973 edition - admiralty at 1631, bankruptcy at 1633, patent at 1649; 1988 edition - admiralty at 1879 , bankruptcy at 1880 , patent at 1893 . Federal criminal law continues not to receive distinct treatment.

64 See, for example, the recent editions of David P. Currie, Federal Courts: Cases and Materials (West, 3d ed 1982); Ray Forrester and John E. Moye, Cases and Materials on Federal Jurisdiction and Procedure (West, 3d ed 1977); Peter W. Low and John C. Jeffries, Jr., Federal Courts and the Law of Federal-State Relations (Foundation, 1987) ("Low and Jeffries"); Charles T. McCormick, James H. Chadbourn, and Charles A. Wright, Cases and Materials on Federal Courts (Foundation, 8th ed 1988); Martin Redish, Cases, Comments and Questions on Federal Courts (West, 2d ed 1989); Charles A. Wright, Federal Courts: Cases and Materials (Foundation, 1986).

6s See the 1973 edition of Hart and Wechsler for index listing on Indian tribes (cited in note 62); Howard P. Fink and Mark V. Tushnet, Federal Jurisdiction: Policy and Practice 258 (Michie, $2 \mathrm{~d}$ ed 1987) ("Fink and Tushnet"). 


\section{B. Premises of the Law of Federal Courts}

Several of the current federal courts casebooks ${ }^{66}$ begin with Marbury $v$ Madison, ${ }^{67}$ which is used to state basic principles: that the government of the United States is one of "powers limited"; that the Supreme Court holds the power to decide when other branches of the federal government have unconstitutionally "transcended" their powers; and that the Constitution is the repository of statements of the powers and limits of the federal government. ${ }^{68}$ Of course, the matters of "powers limited" is much more complex, as each account of the federal courts' "story" quickly develops. For example, when considering the power of the Congress over the jurisdiction of the federal courts, questions soon emerge about the breadth of authority granted in Article III to the Congress. ${ }^{69}$ Congress is often said to have "plenary power" over the federal courts' jurisdiction..$^{70}$ But not quite. Most commentators assume that a law that provided jurisdiction in the federal courts for white citizens but not for blacks would be unconstitutional - not because it violated the text of Article III, but because another part of the Constitution, the Bill of Rights, constrains congressional action. ${ }^{71}$

${ }^{68}$ See, for example, Hart and Weschler's Federal Courts, 3d ed at 72 (cited in note 16); Low and Jeffries at 1 (cited in note 64); Currie, Federal Courts: Cases and Materials 19 (cited in note 64). Compare Fink and Tushnet (cited in note 65) which begins with a discussion of the "allocation of power between state and federal courts." Id at 3-22.

${ }^{67} 5$ US (1 Cranch) 137 (1803).

${ }^{68}$ Marbury 5 US (1 Cranch) at 176. ("The powers of the legislature are defined and limited; and that those limits may not be mistaken, or forgotten, the constitution is written. ... The distinction between a government with limited and unlimited powers is abolished, if those limits do not confine the persons on whom they are imposed ...").

${ }^{60}$ Ex Parte McCardle, 74 US (7 Wall) 506, 514 (1869) ("We are not at liberty to inquire into the motives of the legislature. We can only examine its power under the Constitution; and the power to make exceptions to the appellate jurisdiction of this court is given by express words"); Sheldon v Sill, 49 US (8 How) 441,449 (1850) (“[H]aving a right to prescribe, Congress may withhold from any court of its creation jurisdiction of any of the enumerated controversies").

${ }^{70}$ See Leonard G. Ratner, Congressional Power Over the Appellate Jurisdiction of the Supreme Court, 109 U Pa L Rev 157, 158 (1960); Henry M. Hart, Jr., The Power of Congress to Limit the Jurisdiction of Federal Courts: An Exercise in Dialectic, 66 Harv L Rev 1362 (1953). But see Robert N. Clinton, A Mandatory View of Federal Court Jurisdiction: A Guided Quest for the Original Understanding of Article III, $132 \mathrm{U}$ Pa L Rev 741, 796, 840-55 (1984).

"See Sager, 95 Harv L Rev 17, 26-27 (cited in note 17) (a federal "court is obliged not to participate in unconstitutional conduct, and . . . a restriction [based on race, religion, or political affiliation] makes fidelity to that obligation impossible."). See also Clarke v United States, 705 F Supp 605, 612 (D DC 1988) ("The authority retained by Congress . . is ... as broad as Congress' plenary power to legislate for the District, but that authority itself is not limitless. . . . [T] original). 
Constitutionality is at the heart of discussions of the federal courts. $^{72}$ From the principle of limited governmental powers constrained by constitutional commitment (if not always by the text itself), a problem arises: how to explain and rationalize the growth of national powers in the context of a history of dual sovereignty, of a government founded on the idea that the states have consented to some form of simultaneous yet non-identical power-holding by state and federal governments. The recurring questions are: Who - the federal government or the states - gets to decide what issues? What kind of deference is owed by federal courts to the state courts? As federal courts' jurisprudence emerged during the New Deal era, scholarship and course materials reflected some ambivalence toward the federal courts. At once supportive of nationalization but wary of expansive federal court activity, the 1953 Hart and Wechsler casebook underscored both the unity of the federal court system and the importance of the state courts. As Akhil Amar has described, the 1953 version provided a "modest role" for the federal courts, both in their relationship to other branches of the federal government and in their relationship to the state courts. ${ }^{73}$

The changing perception of the federal courts in the 1960s during the civil rights era required some revision of the New Deal understandings. For many "children of the 1960s," the federal courts were special, populated by admirable spokespersons of national norms of equality and tolerance - heroes who vindicated the promise of the Bill of Rights. A new generation of scholars claimed a distinctive mission for the federal courts. ${ }^{74}$ Richard Fallon's recent article captures the conversation between those shaped by the experiences of the New Deal and those shaped by the civil rights revolution of the 1960s. Fallon describes "two models of judicial federalism." He denominates one as "Federalist," rooted "in a theory of the understanding that surrounded the framing and ratification of the original Constitution in 1787 and $1788 \ldots$. [and out of which comes an] interpretative framework [in which] states emerge as sovereign entities against which federal courts should exercise only limited powers, and state courts, which are presumed

72 In symbolic as well as textual terms. See Thomas C. Grey, The Constitution as Scripture, 37 Stan L Rev 1, 17-20 (1984); Sanford Levinson, Pledging Faith in the Civil Religion; Or, Would You Sign the Constitution?, 29 Wm \& Mary L Rev 113 (1987).

${ }^{73}$ Amar, 102 Harv L Rev at 698 (cited in note 34).

74 See Burt Neuborne, The Myth of Parity, 90 Harv L Rev 1105 (1977); Owen M. Fiss, Dombrowski, 86 Yale L J 1103 (1977); Amar, 102 Harv L Rev 688 (cited in note 34). 
to be as fair and competent as federal courts, stand as the ultimate guarantors of constitutional rights." In contrast, the "Nationalist model ... emphasizes the vast reordering of federal relations inaugurated by the Civil War and Reconstruction ... [from which emerge] its premises that state sovereignty interests must yield to the vindication of federal rights and that, because state courts should not be presumed as competent as federal courts to enforce constitutional liberties, rights to have federal issues adjudicated in a federal forum should be construed broadly."76

Efforts to encapsulate the issues of federal courts' jurisprudence as national versus state control leave out some concerns that are, for me, of compelling importance. Current political and social issues make state sovereignty and limited federal governmental powers increasingly tenuous premises. The federal and state governments are profoundly interconnected, as federal statutes provide for incentive grants, conditional grants, and joint welfare distribution programs. ${ }^{77}$ Delineations between the branches of the federal government are also not sharp, as a rigid separation of powers doctrine is rejected in favor of a less formalistic and more fluid model. ${ }^{78}$ The environmentalists warn about acid rain and toxic waste, and homeless individuals migrate from place to place in search of warmth and shelter. National programs, national norms, and national environmental risks all challenge the relevance of the geographic and political boundaries of states.

The task for federal courts' jurisprudence is to understand what might be meant by a claim of allegiance to more than one sovereign and what meaning, if any, inheres in the idea of states as "sovereigns." In an array of circumstances, federal courts' jurisprudence must question whether shared and concurrent jurisdiction remains viable and must explore whether to embrace or resist

${ }^{7 s}$ Fallon, $74 \mathrm{Va} \mathrm{L}$ Rev at 1143-44 (cited in note 34).

${ }^{78}$ Id at 1144-45 (footnotes omitted).

77 See generally Lewis B. Kaden, Politics, Money, and State Sovereignty: The Judicial Role, 79 Colum L Rev 847 (1979); Richard B. Stewart, Federalism and Rights, $19 \mathrm{Ga} \mathrm{L} \mathrm{Rev}$ 917 (1985); John E. Chubb, The Political Economy of Federalism, 79 Am Pol Sci Rev 994 (1985). See also Herbert Wechsler, The Political Safeguards of Federalism: The Role of the States in the Composition and Selection of the National Government, 54 Colum L Rev 543 (1954).

${ }^{78}$ Mistretta v United States, 109 S Ct 647 (1989) (sentencing guidelines, formulated with judicial participation, do not violate separation of powers); Morrison v Olson, $108 \mathrm{~S} \mathrm{Ct}$ 2597 (1988) (judicial role in appointing special prosecutor does not violate separation of powers).

78 See Andrzej Rapaczynski, From Sovereignty to Process: The Jurisprudence of Federalism after "Garcia", 1985 S Ct Rev 341. 
the pressures towards nationalization and homogenization. Are the states really coherent descriptions of viable political entities, or are they a fiction left over from an earlier era? ${ }^{80}$ Will and should the federal government tolerate sustained deviation from its norms? Are the forces of centralization and assimilation so great that the only laws that matter, ultimately, are national laws? Should the country strive to have a central government (with some measure of decentralization or delegation) or try to preserve some form of distinction between governments and encourage multiple sovereignties, multiple court systems, and multiple norms? While some federal courts' scholars address some of these issues in the context of state and federal relations, ${ }^{81}$ the law about Indian tribes helps underscore the centrality of these questions for federal courts' jurisprudence and helps to suggest some of the kinds of responses available.

\section{The Indian Tribes' Relationship to the United States}

I have had the opportunity to discuss the issues raised in this paper with many people. I have learned that, at least within the legal academy, a common perception is that federal Indian law is complex, foreign, very different, and thus an area set aside for "experts" alone. This essay is an effort to demonstrate that one need not know "everything" to speak a little, that just as those of "us" (within the legal academy) who are not economists, philosophers, political scientists, or feminist theorists integrate insights from economics, philosophy, political science and feminist theory, we can also integrate an area of law that challenges, admittedly and interestingly, some of the rules we take for granted.

Since the starting point for federal courts' jurisprudence is the Constitution, that is an appropriate place to begin a brief overview of federal Indian law. The Constitution refers explicitly in three places to Indians. ${ }^{82}$ First, Indians "not taxed" are excluded for

${ }^{80}$ See Aviam Soifer, Truisms That Never Will Be True: The Tenth Amendment and the Spending Power, 57 U Colo L Rev 793 (1986).

${ }^{81}$ See especially the rich set of writings generated in the wake of National League of Cities v Usery, 426 US 833 (1976), and Garcia v San Antonio Metro. Transit Auth., 469 US 528 (1985), many of which are explored in Deborah Jones Merritt, The Guarantee Clause and State Autonomy: Federalism for a Third Century, 88 Colum L Rev 1 (1988); in Rapaczynski, 1985 S Ct Rev 341 (cited in note 79); and in Federalism and the Constitution: A Symposium on Garcia (Advisory Comm on Intergovtl Relations, July 1987).

${ }_{82}$ Charles Wilkinson states that tribes "were considered only six times in the Constitution." In addition to counting the two references to apportionment and the Indian commerce clause, he refers to Art I, $\S 8, \mathrm{cl} 11$ (Congress' war-making powers); Art VI, cl 2 
purposes of apportioning members of the House of Representatives among the states. ${ }^{83}$ Second, the Constitution gives Congress the power to regulate commerce with the Indian Tribes. ${ }^{84}$ Third, the Fourteenth Amendment reiterates the exclusion of "Indians not taxed" for purposes of apportionment. ${ }^{85}$ In addition to specific references, the constitutional grants of power to the Congress to make regulations governing the territories ${ }^{86}$ and to the President to make treaties $^{87}$ have been read as empowering those branches to relate to Indian tribes. ${ }^{88}$

To the extent Indian tribes are discussed in the Constitution, they seem to be recognized as having a status outside its parameters. Indian tribes are treated as entities with whom to have commerce and to make treaties. The tribes also seem to be freed from the taxing power of either the state or federal governments. ${ }^{89}$ The constitutional references fit with the fact that the Indian tribes did not take part in the Constitutional Convention and did not join in the federation of powers. As many scholars have discussed, one might describe the relationship between the Indian tribes and the United States as that between two sovereigns, and locate the relevant legal discourse as that of international law. ${ }^{90}$ Thus, one might

(treaties as supreme law); and Art II, § 2, $\mathrm{cl} 2$ (presidential treaty-making powers). Charles F. Wilkinson, Civil Liberties Guarantees when Indian Tribes Act as Majority Societies: The Case of the Winnebago Retrocession, 21 Creighton L Rev 773, 774-75 (1988).

${ }^{83}$ US Const, Art I, § 2, cl 3.

84 US Const, Art I, § 8, cl 3.

ss US Const, Amend XIV, § 2.

se US Const, Art IV, $\S 3$, cl 2.

87 US Const, Art II, $\$ 2$, cl 2.

${ }^{88}$ Using these constitutional bases for Indian tribe/federal government relations is difficult for several reasons. First, during the treaty-making era, much of the treaty drafting was done by federal officials and some have suggested that those who signed on behalf of Indian tribes were not authorized to do so. Second, treaties were not made with all tribes, but federal control has extended over all the tribes. Third, even before twentieth century expansion of the "commerce clause" interpretations, the Supreme Court upheld broad congressional powers over Indian tribes. See, for example, Indian Appropriations Act of March 3, 1885, 23 Stat 385; upheld in United States $v$ Kagama, 118 US at 378-80. Finally, claims of federal power based upon the authority to govern the "territories" depend upon whether Indian country is properly construed as federal "territory." See generally Barsh and Henderson, The Road at ch 7 (cited in note 22).

B9 Barsh and Henderson, The Road at ch 4 (cited in note 22). On continuing "outside" status, see Barsh and Henderson, The Road at prologue; Robert A. Williams, Jr., The Algebra of Federal Indian Law: The Hard Trail of Decolonizing and Americanizing the White Man's Indian Jurisprudence, 1986 Wisc L Rev 219. Charles Wilkinson argues that the "Constitution recognizes a third source of domestic sovereignty - the governmental status of American Indian tribes." Wilkinson, 21 Creighton L Rev at 774 (cited in note 82). Professor Wilkinson does, however, note the "Constitution's vague treatment of Indian tribes." Id at 775 .

${ }^{\circ 0}$ See, for example, Jill Norgren, Protection of What Rights They Have: Original Prin- 
conclude, Indian tribes are not part of the federal system, and hence, are appropriately not part of a discussion of federal courts jurisprudence.

However, in 1871, the federal government halted its treatymaking with the Indian tribes. By the end of the nineteenth century, the lack of participation by the Indian tribes in the federation process ceased to reflect the distance between the federal government and the Indian tribes, at least in so far as the federal government was concerned. Congress regulated the internal affairs of Indian tribes and the Supreme Court upheld such regulation as within Congress's power to protect its "wards." Although Chief Justice John Marshall cast the emerging claim of federal plenary power over Indian tribes in terms of the right of "discovery,"92 the uncomfortable truth (referred to in several Supreme Court opinions $^{93}$ ) is that the "right," if that term is apt, derived from conquest. The United States had the physical power and used it.94 By virtue of force, the federal government took land, removed people from their homes, attempted to dissuade them from observing their customs, and imposed its rule. ${ }^{95}$ The United States had official policies aimed at "relocation" and "termination" of Indian

ciples of Federal Indian Law, 64 ND L Rev 73 (1988). For discussion of the pre-colonial relationships that underscore the historical basis of an international law approach, see Robert N. Clinton, Proclamation of 1763, Colonial Prelude to Two Centuries of Federal-State Conflict over the Management of Indian Affairs (November, 1988) (manuscript on file with the University of Chicago Law Review). See also Barsh and Henderson, The Road at ch 4 (cited in note 22).

91 United States v. Kagama, 118 US at 383. The Kagama Court spoke of the ward/ guardian relationship between Indian tribes and the federal government and the federal government's "protection" of the tribes from the states.

${ }^{92}$ Johnson $v$ M'Intosh, 21 US (8 Wheat) 543, 573 (1823). Compare Joseph Story, $A$ Brief Exposition of the Constitution of the United States, at 14-15 (Hilliard, Gray \& Co, 1834) ("it seems difficult to perceive, what ground of right any discovery could confer").

${ }_{83}$ "Every American schoolboy knows that the savage tribes of this continent were deprived of their ancestral ranges by force and that, even when the Indians ceded millions of acres by treaty in return for blankets, food and trinkets, it was not a sale but the conquerors' will that deprived them of their land." Tee-Hit-Ton Indians $v$ United States, 348 US 272, 289-90 (1955) (Reed, for the Court); "discovery gave an exclusive right to extinguish the Indian title of occupancy, either by purchase or by conquest ... [c]onquest gives a title which the courts of the conqueror cannot deny ...." Johnson $v$ M'Intosh, 21 US (8 Wheat) 543, 587-88 (1823) (Marshall, for the Court); "power, war, conquest, give rights, which, after possession, are conceded by the world." Worcester v Georgia, 31 US (6 Pet) 515, 543 (1832).

94 For more on jurisdiction by violence, see Robert M. Cover, Owen M. Fiss, and Judith Resnik, Procedure 1350-62 (Foundation, 1988) (discussing United States v Toscanio, 500 F2d 267 (2d Cir 1974)), and Robert Cover, Violence and the Word, 95 Yale L J 1601 (1986).

${ }^{25}$ See generally Vine Deloria, Jr. and Clifford M. Lytle, American Indians, American Justice ch 1 (U Tex, 1983).

${ }^{96}$ In 1835 , the United States government required the Cherokee Nation to move from the South to the West. This trek came to be known as the "trail of tears" because thousands 
tribes, yet no document authorized that breadth of federal control. ${ }^{98}$ No consent of the governed (not even weak versions of consent theory) can be offered in support of the authority exercised by "the federal system" over Indian tribes.

Supreme Court case law repeatedly creates and then recognizes the enormity of the "plenary" federal power over the Indian tribes. ${ }^{99}$ Take, for example, a statement quoted in a recent Supreme Court case: " '[A]ll aspects of Indian sovereignty are subject to defeasance by Congress." "100 Ordinary constitutional exegesis

perished as they moved west of the Mississippi. Other Eastern tribes followed thereafter. See Treaty with the Choctow Indians (at Dancing Rabbit Creek) in Francis Paul Prucha, ed, Documents of the United States Indian Policy 53 (U Nebraska, 1975) (Choctow removal).

${ }^{87}$ In the 1950s, the federal government "terminated" its recognition of the sovereignty of several tribes. HR Con Res 108, 67 Stat B132 (1953). In some instances, courts have held that such "termination" was illegal. See Smith v United States, 515 F Supp 56, 58 (N D Cal 1978). For a list of many of the terminated tribes and discussion of termination, see Wilkinson, 21 Creighton L Rev at 777 (cited in note 82).

${ }^{88}$ Some Indian tribes ceded some powers to the federal government-via treaties and via constitutions and bylaws written under the Indian Reorganization Act of 1934 (see notes 150-53, 184-96 and accompanying text). Neither kind of document supports the breadth of actual congressional intervention. For a discussion of how to create constitutionally-based limits on federal powers, see Robert $\mathrm{N}$. Clinton, Isolated in Their Own Country: A Defense of Federal Protection of Indian Autonomy and Self Government, 33 Stan L Rev 979 (1981). Clinton argues that the framers of the Constitution intended to give Congress power to make treaties with Indians but not to control intra-tribal affairs. Clinton does note that the "Indian commerce clause" could be read as expansively as the "interstate commerce clause." Id at 997. Under such a reading, the constitutional limits on congressional power over Indian tribes may be more formal than real.

${ }^{9}$ See Ball, 1987 Am B Found Res J at 46-59 (cited in note 21); Nell Jessup Newton, Federal Power over Indians: Its Sources, Scope, and Limitations, 132 U Pa L Rev 195, 19798, 207-28, 236 ("plenary power" doctrine has been narrowed since the 1930s, but limits on congressional power still unclear); Comment, Inherent Indian Sovereignty, 4 Am Indian L Rev 311, 316-20 (1976) (by Jessie D. Green and Susan Work). For debate about the utility for Indian tribes of Congressional "plenary power," see Robert Laurence, Learning to Live with the Plenary Power of Congress Over the Indian Nations, 30 Ariz L Rev 413 (1988) (replying to Williams, 1986 Wisc L Rev 219 (cited in note 89)); Robert A. Williams, Jr., Learning Not to Live with Eurocentric Myopia: A Reply to Professor Laurence, 30 Ariz L Rev 439 (1988); Robert Laurence, On Eurocentric Myopia, the Designated Hitter Rule and "The Actual State of Things", 30 Ariz L Rev 459 (1988). For analysis of how the "mythology" of "plenary power" grew and the harm that it does, see Robert A. Williams, Jr., Emergence of a National Indian Policy: Parens Patriae and Indian Tribal Sovereignty, (manuscript on file with the University of Chicago Law Review).

${ }^{100}$ National Farmers Union Ins. Cos. $v$ Crow Tribe, 471 US 845, 851 n 10 (1985), quoting Escondodo Mutual Water Co. v LaJolla Bands of Mission Indians, 466 US 765, $788 \mathrm{n}$ 30 (1984). See also Wallace v Adams, 204 US 415, 423 (1907) (Congress has plenary power over tribal membership), and cases cited by Ball, 1987 A B Found Res J at 49-58 (cited in note 21), and by Williams, 30 Ariz L Rev at 445-47 (cited in note 99). Recently, the Supreme Court has begun to forge a doctrine of limitations on Congress's plenary powers, although the contours are still ill-defined. See, for example, Delaware Tribal Business Comm. $v$ Weeks, 430 US 73, 84 (1977) (plenary power "does not mean that all federal legislation concerning Indians is . . immune from judicial scrutiny"); United States v Tillamooks, 329 
would oblige the Court then to make reference to some provision in the Constitution, or other documents such as treaties, by which the Indian tribes ceded powers to the central government. Moreover, ordinary constitutional exegesis would also describe federal powers as having boundaries, albeit sometimes vague ones. Even when constitutional theorists believe in the plenary power of one branch of the federal government in particular instances, reference is made to constraints, to power that is checked - either by political recall, dependence upon other branches for implementation of the decisions made, or by other constitutional guarantees. ${ }^{101}$ Recall the example mentioned above, that Congress has "plenary power" over the federal courts' jurisdiction. While federal courts scholars are used to hearing that claim, they are similarly used to explaining that "plenary power" always comes with the caveat: but see the Bill of Rights. ${ }^{102}$

Not so for Congress's power over the Indian tribes. There is no "but see the Bill of Rights" because the United States Supreme Court has held that the Bill of Rights has little application to Indian law. Members of Indian tribes cannot make Bill of Rights claims against their tribes, ${ }^{103}$ and Indian tribes are not protected by the Bill of Rights from federal decisions. For example, the Supreme Court has stated that "Indian occupancy, [on land] not specifically recognized by action authorized by Congress, may be extinguished by the [federal] Government without compensation."104

US 40, 54 (1948) (plurality opinion) ("The power of Congress over Indian affairs may be of a plenary nature; but it is not absolute"). For commentary raising concerns about the source and nature of federal judicial power over Indian tribes, see Ball, 1987 Am Bar Found Res J at 46-61 (cited in note 21). See also William C. Canby, Jr., The Status of Indian Tribes in American Law Today, 62 Wash L Rev 1, 19-22 (1987).

101 See Morrison v Olson, 108 S Ct 2597, 2629 (1988) (Scalia dissenting) (presidential powers to prosecute are exclusive but are checked by political scrutiny).

${ }^{102}$ See, for example, Sager, 95 Harv L Rev at 26-27 (cited in note 17). As Sager discusses, in addition to the "external" constraint imposed by the Bill of Rights, many theorists believe that Article III itself limits Congress's authority over federal court jurisdiction.

Another area of law in which "plenary power" may not be constrained by Bill of Rights protections is immigration law. See Peter $\mathrm{H}$. Schuck, The Transformation of Immigration Law, 84 Colum L Rev 1, 18-24 (1984). See generally and Peter H. Schuck and Rogers M. Smith, Citizenship without Consent (Yale, 1985).

${ }^{103}$ See Talton v Mayes, 163 US 376, 384 (1896); Santa Clara Pueblo, 436 US at 56. But see Colliflower $v$ Garland, 342 F2d 369 (9th Cir 1965) (applying Fifth Amendment due process protections to individual challenging tribal court action). As discussed, the Indian Civil Rights Act of 1968, 25 USC $\S \S 1301-1303$, creates statutory rights that are akin to much of the Bill of Rights and that Indians may invoke against their tribe. See note 3 and accompanying text.

${ }^{104}$ Tee-Hit-Ton Indians $v$ United States, 348 US 272, 288 (1955). According to that case, aboriginal Indian land is not "property" for Fifth Amendment purposes absent a clear 
As William Canby has recently explained, "the sovereignty of the tribes is subject to exceptionally great powers of Congress to regulate and modify the status of the tribes."10s

Moreover, in contrast to the assumption that, whatever Congress might be able to do about the jurisdiction of the federal courts, Congress surely could not use race as a jurisdictional category, ${ }^{106}$ jurisdiction in cases involving Indians is jurisdiction based in part upon race. The status of "Indian" is defined, to some extent and in some contexts, by virtue of the quantum of "Indian blood" that an individual has. ${ }^{107}$ Federal courts have jurisdiction over certain crimes committed in Indian country that involve "Indians,"108 and Indian tribal courts have criminal jurisdiction over member "Indians" but not over non-Indians. ${ }^{109}$

Even in an era when many are comfortable with penumbras of constitutional interpretation, ${ }^{110}$ it is difficult to "interpret" the Constitution in a manner that supports the proposition that the Congress has "plenary" control over intra-Indian tribe activities 111 or that Congress can make or sanction racially-based jurisdictional

congressional statement that Indian land is Indian land. Id at 278-91. See United States $v$ Sioux Nation of Indians, 448 US 371, 415 n 29 (1980) ("Of course, it has long been held that the taking by the United States of 'unrecognized' or 'aboriginal' Indian title is not compensable under the Fifth Amendment"). Note that individual Indians can claim Fifth Amendment protection from takings, Hodel $v$ Irving, $107 \mathrm{~S} \mathrm{Ct} 2076$ (1987), and that the Supreme Court has constructed a trust/fiduciary doctrine to afford some protection to Indian tribal land claims. See Nell Jessup Newton, The Judicial Role in Fifth Amendment Takings of Indian Land: An Analysis of the "Sioux Nation" Rule, 61 Or L Rev 245 (1982).

103 Canby, 62 Wash L Rev 1 (cited in note 100).

106 See Sager, 95 Harv L Rev at 26-27 (cited in note 17).

107 See, for example, 25 CFR $\$ 20.1$ (n) (1988) (for purposes of certain "human services" programs, 'Indian' means any person who is a member, or a one-fourth degree or more blood quantum descendent of a member of any Indian tribe.").

${ }^{108}$ See 18 USC $\$ \S 1152,1153,3242$ (1982). See United States v Dodge, 538 F2d 770, 786-87 (8th Cir 1976) (blood quantum test). See generally Robert N. Clinton, Criminal Jurisdiction Over Indian Lands: A Journey Through a Jurisdictional Maze, 18 Ariz L Rev 503, 513-20 (1976).

${ }^{109}$ Oliphant $v$ Suquamish Indian Tribe, 435 US 191 (1978). An issue currently debated is the exercise of tribal jurisdiction over non-member Indians. See United States $v$ Wheeler, 435 US 313 (1978); and compare Duro $v$ Reina, 851 F2d 1136 (9th Cir 1987), denial of rehearing en banc, 860 F2d 1463 (9th Cir 1988), cert granted, 109 S Ct 1930 (1989) with Greywater v Joshua, 846 F2d 486 (8th Cir 1988). See generally Michael J. Proctor, Tribal Authority over Nonmember Indians, (manuscript on file with the University of Chicago Law Review).

110 See generally Grey, 37 Stan L Rev 1 (cited in note 72); Paul Brest, The Misconceived Quest for the Original Understanding, 60 BU L Rev 204 (1980).

11 See Santa Clara Pueblo, 436 US at 56. See also Ball, 1987 Am Bar Found Res J at 46-55 (cited in note 21). But see Wilkinson, 21 Creighton $L$ Rev at 775 (cited in note 82) (the Indian commerce clause gives Congress "very broad authority to legislate over the tribes"). 
decisions. Charles Wilkinson provides an apt description: the relationship between the Indian tribes and the federal government is "both pre-constitutional and extra-constitutional."112 As a consequence, federal Indian law throws into doubt some of the standard assumptions made by the legal academy in federal courts' jurisprudence. Instead of the expected (if complex) references to consent and to a federal government of limited powers, other, often unspoken rationales - conquest, violence, force - are the primary sources of the power exercised by the federal government over Indian tribes. ${ }^{113}$

One can readily see how, when Felix Frankfurter and Wilber Katz were fashioning a course in 1931 about the federal courts, they might have perceived Indian tribal issues as different, as a topic for "specialists."114 Further, while Frankfurter, Katz, and Shulman disdained "practice," the courses they constructed may well have been aimed at helping students prepare for practice. The traditional practice for graduates of elite law schools was not one in which Indian tribes were clients.

But more underlies the exclusion of Indian tribe cases than a sense that they require command of a complex body of statutes, executive action, and doctrine that law students may be unlikely to use in practice. Indian tribe cases are excluded because they are painful. The history of United States' dealings with the peoples who inhabited the continent before Western Europeans arrived is one of conquest, exploitation, and eradication. "16 Phrases like "allotment," "discovery," and "relocation," capture events that are deeply embarrassing to those committed to a vision of a United States founded upon consent and dedicated to non-discriminatory treatment. ${ }^{116}$ Unlike the disturbing history of slavery, no arguably comfortable mileposts are available. No Brown $v$ Board of Educa-

112 Wilkinson, Indian History at 116 (cited in note 21).

${ }^{113}$ Robert A. Williams, Jr., The Medieval and Renaissance Origins of the Status of the American Indian in Western Legal Thought, $57 \mathrm{~S}$ Cal L Rev 1 (1983); Robert A. Williams, Jr., Jefferson, The Norman Yoke, and American Indian Lands, 29 Ariz L Rev 165, 167-70 (1987).

${ }^{114}$ Frankfurter and Katz, Introduction, at viii $\mathrm{n} 1$ (cited in note 16).

115 See generally, Ball, 1987 Am Bar Found Res J 1 (cited in note 21); Barsh and Henderson, The Road (cited in note 22); Williams, 1986 Wisc L Rev at 219 (cited in note 89).

${ }^{116}$ See, for example, City of Richmond v J.A. Croson Co., $109 \mathrm{~S} \mathrm{Ct} 706$ (1989) (racebased distinctions very difficult to justify). The Supreme Court has sanctioned Indian preference programs, in part on the theory that such preferences are not "racial" but "designed to further the cause of Indian self-government." Morton v Mancari, 417 US 535, 554 (1974). For discussion of the "blatant doubletalk" in federal court dealings with Indian tribes, see Aviam Soifer, Listening and the Voiceless, 4 Miss Coll L Rev 319, 323 (1984) (The Law and Southern Literature Symposium). 
tion exists for Indian tribes.

The difficulty of engaging with cases about Indian tribes is exacerbated in the context of federal courts' jurisprudence. Federal Indian law challenges the central premises of "federal courts' ideology." If Richard Fallon is correct that two models, one Nationalist and one Federalist, capture the landscape of much of the debate about the role of the federal courts, ${ }^{117}$ what place is there in either model for conquest and violence? While Nationalists and Federalists might disagree about the allocation of power between state and federal government, the shared major premise - for Nationalist and Federalist alike - is of constitutionally justified and limited power. Bringing federal Indian law into the federal courts conversation unsettles some familiar assumptions about restraint upon the United States' legal authority. No act of interpretation and no elaboration of consent theory can explain federal exercise of power and dominion over Indian tribes. ${ }^{118}$ Materials about relations between the United States and Indian tribes undermine the central tenets of federal courts' jurisprudence - that the Constitution is the beginning of the analysis for the exercise of all the powers of the federal government, and that, by constitutional interpretation, the federal powers are limited and constrained.

One might then conclude that such differences result in an appropriate exclusion of federal Indian tribe law from consideration of the relations between state and federal governments. Before reaching such a conclusion, however, one should be reminded about aspects of federal/state relations that are not often stressed. In addition to Marbury $v$ Madison, another centerpiece of federal courts law is the case of Ex parte McCardle ${ }^{119} \mathrm{McC}$ Cardle involved congressional withdrawal, in 1868, of the United States Supreme Court's appellate jurisdiction over a pending habeas corpus claim. William H. McCardle was an editor of a newspaper, the Vicksburg Times. He wrote and published an editorial that stated that the Northern generals, then governing, were "each and all infamous, cowardly, and abandoned villains who, instead of wearing shoulder straps and ruling millions of people, should have their heads shaved, their ears cropped, their foreheads branded, and their per-

${ }^{117}$ Fallon, 74 Va L Rev at 1143-45 (cited in note 34).

11 See Barsh and Henderson, The Road at 53-54, 83, 88-91 (cited in note 22) (tracing the evolution of the relationship from one of treaty making to one in which Indian tribes are described as "domestic dependent nations" and as "wards" and the power to govern them explained as based upon federal "ownership of the country" (citing Cherokee Nation $v$ Georgia, 30 US (5 Pet) 1, 16-18 (1831) and Kagama, 118 US 375, 379-80 (1886)).

11974 US (7 Wall) 506 (1868). 
sons lodged in a penitentiary." 120 For this and other statements urging whites to boycott the state constitutional convention, he was imprisoned by the military government. McCardle sought habeas relief; the Supreme Court put his case over to the next Term, by which time Congress had rescinded the Court's appellate jurisdiction. The Court then upheld that rescission. ${ }^{121}$ The McCardle opinion appears in many books about the federal courts, but often with scant elaboration of the nature of the offense that formed the basis for the detention ${ }^{122}$ or of the conflicts over Reconstruction between the Southern states and the Northern government and among the branches of the federal government. ${ }^{123}$

Nor is there much discussion of the degree to which conquest, and not consent, formed the basis for the inclusion of the Fourteenth Amendment in the United States Constitution. As Bruce Ackerman explains, that amendment was not enacted "constitutionally," in the sense that the requirements of Article V of the Constitution were not met. ${ }^{124}$ Although the amendment was proposed by two-thirds of both the House and the Senate, as required by the Constitution, ${ }^{125}$ representatives from the Southern states were excluded from that Congress. ${ }^{126}$ Questions can also be raised about the ratification - either that the time to ratify ended before the requisite number of states had approved the amendment ${ }^{127}$ or

120 William W. Van Alstyne, A Critical Guide to Ex parte McCardle, 15 Ariz L Rev 229, 236 n 42 (1973), quoting Vicksburg Times (Nov 6, 1867).

121 Ex parte McCardle, 74 US (7 Wall) at 514.

122 See, for example, Hart and Wechsler at 364-66 (3d ed, cited in note 60); for a bit more detail, see Low and Jeffries at 169 (cited in note 64); Fink and Tushnet at 259 (cited in note 65 ).

${ }^{123}$ Bruce Ackerman, The Great Transformation: Ratifying the Fourteenth Amendment, ch 10, Discovering the Constitution 107-36; 146-60 (manuscript on file with the University of Chicago Law Review) (in "bringing McCardle's predicament before the Supreme Court," his lawyers "had no intention of arguing their case narrowly. . . . [P] letitioners launched a broad-based attack on the very foundations of Congress' authority to displace the Johnsonian governments with new constituencies defined by federal law." Id at 108-09 (footnote omitted)).

${ }^{124}$ Bruce A. Ackerman, The Storrs Lectures: Discovering the Constitution, 93 Yale L J 1013, 1063-69 (1984); Bruce A. Ackerman, Conventionalizing Congress: The Fourteenth Amendment, ch 8 Discovering the Constitution (cited in note 123).

125 US Const, Art V.

${ }^{128}$ Cong Globe, 39th Cong, 1st Sess 1147 (1866) (Senate), 943-50 (House). See Walter J. Suthon, Jr., The Dubious Origin of the Fourteenth Amendment, 28 Tulane L Rev 22, 29 (1953); Ferdinand F. Fernandez, The Constitutionality of the Fourteenth Amendment, $39 \mathrm{~S}$ Cal L Rev 378, 392-407 (1966); Joseph L. Call, The Fourteenth Amendment and its Skeptical Background, 13 Baylor L Rev 1, 10-12 (1961).

${ }_{127}$ Pinckney G. McElwee, The 14th Amendment to the Constitution of the United States and the Threat that it Poses to our Democratic Government, 11 SC L Q 484, 489-90 (1959). 
that a majority of eligible voters in all of the Southern states did not ratify their state constitutions, thus making problematic the capacity of those governments to ratify the amendments. ${ }^{128}$ Thaddeus Stevens, a member of Congress, explained congressional control over the South as based upon a "law of nations" that recognized the "conqueror's right" to dictate to the South. ${ }^{129}$ Yet, little is said about the conquest of the South in federal courts' jurisprudence and in the many discussions that assume the existence of "state sovereignty," that all states have the same history of consent to federal governance, and that the national government has circumscribed authority. ${ }^{130}$

Just as federal courts' jurisprudence has (despite the Southern conquest) created a set of legalistic relationships between federal government and the states, many commentators on Indian tribal law advance the possibility of creating a legally constrained relationship between the federal government and Indian tribes. Nell Jessup Newton argues for application of equal protection and due process principles to Indian tribes. ${ }^{131}$ Charles Wilkinson writes about developing "the constitutional status of tribalism," based in part on treaties among "the three landed sovereigns," Indian tribes, states, and the federal government. ${ }^{132}$ Robert Williams wants to turn to international law paradigms to delineate discrete spheres for Indian tribes, thereby enabling "Indian Nations to add their own voice to the competing discourses of the international community."133 Russel Barsh and James Henderson seek a tribal federalism in which "[t]ribes must have no less political liberty

${ }^{128}$ Michael Les Benedict, A Compromise of Principle: Congressional Republicans and Reconstruction 1863-1869 315-17 (Norton, 1974); Ackerman, The Great Transformation (cited note 123).

${ }^{129}$ Cong Globe, 39th Cong, 2d Sess 1076, 1268 (1867).

${ }^{130}$ " [T] $]$ oday's lawyers blandly suppose that the Fourteenth Amendment is validated by a straight-forward application of a single rule in Article V" of the Constitution. Ackerman, Conventionalizing Congress at 100 (cited in note 124). "Indeed, many knowledgeable professors of constitutional law do not even know that the Fourteenth Amendment uniquely required two Proclamations to gain unquestioned legal validity." Ackerman, The Great Transformation at 13 (cited in note 123).

${ }^{131}$ Newton, $132 \mathrm{U} \mathrm{Pa} \mathrm{L} \mathrm{Rev} \mathrm{at} \mathrm{236-88} \mathrm{(cited} \mathrm{in} \mathrm{note} \mathrm{99).}$

132 Wilkinson, American Indians at 6 (cited in note 22) and Wilkinson, Indian History at 120 (cited in note 21). For commentary on Wilkinson, see Frederick E. Hoxie, War of the Worlds: History Versus the Law in Charles Wilkinson's American Indians, Time and the Law, 13 L \& Soc Inquiry 791 (1988) (questioning Wilkinson's legal and historical assumptions).

${ }^{133}$ Williams, 1986 Wisc L Rev at 297 (cited in note 89); Williams, Emergence of a $\mathrm{Na}$ tional Policy, at 50-51 (cited in note 99) (suggesting that United States/tribal conflicts be submitted to binding international arbitration or adjudication). 
than the states."134

What are the bases of a vision that recognizes the autonomy of "sovereigns" within another sovereignty? What is meant by that autonomy? How much of that autonomy is dependent upon a vision of "sovereignty" that, if ever true, has surely vanished? Theories of sovereignty have long rested on the primacy of territory, of a government's control of and physical power over a specific area of land. Listen to Chief Justice Marshall, in Worcester $v$ Georgia in 1832, describing the Indian tribes as "distinct political communities, having territorial boundaries, within which their authority is exclusive." ${ }^{135}$ Listen to Justice Field in 1878, proclaiming in Pennoyer $v$ Neff that "every State possesses exclusive jurisdiction and sovereignty over persons and property within its territory." "136 The Supreme Court has expressly rejected the Pennoyer view that physical power is the touchstone of a state's authority over civil litigants. ${ }^{137}$ The Supreme Court has similarly rejected Marshall's description of Indian tribes' exclusive jurisdiction within their territories. ${ }^{138}$ While territory and physical power remain relevant to jurisdiction today, ${ }^{139}$ the statements in nineteenth century cases rest upon a world without cars, without airplanes, without FAX machines.

Federal courts' jurisprudence must struggle with claims of "sovereignty." Inclusion of materials about Indian tribes does more than deconstruct some of the traditional wisdom about the limits of the federal government's power. Learning about the interaction between federal, state, and Indian governments is learning about

134 Barsh and Henderson, The Road at 286 (cited in note 22). See also id at 209-15. Many others have written about the relationship between Indian tribes and the federal government; the selections in the text are meant to illustrate a range of possible interactions. For Supreme Court discussions of these issues, see Washington v Confederated Tribes, 447 US 134 (1980) (concerning power of states to tax activities of Indians on and off a reservation). Compare Justice Rehnquist's view that "Indian immunities are dependent upon congressional intent," id at 177, with Justices Brennan's and Marshall's claim that Indian tribes possess "aboriginal independence." Id at 167 (Brennan concurring in part and dissenting in part).

135 Worcester v Georgia, 31 US (6 Pet) 515, 556 (1832).

${ }^{136} 95$ US 714, 722 (1878). See generally Wendy Collins Perdue, Sin, Scandal, and Substantive Due Process: Personal Jurisdiction and "Pennoyer" Reconsidered, 62 Wash U L Q 479 (1987).

${ }^{137}$ See Internat. Shoe Co. $v$ Washington, 326 US 310 (1945); Shaffer v Heitner, 433 US 186 (1977).

${ }^{138}$ See Oliphant v Suquahamish Tribe, 435 US 191, 212 (1978).

${ }^{139}$ See, for example, Asahi Metal Industrial Corp v Superior Court, 107 S Ct 1026 (1987). See generally Lea Brilmayer, Justifying International Acts (forthcoming Cornell, 1989). 
how some form of group identity and governance can survive in the midst of domination - and learning that the survival of such identity and governance is a product of decisions by both the smaller and the larger groups, and of their interactions. The point is not that states and Indian tribes are equivalent. Profound differences - of history, sociology, and politics - exist between a state and an Indian tribe. But there is much to learn from thinking about both the differences and the similarities. ${ }^{140}$

The claim of sovereignty arises when one group makes a claim to be or to sustain rules different from another. A central question for federal courts' jurisprudence is how much difference between state and national laws the federal government should encourage or tolerate. The relationship between the federal and state governments and the Indian tribes reminds "us" to take claims of difference seriously and to explore the meaning of claimed distinctions between "sovereigns." Perceiving "difference" between the Santa Clara Pueblo and the United States may be easier than perceiving difference between New Jersey and the United States. But the very ease of perceiving difference between Indian and non-Indian may also obscure interaction and influence. Exploration of the relationship between the Santa Clara Pueblo and the United States shows complex interweavings of two "sovereigns." Texts about federal Indian law enable insight into what deviations from its norms the federal government will tolerate and what it will attempt to preclude, and thus provide insight into what federal norms really are.

\section{Reasons to Give VoIce}

Analytically comparable problems, embarrassment, and a belated sense of obligation to speak about the history of treatment of Indian tribes are sufficient to give rise to a claim for inclusion of materials about Indian tribes in federal courts' jurisprudence. But Indian tribe cases offer more than a chance to display appropriate sensitivity to the experiences of many within this country. Indian

140 Questions about the power of religions to live with rules different than that of the federal government raise parallel issues. See Carol Weisbrod, Family, Church and State: An Essay on Constitutionalism and Religious Authority, $26 \mathrm{~J}$ Family L 741, 743 (1987-88) ("'sovereignty' can be located in groups other than the state"). See also Lyng $v$ Northwest Indian Cemetery Protective Association, 108 S Ct 1319 (1988) (conflict between Forest Service road construction program and Indian tribes' observance of religion). See generally John Griffiths, What is Legal Pluralism?, $24 \mathrm{~J}$ Legal Pluralism 1, 2 (1986) (defining legal pluralism as a "state of affairs . . . in which behavior pursuant to more than one legal order occurs"). 
cases provide vivid insight into three central themes for federal courts' jurisprudence to explore: 1) whether and when the United States will tolerate subgroups that seek to be different and distinct and to express such distinctions by self-governance; 2) whether such differences can be sustained, given the interdependencies of the subgroup and the federal government; and 3) whether distinct governance structures are to be desired and preserved or forbidden and eroded.

\section{A. The Interdependencies of Norms}

\section{Sovereignty and Membership.}

In Santa Clara Pueblo, the Court held that sovereignty interests trumped inquiry about the legality, under federal law, of rules that (at least from a feminist perspective) subordinate women. ${ }^{141}$ Justice Marshall's protection of the Santa Clara Pueblo's "ability to maintain itself as a culturally and politically distinct entity"142 has a good deal of appeal. Membership rules can readily be understood as the core of any group's identity, and, hence, as appropriately outside the realm of consideration by any other "sovereign." As the district judge in the Santa Clara Pueblo case explained: "The importance of this [membership rule] to Santa Clara or to any other Indian tribe cannot be overstressed. In deciding who is and who is not a member, the Pueblo decides what it is that makes its members unique, what distinguishes a Santa Clara Indian from everyone else in the United States."143

But the issue of membership in the Santa Clara Pueblo requires further examination. How did the concept of membership in the Pueblo develop? Justice Marshall spoke of the "often vast gulf between tribal traditions and those with which federal courts are

141 The question of perspective is ever-present. Might I, as a non-Indian, describe the rule as subordinating, while insiders do not? The record suggests that, at least when arguing to the United States Supreme Court, Pueblo defenders also described the rule as one of subordination. According to the brief submitted amici curiae by a number of Pueblos proximate to the Santa Clara Pueblo, had the Tenth Circuit opinion finding for Ms. Martinez been upheld by the Supreme Court, "a number of male-dominance rules" would have been subject to attack. Motion to File Brief Amici Curiae and Brief of Amici Curiae of the Pueblo de Cochiti, et al, No 76-682 11 (Oct Term, 1976). See also attached affidavit of James R. Martinez, Governor of the Pueblo of San Ildefonso ("The women are in charge of the house ... and other domestic chores to support the men as the men perform their obligations. The women's obligations can be performed by outsiders without really interfering with the religious functions and obligations performed by the men"). Id at 12a.

${ }^{142}$ Santa Clara Pueblo, 436 US at 72 (footnote omitted).

${ }^{143}$ Martinez v Santa Clara Pueblo, 402 F Supp 5, 15 (D NM 1975). 
more intimately familiar."144 Was this particular rule a "tribal tradition?" How comfortable should the federal judges (all men) who decided the case have been as they worked with an implied distinction between the "Santa Claran" membership rule and perhaps but never reached in Santa Clara Pueblo - a federal norm of nonsubordination?

Neither the Santa Clara Pueblo membership rule nor the Martinez lawsuit can be understood outside the context of federal Indian law. A brief summary of some of the relevant policies is required. In the General Allotment Act of 1887,145 Congress authorized the President to "allot" land to individual Indians on reservations. The act provided for allotted land to be held in trust for a specified period of time and then conveyed to individuals. Further, the act authorized the Secretary of Interior to negotiate the purchase of "excess" lands remaining after allotment. Many commentators describe allotment as intended to erode Indian identity; individual land-holding was designed to break tribal connections and encourage assimilation. ${ }^{146}$ As Justice O'Connor has explained, the legislation "seem[ed] in part animated by a desire to force Indians to abandon their nomadic ways . . . to 'speed . . . assimilation' and in part a result of pressure to free new lands for further white development."147

By 1934, Allotment Act policies had diminished Indian land holdings from 138 million acres to 48 million acres. ${ }^{148}$ In 1928 , a group called the Institute for Government Research issued a report leveling substantial criticism at the allotment program. ${ }^{149}$ That re-

14 Santa Clara Pueblo, 436 US at $72 \mathrm{n} 32$.

14524 Stat 388 (1887), also known as the Dawes Act, upheld in Lone Wolf $v$ Hitchcock, 187 US 553 (1903).

${ }_{118}$ See, for example, DeLorio and Lyttle, American Indians, American Justice at 8-12 (cited in note 95); Kenneth R. Philp, John Collier's Crusade for Indian Reform 1920-1954 ix-xi (U Ariz, 1977); Newton, 132 U Pa L Rev at 223 (cited in note 99). Eric Foner indicates that assimilationist policies existed during the Civil War. “. . . [N]early all military and civilian officials shared a common assumption: that the federal government should persuade or coerce the Plains Indians to exchange their religion, communal form of property, and 'nomadic' way of life for Christian worship and settled agriculture on federally supervised reservations. In a word, they should surrender most of their land and cease to be Indians." Eric Foner, Reconstruction, at 462 (cited in note 35).

${ }^{147}$ Hodel v Irving, 107 S Ct 2076, 2078 (1987).

148 See William C. Canby, Jr., American Indian Law in a Nutshell 21 (West, 2d ed 1988). See also Indian Self Determination and the Role of Tribal Courts, A Survey of Tribal Courts Conducted by the American Indian Lawyer Training Program at 20 (1977) ("Tribal Court Survey").

${ }^{149}$ See Philp, John Collier's Crusade at 90-91 (cited in note 146). The Institute's report is often cited as the Meriam report, because Lewis Meriam was the director of the Institute. For description of how Indian children were forced to go to schools that prohibited them 
port helped influence the growing debate about federal Indian policy, and, in 1934, Congress passed the Indian Reorganization Act (IRA). ${ }^{150}$ The IRA was at variance with the prior effort to end all tribal identification. The act stopped allotment and required the Secretary of the Interior to attempt to restore "surplus" tribal lands acquired during allotment. The IRA also proclaimed Congress to be supportive of Indian self-governance. ${ }^{151}$ To further that goal, the IRA provided for the creation of tribal constitutions and laws, but required that such enactments be submitted to the Secretary of Interior for approval. ${ }^{162}$ The Act did permit Indians to decline to organize under its provisions, and some groups, including the Navajos, have not done so. ${ }^{153}$

The Santa Clara Pueblo was among those tribes that organized under the provisions of the IRA. ${ }^{154}$ In 1935, the Secretary of the Interior approved the Santa Clara Pueblo's Constitution and Bylaws, which began with a preamble that states: "We, the people of Santa Clara Pueblo, in order to establish justice, promote the common welfare and preserve the advantages of self-government, do ordain and establish this constitution." 155 Under the 1935 constitution, membership in the Santa Clara Pueblo extended to four groups of people: 1) those "of Indian blood" whose names appeared on the 1935 census roll; 2) all "persons born of parents both of whom are members of the Santa Clara pueblo"; 3) all "children of mixed marriages between members of the Santa Clara pueblo and nonmembers, provided such children have been recog-

from speaking their own languages, see Newton, $132 \mathrm{U} \mathrm{Pa} \mathrm{L}$ Rev at 227 (cited in note 99). 15048 Stat 984, codified as amended at 25 USC $\S 461$ et seq (1982) (also known as the Wheeler-Howard Act). See also the following series of articles: Curtis Berkey, John Collier and the Indian Reorganization Act, 2 Am Indian J 2 (July 1976); Curtis Berkey, The Legislative History of the Indian Reorganization Act, 2 Am Indian J 15 (July 1976); and Curtis Berkey, Implementation of the Indian Reorganization Act, 2 Am Indian J 2 (August 1976). ${ }^{151}$ See Indian Reorganization Act, 48 Stat 984 (1934). Obviously, there are many histories about the motivation for the IRA. See generally Philp, John Colliers' Crusade at 113-86 (cited in note 146).

15225 USC $\S 476$ (1982). See also Philp, John Collier's Crusade at 159 (cited in note 146), for a general discussion of the IRA.

${ }_{163}$ Philp, John Collier's Crusade at 163 (cited in note 146) ("Eventually 181 tribes which contained a population of 129,750 approved of the IRA, while 86,365 repudiated it, including the important Navajos. ..."). Subsequently, the Bureau of Indian Affairs issued a regulation that provided for parallel treatment of tribes incorporated under the IRA and those organized without it. See generally Lawrence C. Kelly, The Navajo Indians and Federal Indian Policy (U Ariz, 1968).

154 Philp, John Collier's Crusade at 170 (cited in note 146).

155 Constitution and Bylaws of the Pueblo of Santa Clara, New Mexico, approved Dec. 20, 1935, reprinted in Supreme Court Brief of the Petitioners, Santa Clara Pueblo v Martinez, No 76-682, Appendix at 1 (Oct Term, 1976) ("Petitioners' Brief"). 
nized and adopted by the council"; and 4) all "persons naturalized as members of the pueblo."158

After setting forth its articles of governance, the Santa Clara Constitution provided for amendment, conditioned again on submission to and approval by the Secretary of the Interior. ${ }^{157}$ On November 21, 1939, the Assistant Secretary of the Interior approved an amendment that changed the statement of membership rules that had been set forth in the 1935 constitution. The 1939 rules extended membership in the Santa Clara Pueblo to only two groups: "[a]ll children born of marriages between members of the Santa Clara Pueblo" and "children born of marriages between male members of the Santa Clara Pueblo and non-members."158 The other two possible membership routes set forth in the 1935 constitution were specifically extinguished, and with those provisions went the possibility of the exercise of discretion by the members of the Pueblo. The 1939 amendment stated: "Children born of marriages between female members of the Santa Clara Pueblo and non-members shall not be members ..." and that "[p]ersons shall not be naturalized as members of the Santa Clara Pueblo under any circumstances."169

\section{New and Old Customs.}

One of the questions that preoccupied the district and appellate courts that decided Santa Clara was whether the Santa Clara Pueblo had "changed" its membership rules in 1939. The parties to the case offered evidence about how children of women married to non-Santa Clarans had been treated prior to the 1939 Ordinance, and about the inclusion of children of unmarried Santa Claran women as members of the Pueblo. ${ }^{180}$ The lower court concluded that there had not been a "hard and fast rule" about the treatment of children of mixed marriages, but case-by-case deci-

${ }^{150}$ Id, Appendix at 1-2.

157 Id at 7.

188 Id at 16-18.

169 Id at 18.

${ }^{260}$ Martinez, 402 F Supp at 16; 540 F2d at 1047. According to the Petitioners in the United States Supreme Court, "the 1939 Ordinance is simply a written embodiment of a preexisting unwritten rule of membership that has been in existence from time immemorial." Petitioners' Brief at 9 (cited in note 155). The Supreme Court Brief of the Respondents, Santa Clara Pueblo v Martinez, No 76-682 34, 42-43 (Oct Term, 1976) ("Respondents' Brief") argued that the Ordinance was a response to changing economic conditions; the "intent and purpose ... were to hold down the size of tribal membership so that there would be plenty of money and land for the members." Id at 34; $42-43$. 
sion making. ${ }^{161}$ Given that the prior custom had not been reduced to a single specified rule and that male lineage was not always a prerequisite to being a "Santa Claran," the parties offered the courts information from anthropologists and Pueblo members about the impact of gender on one's life in the Pueblo.

The briefs and court opinions attempted to describe the Santa Clara Pueblo's pre-1939 membership rule in terms of whether it was matrilineal, matrilocal, and matriarchal or patrilineal, patrilocal, and patriarchal. ${ }^{162}$ These categories address whether membership in a given culture, religion, or tribe is dependent upon the genes of either mothers or fathers, whether choice of residence is controlled by the location of the families of either women or men, and whether power is held by either women or men. ${ }^{183}$ These concepts, formulated by Western anthropologists, assume gender as an organizing category, assume the utility of description of societies by these terms, sometimes assume interrelationship among lineage, locality, and gender control, and generally assume that societies are either one or the other. ${ }^{164}$

Diverse information is available about gender relations at the Santa Clara Pueblo. Pueblo members and anthropologists (some of whom testified at the trial) offer varying descriptions of whether the Santa Clara Pueblo was matrilineal, patrilineal, or neither. ${ }^{165}$

${ }^{181} 402$ F Supp at 16. The appellate court reversed, stating that the membership ordinance was "the product of economics and pragmatics" and "historically ... cannot be said to represent the Santa Clara tradition." Martinez, 540 F2d at 1047.

${ }_{182}$ For discussion of these terms, see Carol Meyers, Discovering Eve: Ancient Israelite Women in Context 37-46 (Oxford, 1988). See also Sandra Harding, The Science Question in Feminism 128-35 (Cornell, 1987).

${ }^{183}$ Meyers, Discovering Eve at 37-39 (cited in note 162). In Santa Clara Pueblo, some of the participants did not assume the direct relationship amongst these categories. See, for example, Respondents' Brief at 35-39 (cited in note 160); Martinez, 402 F Supp at 16; Martinez, $540 \mathrm{~F} 2 \mathrm{~d}$ at 1047.

164 Some anthropologists also seem to have assumed that matrilineal patterns were a stage of development, followed by more "advanced" cultures' adoption of patrilineal rules. See, for example, Lewis H. Morgan, The Iroquois Gens, in Kinship and Social Organization, in Paul Bohannan and John Middleton, eds, Marriage, Family and Residence 166-67 (Natural History Press, 1968). For an example of the blurring of patrilineal and patriarchal, see A. R. Radcliffe-Brown, Patrilineal and Matrilineal Succession, 20 lowa L Rev 286, 293 (1935) (" $[w]$ here rights and duties derived through the father preponderate ... we have ... a patrilineal system"). For discussions that distinguish matriliny, matrilocality, and matriarchy, see David M. Schneider and Kathleen Gough, eds, Matrilineal Kinship Preface at vixiii (Cal, 1961).

${ }^{165}$ Florence Hawley Ellis (also called Florence M. Hawley) testified at trial that the Santa Clara Pueblo was patrilineal. Respondents' Brief at 36-37 (cited in note 160). See also Florence Hawley, Some Factors in the Indian Problem in New Mexico (U NM, 1948) (considering the desirability of continuation of Indian culture; noting sexual equality as general trait of variety of Indian tribes in New Mexico); Florence M. Hawley, Pueblo Social Organi- 


\section{Prior to 1939, the Pueblo unquestionably made some distinctions} based upon gender. Role differentiation between sexes was reported, but translating the meaning of the distinctions drawn is more complex. For example, one anthropologist of Pueblo culture has written: "Distinctions of sex are marked in the Pueblo culture, in dress, in occupations, and in the ceremonial life. The distinctions are a matter of division of functions between the sexes rather than of subordination of one sex to the other." ${ }^{\text {"168 }}$ In contrast, another scholar has reported that "[w]omen were considered secondclass citizens at Santa Clara Pueblo.""167

zation as a Lead to Pueblo History, 39 Am Anthro 504, 508 (1937) (noting that men customarily own houses in Tewa cultures (of which Santa Clara is a part), but not discussing specifically the Santa Clara Pueblo).

See also W.W. Hill, An Ethnography of Santa Clara Pueblo New Mexico (U NM, 1982) ("the pattern of house inheritance was prevailingly patrilineal," id at 20; "patrilineal bias was indicated in forty of forty-eight cases of house inheritance," id at 21; that personal effects were normally equally distributed among children, as were orchards and land, id at 20-21. As of 1941, with information on 100 Santa Claran marriages, twenty nine to nonSanta Clarans, twelve of those couples lived on the Pueblo, four of those twelve involved Santa Clara women married to non-Santa Clara men. Hill makes no mention of children of inter-marriage being disadvantaged.); Elsie Clews Parsons, The Social Organization of the Tewa of New Mexico, 36 Memoirs of the Am Anthro Assoc 1, 31-35 (1929) (describing the occurrence of "foreign marriages" and giving examples of Santa Clara women married to non-Santa Claran men and living on the Santa Clara Pueblo; also mentioning the need to marry outside to avoid too close kinship relations. No mention is made of the marriage choice disabling the children from full participation); Elsie Clews Parsons, The Kinship Nomenclature of the Pueblo Indians, 34 Am Anthro 377 (1932) (discussing significance of lines of both mothers and fathers); Fred Eggan, Social Organization of the Western Pueblos (Chicago, 1950) (does not deal in depth with the Santa Clara Pueblo, but describes Pueblo culture in general. Does review the "eastern Pueblos," including Santa Clara, and notes the "considerable variation in social structure" in those Pueblos. Id at 304-11. Eggan notes that different anthropologists have described Tewa villages as patrilineal or matrilineal. Id at 305); A. Ortiz, Tewa World (Chicago, 1969) (discusses Tewa as classifying human and spiritual "existence into a hierarchy of six categories, three human and three spiritual," id at 9; argues that "moieties," summer and winter people, are central factors in Tewa life; "one is not born into a moiety but is recruited into it, and the basis of this recruitment is flexible at best. . . There is no clear and unalterable rule of recruitment into the moieties, because there is no clear and unambiguous rule of descent." Id at 57-58; critical of other anthropologists' focus on marriage systems, which Ortiz believes are not central, id and at 129-132; religious ideas and practices are more central than kinship and marriage); Edward P. Dozier, The Pueblo Indians of North America (Holt, Rinehart \& Winston, 1970) (Dozier, who describes himself as a member of the Santa Clara Pueblo [according to the Martinez's lawyers, by virtue of his mother, as his father was French] discussed the Santa Clara practices as included in the Tanoan Pueblos; "The household unit is thus a bilateral descent group. . . ." "The Tewa 'clan names' . . . are inherited variously from the father or the mother," id at 165. "In summary, Tanoan Pueblos classify kin bilaterally on a principle of generation, emphasize age, and generally ignore sex distinctions," id at 164-65). See also Dozier, Factionalism at Santa Clara Pueblo, 5 Ethnology 172 (1966).

${ }_{186}$ Parson, The Kinship Nomenclature, 34 Am Anthro at 378 (cited in note 165).

${ }^{167}$ Hill, An Ethnography at 169 (cited in note 165). See also Note, Tribal Sovereignty: Santa Clara Pueblo v. Martinez: Tribal Sovereignty 146 Years Later, 8 Am Indian L Rev 
The difficulty in interpreting this information stems from the problem of disentangling the viewer from the viewed. ${ }^{168}$ Recent feminist work has raised questions both about the perspective of the anthropologists who study culture and about the patrilineal/ matrilineal categories themselves, which may reflect more about the dualistic modeling of nineteenth and twentieth century anthropologists than the societies that they study. ${ }^{168}$ In addition to perceiving the inadequacies of the dichotomization, feminist anthropologists have distinguished between the official holders of positions of authority and those who hold power, and have attempted to be careful about transplanting Western values about roles onto other societies. ${ }^{170}$ To be concrete, because the United States' culture devalues the daily activities of food-making does not mean that those who do such tasks in other cultures are similarly devalued. ${ }^{171}$ Because United States culture exhibits dichoto-

139, 149-50 (1980) (by C.L. Stetson) ("As a patrilocal society, dependent upon a strong sense of community for its survival, Santa Clara has always been antagonistic to the idea of marriage outside the tribe.") (citing other works by E. Parsons, such as E. Parsons, I Pueblo Indian Religion pt 1, 7 (1939)).

${ }_{168}$ Martha Minow, The Supreme Court: 1986 Term - Foreword: Justice Engendered, 101 Harv L Rev 10 (1987).

${ }^{169}$ See Meyers, Discovering Eve at 24-37 (cited in note 162). See also Robert N. Lynch, Women in Northern Paiute Politics, 11 Signs 352 (1986) (failure of anthropologists to consider the roles of women in Indian culture); Rayna Green, The Pocohontas Perplex: The Image of Indian Women in American Culture, 16 Mass Rev 698 (1975) (stereotypical treatment of Indian women); Marilyn Strathern, An Awkward Relationship: The Case of Feminism and Anthropology, 12 Signs 276 (1987) (incompatibility of assumptions of the two disciplines); Jane Monnig Atkinson, Anthropology, 8 Signs 236, 238 (1982) (feminist anthropology "tackling hitherto unquestioned assumptions about sex and gender"); Rayna (Reiter) Rapp, Anthropology, 4 Signs 497 (1979) (review essay, discussing questioning of universality of asymetrical gender relations) ("our public/private conflicts are not necessarily the same as those of other times and places," id at 511). Compare the "theoretical discussion" of matriliny provided by one anthropologist, who took as a "constant" that "the role of men is defined as that of having authority over women and children. . . Positions of highest authority within the matrilineal descent group will, therefore, ordinarily be vested in statuses occupied by men." Schneider, Matrilineal Kinship at 6 in Introduction (cited in note 164).

${ }^{170}$ See, for example, M. Z. Rosaldo and L. Lamphere, eds, Women, Culture, and Society (Stanford, 1974); M. Z. Rosaldo, The Use and Abuse of Anthropology: Reflections on Feminism and Cross-Cultural Understandings, 5 Signs 389 (1980); and the response by Linda J. Nicholson, Comment on Rosaldo's The Use and Abuse of Anthropology, 7 Signs 732 (1982) (urging continued investigation of domestic/public category); S. C. Rogers, $\mathrm{Fe}-$ male Forms of Power and Myth of Male Dominance: A Model of Female/Male Interaction in Peasant Society, 2 Am Ethnologist 727 (1975); Meyer, Discovering Eve at ch 2 (cited in note 162); Louise Lamphere, Anthropology, 2 Signs 612 (1977).

171 Edward Dozier reports that the central issues for the Pueblos were the coordination of communal activities, weather control, illness, warfare, maintenance of flora and fauna, and village harmony. Dozier, The Pueblo Indians at 133, 151, 164 (cited in note 165). In contrast, Hill seems to accept United States' categories and concludes that, because women were not office holders in government nor initiates in the kachina organization, they were 
mized, stable gender-based hierarchies does not, inevitably, mean that other cultures must. ${ }^{172}$ In short, the task of federal court construction of a description of Santa Clara practices regarding women risks imposing one culture's categories upon another. While the 1939 Ordinance reflects a gendered hierarchy, ${ }_{1}^{173}$ the prior practices about treatment of children of mixed marriages are less obviously male supremacist.

Although the Santa Clara Pueblo case was litigated with much discussion of these issues, I must pause to ask whether it should matter, to a federal court or the Congress, whether the Santa Clara rule was an old or a new one. The longevity of a particular membership rule or of general rulemaking about membership may not have any relevance. An alternative conception is that tribal "sovereignty" means that its membership rules are not subject to another "sovereign's" authority. If the claim is that Santa Clara Pueblo is itself "sovereign" (either because its political life predates the federal government or because the federal government recognizes the Pueblo's autonomy), then the sovereign is entitled to change its rules, to invoke rules of recent vintage as well as those that rely upon ancient practices. ${ }^{174}$ The parties did not dispute that in response to Julia Martinez's request that her children be counted as "Santa Clarans", the tribal council refused and relied upon its 1939 rule with its gender-based discrimination. The Supreme Court opinion seems to have adopted (implicitly ${ }^{175}$ ) the view that the vintage of the rule was not relevant. The Court fo-

subordinated. Hill, An Ethnography at 169 (cited in note 165). Nonetheless, he notes that "[w]hile women played subsidiary roles at Santa Clara Pueblo, outlets for their energies were fairly numerous" and discusses women's control over food making, householding, plastering, and participation in agriculture, handicrafts, trading, childcare, and the exclusive women's religious group, the "scalp society." Id at 164. See also Vicki Camerino, The Delaware Indians as Women: An Alternative Approach, 4 Am Indian L Rev 2 (1978) (assumption that the Delaware Indians' role as "women" in Iroquois Confederacy was a lesser status is erroneous).

${ }^{272}$ See, for example, the literature on cross-gender females, Evelyn Blackwood, Sexuality and Gender in Certain Native American Tribes: The Case of Cross-Gender Females, 10 Signs 27 (1984) (cross-gender females seen as valid role prior to non-Indian culture pressures); Walter L. Williams, The Spirit and the Flesh: Sexual Diversity in American Indian Culture, 77 (Beacon, 1986) (". . . American Indians see physical body parts as much less important than a person's spirit or character").

173 "Why is excluding women always an option for solving problems men create between men?" Catharine MacKinnon, Whose Culture? A Case Note on Martinez v. Santa Clara Pueblo (1983) in Feminism Unmodified at 68 (Harvard, 1987).

174 In the words of Barsh and Henderson, The Road at 118 (cited in note 22): "Self government transcends culture; it is the right to choose culture."

175 The Court makes reference to the fact that the trial had established that the rule was of "recent vintage." 436 US at 55 . 
cused upon potential federal court oversight of membership rules and other intra-tribal matters ${ }^{176}$ and concluded that Congress had not "intended" to enable that oversight via private causes of action. ${ }^{177}$

Questions about the consistency of treatment by the United States of historically based claims and about the significance of such claims emerge from this analysis. If the history of a given tribal rule is not relevant to understanding whether federal norms "intrude," how might one make sense of many other federal government practices that assume the relevance of historical practices to claims made by Indian tribes? For example, the Department of Interior distinguishes between what it calls "historic" Indian tribes and "non-historic" Indian tribes. Historic tribes are those which, according to the federal government, predated the United States and lost their "external" sovereignty, but retained "internal" sovereignty - "those powers which are lawfully vested in an Indian tribe are not, in general, delegated powers granted by express acts of Congress, but rather inherent powers of a limited sovereignty which has never been extinguished." ${ }^{178}$ The theory is that congressional acts may limit tribal sovereignty but do not define its "sources or positive content."179 In contrast, non-historic tribes have no "inherent powers" but only those powers delegated to them by Congress or permitted to them by the Secretary of Interior. ${ }^{180}$ Similarly, groups seeking recognition as a "tribe" by the federal government often rely upon historical continuity, defined as identity over time. James Clifford has described the Mashpee Indians' efforts to obtain possession of land on Cape Cod. According to Clifford, the purpose of the federal court trial was "to determine whether the group calling itself the Mashpee Tribe was in fact an Indian tribe, and the same tribe that in the mid-nineteenth century had lost its land through a series of contested legislative acts."181

${ }^{176}$ Id at 55-58, 69-70.

177 Id at 71-72.

1781 Opinions of the Solicitor of the Department of Interior Relating to Indian Affairs at 447 (Powers of Indian Tribes) (Oct 25, 1934) (emphasis in the original) (providing an answer to the general question of what powers tribes have).

178 Id. The limitations occur, according the Solicitor, when "in the judgment of Congress, these tribes" can "no longer be safely permitted to handle" certain matters. Id.

${ }^{180}$ U.S. Department of Interior, Bureau of Indian Affairs, Developing and Reviewing Tribal Constitutions and Amendments: A Handbook for BIA Personnel, ch 1, 3 (June, 1987) ("BIA Handbook").

181 James Clifford, The Predicament of Culture: Twentieth Century Ethnography, Literature and Art 277 (Harvard, 1988). See also Paul Brodeur, Restitution: The Land 
Both the Department of Interior's distinctions between "historic" and "non-historic" tribes and the federal court's effort to decide whether current "Mashpees" are the same as past "Mashpees" might be seen as foolish endeavors. Yet much of the basis for the claim of a group's right to difference comes from the existence of that difference over time. In the 1970s, the Mashpees argued that the state of Massachusetts (in a past incarnation, one hundred years before) had taken land from them and should return it to them because it used to be theirs. The Santa Clara Pueblo claimed its right of sovereignty because it existed before the United States came into being. If Congress sought to merge Rhode Island and Connecticut, some of the protest to that proposition would be founded on the fact of history: that the borders have been borders for many years.

One possible response to arguments based on historic continuity is to say that continuity over time has little normative significance, that the Pueblo's authority to decide membership rules should be grounded in a current right to be different rather than upon proof that these membership rules were longstanding. To insist upon historical continuity may be either a search by romantics for the picturesque, ${ }^{182}$ or by conservatives, unwilling to recognize that which did not predate themselves and wanting the world as they know it not to change. Yet neither the emotive power of longheld traditions nor the potential for the oppression embodied in those long-held traditions should be denied. Southern states had a history of slavery and claimed their social self was constituted by practices about which "outsiders" should not dictate.

The longevity of a tradition and the role that tradition played in a community's social ordering is of relevance to the concern that "outsiders" are "intruding." However, the existence of a tradition does not decide whether the outsiders are really "outside," whether intrusion is really "intrusive," or whether one should indeed intrude. Before sharing the Supreme Court's assumption that the Santa Clara Pueblo's decision about its 1939 membership rules was an act of sovereignty with which the federal courts should not interfere, more information is required about the evolution of those rules in the context of the relationship between the Pueblo and the

Claims of the Mashpee, Passamaquoddy, and Penobscot Indians of New England (Northeastern, 1985); Mashpee Tribe v New Seabury Corp, 592 F2d 575 (1st Cir 1979).

${ }^{182}$ See Clifford's description of the federal court inquiry into whether individual Mashpee learned Indian dancing, wore different clothes and the like. Clifford, Predicament of Culture at $280-89$ (cited in note 181). 


\section{United States government.}

\section{Codification of Membership Rules.}

The Santa Clara Pueblo membership rule is part of the written codification of Santa Clara laws that began in 1934 with the Pueblo's adoption of a constitution. Recall the words of the Santa Clara Constitution's preamble: "We, the people of Santa Clara Pueblo, ... do ordain and establish. ..."183 The phrases are familiar because the words in the Pueblo document come from the United States Constitution. Consider the process by which tribal constitutions came into being. The Indian Reorganization Act gave Indian tribes the opportunity to incorporate, to follow United States models of lawfully chartered associations. ${ }^{184}$ The Bureau of Indian Affairs (BIA) offered assistance immediately after the passage of the IRA and continues to help in constitutional drafting. In the 1930s, the Department of Interior prepared model constitutions for tribes. "The boilerplate provisions of this model were adopted with a few alterations by virtually all tribes which voted to organize under that Act. . . . Thus, although IRA was designed to restore residual powers to tribal sovereignty, the extent and exercise of those powers were determined largely by the Interior Department."185 Many of the constitutions contain identical clauses, and many built in a subsequent role for the Secretary of Interior in approving changes to the constitutions or to the ordinances adopted pursuant to these constitutions. ${ }^{186}$

183 Petitioners' Brief, Appendix at 1 (cited in note 155).

${ }^{184}$ Some Indian tribes had constitutions prior to the IRA. See William N. Fenton, Seth Newhouse's Traditional History and Constitution of the Iroquois Confederacy, Proceedings of the American Philosophical Society 93 (1949); Arthur C. Parker, The Constitution of the Five Nations, or the Iroquois Book of the Great Law, 184 New York State Museum Bulletin 12 (1916). The BIA, however, provides models based upon the United States Constitution.

${ }^{185}$ Tribal Court Survey 23-24 (cited in note 148). See also Curtis Berkey, Implementation of the Indian Reorganization Act, 2 Am Indian J at 4 (August 1976) ("In retrospect the Interior Department played a larger role than the tribes in drafting constitutions"). For discussion of the continuity in United States policies-from relocation through tribal sovereignty and constitution-drafting to termination-as all based upon "white dominance," see William H. Kelly, Indian Adjustment and the History of Indian Affairs, 10 Ariz L Rev 559 (1968).

${ }^{186}$ Barsh and Henderson, The Road at 117-22, n 26 (cited in note 22). The authors note that a requirement of subsequent Interior Department approval was included in an earlier draft of the IRA and was supported by the BIA, but that the IRA as adopted by Congress did not provide for subsequent Department oversight. Nonetheless, the Department did succeed in having such provisions made a part of some of the constitutions drafted under its supervision. See also Kerr-McGee Corp. $v$ Navajo Tribe, 471 US 195, 198 (1985) (in the 1930s, BIA had a "policy of including provisions for Secretarial approval; but that policy was not mandated by Congress;" IRA does not require that Secretary approve tribal power 
The BIA's 1987 book, entitled Developing and Reviewing Tribal Constitutions and Amendments: $A$ Handbook for BIA Personnel, ${ }^{187}$ details BIA policy for drafting constitutions. Under both the IRA and regulations promulgated by the Secretary of Interior, approval is only accorded to "appropriate" constitutions. ${ }^{188}$ The Handbook specifies that the BIA provides assistance "from the beginning of the constitutional development process." 180 The Hand-

to tax, and IRA does not control those - such as the Navajos - who did not accept its provisions). See generally Joseph R. Garry, Indian Reorganization Act and the Withdrawal Program, in William H. Kelly, ed, Indian Affairs and the Indian Reorganization Act: The Twenty Year Record 35, 36 (U Ariz, 1954).

George E. Fay has compiled the legal documents of many of the tribes. Fay's Charters, Constitutions and By-Laws of Indian Tribes of North America 1-15 (Museum of Anthropology, U N Colo, Greely, 1967-1972) ("Fay's"). While the canvassing is not completely comprehensive, the assembled 125 constitutions, 60 charters, 20 articles of association and the bylaws of 162 tribes provide insight into the documents generated. An example in Fay's of a boilerplate provision promoted in the 1930s is: "[t]he [Indian Community Council] shall have the power to promulgate ordinances, subject to review by the Secretary of Interior, covering adoption of members." 8 Fay's at 7 (Corelo Indian Community). This provision was included, using almost exactly the same language, in the following constitutions and bylaws: Iowa Tribe of Indians of Iowa Reservation, 13 Fay's at 29; Omaha Tribe, id at 58a; Washoe Tribe of Nevada and California, 12 Fay's at 23-24; Shosone-Bannock Tribes of Fort Hall, Idaho, id at 44; Nez Perce Tribe of Idaho, id at 59; Tule River Indian Tribe, 8 Fay's at 47; and Me-Wuk Indian Community, 7 Fay's at 26.

187 BIA Handbook (cited in note 180).

18825 USC § 476 (1982); 25 CFR § 81.24(a)(3) (1988). Changes are underway. In October of 1988, Representative Morris Udall proposed legislation to limit the Department of Interior, and that bill was enacted on November 1, 1988. Under Pub L No 100-581, 102 Stat 2938 , modifying 25 USC $\$ 476$, the Department is required to hold elections for constitutional ratification within a specified period of time and to approve all constitutions that do not conflict with "applicable law" - defined as federal statutes, treaties, executive orders and final federal court opinions. The statute arguably leaves a substantial amount of discretion with the Department. See also the discussion of the proposed legislation, HR 2677, 100th Cong, 2d Sess in 134 Cong Rec 9844-49 (Oct 7, 1988). Until this legislation, the Secretary had to call elections on constitutions but could subsequently withhold approval. See Coyote Valley Band of Pomo Indians v United States, 639 F Supp 165 (E D Cal 1986) and $B I A$ Handbook at chs 4, 6 (cited in note 180). If the Secretary denies approval, the tribe may use the document it has generated as a document of governance, but the document is not an IRA "constitution" and therefore could be changed without the more elaborate amendment/election process. In addition to IRA approval requirements, some federal statutes require certain tribal decisions to be approved by the BIA. See, for example, 25 USC § 81 (1982), which requires BIA approval of the contracts and fees when Indian tribes want to employ counsel.

For criticism of the length of time taken to obtain recognition under the IRA, as currently administered by BIA, see Paul M. Rodriquez, Lumbees, 1988 States News Service (Aug 12, 1988) (Senator Sanford proposed legislation to enable recognition of Lumbee Indian tribe, which complained that the BIA process would take eight to ten years). For discussion of the enactment of the IRA and criticism of the post World War II policies of the BIA to recognize tribes, see Terry Anderson, Federal Recognition: The Vicious Myth, 4 Am Indian J, No 5 at 7 (May, 1978).

${ }^{189}$ BIA Handbook at 1-6 (cited in note 180). Under current Supreme Court preemption 
book further explains the "constitutional concepts" of delegated authority from the people to their elected leaders, of written expression of that delegation, and of protecting the rights of the members. ${ }^{190}$ Although the Handbook also asserts as a constitutional concept the protection of the "rights, resources, values and culture of the tribe,"181 many of the documents generated pursuant to the Indian Reorganization Act and under BIA's guidance resemble more closely the "values and cultures" of the United States than those of the tribes.

The BIA has provided Indian tribes with more than conceptual guidance. Detailed explanations of proposed provisions, format, and content are all offered by the Handbook, and have been offered to tribes - even before the enactment of the IRA - and consistently thereafter. ${ }^{192}$ As the Assistant Secretary for Indian Affairs explained in 1988, "[i]t is not unusual for the tribe to submit to the Bureau of Indian Affairs numerous drafts of a proposed constitution for informal review over an extended period of time prior to the submission of a final proposed draft for formal review. ..."183 The BIA encourages tribes to provide an "explanation of how membership" is determined. ${ }^{194}$ Moreover, the BIA Handbook underscores the centrality of membership in the eyes of the Department of Interior. When "a major change in membership requirements which would drastically alter or increase the size of the tribe" is made, "central office" rather than branch office review is required." Finally, when any "Indian group" seeks federal recognition as an "Indian tribe," it must submit a petition to the Department of Interior including "a statement describing in full the membership criteria" of the group. ${ }^{196}$

The Santa Clara membership rules that were initially specified

doctrine, it may be to the advantage of Indian tribes to have federal involvement, because federal involvement may protect their laws from state regulation. But see Canby, 62 Wash U L Rev at 16-19 (cited in note 100). Canby argues that the Court's decision in Rice $v$ Rehner, 463 US 713 (1983), limits the protection afforded by the preemption doctrine.

180 BIA Handbook at 2-1, 2-2 (cited in note 180).

291 Id at 2-2. The BIA also seeks to "encourage tribes to include in their constitutions provisions that promote the development of a private sector economy." Id at ch 2-11.

${ }^{192}$ See Tribal Court Survey at 23 (cited in note 148). John Collier brought drafts of constitutions to tribes in the 1920s. Deloria and Lytle, American Indians, American Justice at 140-160 (cited in note 95).

${ }_{103}$ BIA Handbook at Appendix E, E-1 (emphasis in the original) (cited in note 180).

194 Id at Appendix E, E-3.

${ }^{195}$ Id at 6 . Of the constitutions drafted in the 1930 s under BIA supervision, the vast majority required Department of Interior approval prior to the alteration of membership rules. See generally Fay's (cited in note 186).

${ }^{188} 25$ CFR \& 83.7(d) (1988). 
in its 1935 Constitution did not draw distinctions on the basis of gender and left discretion to the Pueblo to admit members. ${ }^{197}$ The 1939 Ordinance did discriminate on the basis of gender and extinguished the possibility of Pueblo members deciding, on an ad-hoc basis, to admit specific individuals. That ordinance was "approved" by the Secretary of Interior. What caused the change in rules? And what import should be assigned to that "approval"? Was the submission only pro forma and the approval a ministerial act?

In 1935, the Department made a "declaration" of its views on "Membership in Indian Tribes"; a circular addressed to all "engaged in Indian Reorganization Act" stated that "Congress [has] a definite policy to limit the application of Indian benefits . . . ."188 To implement that policy, the Department planned "to urge and insist that any constitutional provision conferring automatic tribal membership upon children hereafter born, should limit such membership to persons who reasonably can be expected to participate in tribal relations and affairs."199 Suggested tests for such membership included having both parents be recognized tribal members or be residents of the reservation or that an individual possess a "certain degree of Indian blood." "200 When those without blood or marriage ties sought adoption, "provision for the adoption of nonmembers should require approval by the Secretary of the Interior." 201 That policy statement is dated November 18, 1935; Santa Clara Pueblo's original constitution, with its inclusive membership rules, was approved just a month later. ${ }^{202}$ Four years later, the more restrictive rules were put into place. ${ }^{203}$ Forty years later, the district court concluded that the Pueblo had adopted the 1939 re-

197 In the 1940 s, Felix Cohen commented that "[n]early all tribal constitutions provide for adoption through special action by the tribe, subject to review by the Secretary of Interior". Cohen also believed that the "trend" was to recognize membership as a "political relation rather than a racial attribute." Felix S. Cohen, Handbook of Federal Indian Law 136 (GPO, 1942; reprinted U New Mexico Press, 1971).

${ }^{198}$ United States Department of the Interior, Circular No 3123 (Office of Indian Affairs, Nov. 18 1935) ("Circular No 3123") (on file with the University of Chicago Law Review) (cited in 1 Opinions of the Solicitor General [of the Department of Interior] at 813 (April 12, 1938)).

109 Circular No 3123 at 1.

200 Id.

${ }^{201}$ Id. The Department stated that its declaration was made for the benefit "of the Indians themselves . . . [who] shall appreciate its importance as it applies to their own welfare through preventing the admission to tribal membership of a large number of applicants of small degree of Indian blood." Id at 2.

${ }^{202}$ Petitioner's Brief, Appendix at 1 (cited in note 155).

203 Id at 18. 
strictive rules "in response to a sudden increase in mixed marriages, which had resulted in a proportionate strain on the economic resources of the Pueblo."204 When arguing to the Supreme Court in 1977, the Pueblo explained that the 1939 Ordinance reflects "the view that a woman member of the Pueblo is more likely to leave it than a male member and the children are more likely to be raised as cultural outsiders." 205

Department of Interior rules and the Santa Clara rule were congruent, but I do not know what if any role beyond "approval" the Department had in framing the specifics of the Santa Clara Ordinance. In other cases, the Department has upon occasion withheld or rescinded its approval of Indian tribes' decisions. For example, in the early 1980s, the Secretary of Interior "rescinded a tribal ordinance of the Moapa Band of Paiute Indians that would have permitted houses of prostitution on the Moapa Reservation in Clark County, Nevada." ${ }^{206}$ Nevada is a state in which, under certain circumstances, houses of prostitution are permitted. ${ }^{207} \mathrm{Al}$ though regional offices of the Department of the Interior initially approved the Moapa Constitution that included provisions for prostitution, the Secretary of the Interior retracted that approval on the grounds that such practices would engender political hostility to Indians and that the underlying activity, prostitution, was "frowned upon by federal policy." self-determination, the federal courts upheld the Secretary's decision as neither arbitrary nor capricious. ${ }^{209}$ Similarly, federal courts have upheld rulings by the Secretary of the Interior that overturned Indian tribes' decisions about the leasing of mineral rights

204402 F Supp at 15.

${ }^{205}$ Supreme Court Reply Brief of the Petitioners, Santa Clara v Martinez, No 76-682 13 (Oct Term, 1976).

${ }^{208}$ Moapa Band of Paiute Indians $v$ United States Department of Interior, 747 F2d 563,564 (9th Cir 1984).

${ }^{207}$ Nev Rev Stat § 244.345(8) (1987).

${ }^{208}$ Moapa Indians, 747 F2d at 564.

${ }^{209}$ Id at 566-67. The decision turns, in part, on the Moapa Constitution, which provides that the Department of Interior must approve all licensing ordinances, and that disapproval was permitted for "any cause." Moapa Const, Art V, $\$ 4$ (quoted at 747 F2d at 564). The appellate court applied federal analogues and decided that judicial review was not precluded and that "arbitrary and capricious" was the correct standard to apply. Id at 565. When deciding if the Moapa provision was a violation of federal policy, the court looked to federal statutes - such as the Mann Act, which prohibits interstate transportation of women for prostitution and the immigration act provisions permitting deportation of those connected with prostitution. Id at 566. Compare 1 Opinions of the Solicitor General [of the Department of the Interior] at 813 (April 15, 1938), admonishing the Secretary not to rescind approval of a tribal ordinance. 


\section{and other tribal activities. ${ }^{210}$}

One distinction between these examples (in which tribal decision making authority has been limited) and the 1939 Santa Clara Ordinance is that federal "interference" often occurs when the decision of a tribe has a substantial effect on non-Indians, while tribal "self-governance" is often permitted when the primary impact will be felt by members of the tribe or of other tribes. The examples of "interference" demonstrate that the Department of Interior has chosen to exercise power when it perceives that Indian tribal decisions jeopardize "federal policy." Apparently, in 1939 and subsequently, decisions to treat women and men and their children differently for purposes of membership did not implicate "federal policy."211

Federal guidance about tribal membership is not exercised only by the Executive. In 1973, Congress "restored" the tribal status of the Menominee, who had been "terminated" in the 1950s. ${ }^{212}$ In its restoration legislation, Congress also specified membership criteria for the tribe, granting membership status to "any descendants of an enrollee [of the tribe as of June 17, 1954] . . . provided such descendant possesses at least one-quarter degree Menominee Indian blood."213 Federal courts have also controlled membership. In the nineteenth century, the Supreme Court upheld legislation that empowered federal territorial courts to have final authority over citizenship claims to the Cherokee, Choctaw, Creek and Chickasaw Nations. ${ }^{214}$ In short, however much the courts that con-

${ }^{210}$ The IRA is not the only source of Interior Department control. See Yavapai-Prescott Indian Tribe $v$ Watt, 707 F2d 1072 (9th Cir 1983) (Indian tribe lacked authority to terminate unilaterally commercial lease executed in accordance with federal law that required Secretary of Interior approval for leasing). See also Pawnee $v$ United States, 830 F2d 187 (Fed Cir 1987) (upheld Secretary of Interior's approval power under statutes; Interior did not have obligation to obtain highest price for gas sold). Compare Quantum Exploration Inc. $v$ Clark, $780 \mathrm{~F} 2 \mathrm{~d} 1457$ (9th Cir 1985) (tribe can rescind proposed mineral agreement prior to Interior Department approval or disapproval).

${ }^{211}$ Compare Reynolds v United States, 98 US 145 (1878); Cleveland v United States, 329 US 14 (1946) (religious belief in polygamy does not insulate that practice from federal criminal prosecution), discussed in Weisbrod, $26 \mathrm{~J}$ Family L 741 (cited in note 140). Under the recent amendments to the IRA (see note 188), the Department of Interior will have to rely upon statutes, treaties, final court decisions, and executive orders to determine if tribal constitutions conflict with federal "law."

${ }^{212}$ Menominee Restoration Act, 25 USC $\S \S 903-903(f)$ (1982) (repealing the Act of June $17,1954,25$ USC $\$ \S 891-902$ (1954), that terminated the tribe). See generally Note, Terminating the Indian Termination Policy, 35 Stan L Rev 1181 (1983) (by Michael C. Welch).

${ }^{213} 25$ USC $\$ 903 \mathrm{~b}(\mathrm{c})$. For the regulations on how to establish "an American Indian group" as a "tribe," see 25 CFR § 83 et seq (1988). See generally Stephen J. Herzberg, The Menominee Indians: Termination to Restoration, 6 Am Indian L Rev 143 (1978).

${ }^{214}$ Stephens $v$ Cherokee Nation, 174 US 445 (1899). The Court also found constitu- 
sidered the Santa Clara Pueblo case wanted to assume membership rules were purely a function of that group's decisions, the history of membership rules for Indian tribes shows the pervasive influence of United States law on the creation and codification of such rules.

To acknowledge the United States' role in these rules is not to deny the role of the Pueblo. Cultural interaction was, of course, at work - and interaction "works" in two directions. Indian tribes, such as the Iroquois Confederacy (which included the Mohawk, Seneca, Onadaga, Oneida, and Cayuga tribes) had a structure of government that predated and may have influenced the drafting of the United States Constitution. ${ }^{215}$ Some Indian tribes, such as the Cherokee in the nineteenth century, had detailed written laws that were in some respects similar to those of the United States. ${ }^{216}$ The enactment of the Indian Reorganization Act affected the laws of the Santa Clara Pueblo. Before 1935, it did not distinguish religious and political governance. ${ }^{217}$ Then, when writing its constitution for purposes of organizing under the IRA, the Pueblo adopted a formal codification of membership rules and the election of political leaders, distinct from religious leaders, who hold specified, delegated powers. ${ }^{218}$ But in writing its constitution, the Pueblo was

tional a congressionally created commission with the authority to hear claims to citizenship in certain Indian tribes. Id at 486. Stephens is a case of interest for those intrigued by the constitutionality of "Article I" courts because the Article I court's "final" authority was upheld. Compare Richard H. Fallon, Jr., Of Legislative Courts, Administrative Courts, and Article III, 101 Harv L Rev 915 (1988) (need for Article III courts to review at least some aspects of decisions of Article I judges).

${ }^{215}$ See Parker, Constitution of the Five Nations (cited in note 184); Bruce E. Johnson, Forgotten Founders (Gambit, 1982). See also Kirke Kickingbird, "In Our Image. . . , After Our Likeness": The Drive for the Assimilation of Indian Court Systems, 13 Am Crim L Rev 675 (1976).

${ }^{216}$ See Laws of the Cherokee Nation, Passed During the Years 1839-1867 (1868); see also Acts and Resolutions of the Creek National Council of the Extra Session of April, 1894 and the Regular Session of October, 1894 (Scholarly Resources, 1973 reprint). See generally Arrell M. Gibson, Constitutional Experiences of the Five Civilized Tribes, 2 Am Indian L Rev 17 (Number 2, 1974).

${ }^{217}$ Dozier, Pueblo Indians, 68-78, 104-06, and especially 187-89 (cited in note 165).

${ }^{218}$ See Hill, Ethnography at ch 9 (cited in note 165) (on political governance of the Santa Clara). See also Frank Pommersheim, The Contextual Legitimacy of Adjudication in Tribal Courts and the Role of the Tribal Bar as an Interpretive Community: An Essay, 18 NM L Rev 49, 55 (1988) ("most tribal constitutions were drafted by the Bureau of Indian Affairs without tribal input and consequently reflected little, if any, direct local concern"). Tribal Court Survey at 27, 45 (cited in note 148) (notes Department of Interior's "pervasive influence" over development of tribal governance-by the time of survey, 84 percent of tribes had written constitutions). Recently, some tribes have been amending their constitutions to limit Bureau of Indian Affairs powers over approving changes. Pommersheim, 18 NM L Rev at 55. 
also responsive to its own needs. One historian describes how the Santa Clara Pueblo used the IRA process as a way to "solve internal problems" and, by its constitution, "protected traditionalist values by requiring that each [member of the tribal] council speak the Tewa language fluently."219

\section{The Need for Membership.}

The Santa Clara Pueblo has a long history. Anthropologists and ethnographers trace its roots to the fifteenth century. ${ }^{220} \mathrm{~A}$ substantial amount of information is available about the Pueblo's history, including its religious, social, and political organization. During the period prior to the codification of membership rules in the 1930 s, scholars of the Santa Clara Pueblo did not discuss "membership" as an organizing feature of the society. Further, if the Martinez family is illustrative, "membership" as defined in the 1939 Ordinance may still not be a central factor in some important aspects of the community's life. The lower courts stated that the children of the Martinez family spoke Tewa, the language of the Pueblo, and participated in its religious and cultural life. ${ }^{21}$

"Membership" itself is a category created by the Santa Clara Pueblo in the context of its interaction with the United States. ${ }^{222}$ Membership is a category imposed by the United States, which has "counted" Indians for a variety of purposes since the cavalry went around naming and numbering Indians in the nineteenth century. Indian "membership" is relevant to a myriad of federal jurisdictional rules. ${ }^{223}$ United States rules also provide the basis for the generation of restrictive "membership" practices, for the United States offers a limited pool of resources to those who are "members" of Indian tribes. ${ }^{24}$ The laws of the United States use lineage

210 Philp, John Collier's Crusade at 170 (cited in note 146).

${ }^{220}$ Dozier, Pueblo Indians at 38-39 (cited in note 165). Determinations of the longevity of the Pueblo turn on perceptions of the continuity of a delineated political community. See Clifford, Predicament of Culture (cited in note 181).

221 Martinez, 402 F Supp at 14; Martinez, 540 F2d at 1047.

222 The point can be extended from membership rules to the conception of Indian tribes. "The term 'tribe', a word whose origin is European and which by definition could not have had meaning for Americans before 1492, emerges from human encounters - from history. ..." Hoxie, 13 Law and Soc Inquiry at 797 (cited in note 132). In some instances, the United States expressly created "tribes." See Shoshone Tribe v United States, 299 US 476 (1937).

${ }^{223}$ See Clinton, 18 Ariz L Rev at 513-20 (cited in note 108).

224 See, for example, 25 USC \$ 450b(a) (1982) (designating beneficiaries of Indian Self Determination and Education Assistance Act as including any "member of an Indian tribe"). The Interior Department also attempted to be involved with individual membership 
as one of the indications of whether an individual is an Indian. ${ }^{225}$

Moreover, assimilationist policies of the United States attempted to weaken individuals' tribal identification based upon shared work, shared culture, and shared language, thereby encouraging tribal identification based upon lineage ties. It has been the policy of the United States to encourage Indian children to live away from their homes, to go to boarding schools and to meet individuals other than those from their tribe. ${ }^{226}$ As anthropologists of the Santa Clara Pueblo have noted, in the twentieth century intermarriages between Santa Clarans and non-Santa Clarans began to increase, as mobility and larger cultural pressures affected the previously agrarian and self-contained society. ${ }^{227}$

5. The Benefits of Membership.

Federal involvement is not limited to the process by which "membership" rules are defined and codified, nor to creating the cultural backdrop that made "membership" an issue. Federal benefits (some might call them "reparations"228) flow directly to those who are counted as "members." While the federal government can define Indian status differently than a tribe might, ${ }^{229}$ the federal government also relies upon tribal definitions as a basis for the distribution of benefits. ${ }^{230}$

The availability of federal benefits is central to understanding why the Martinez family tried to obtain recognition of its children

decisions and urged tribes to pass restrictive membership rules. See notes 198 to 201 and accompanying text.

${ }^{225}$ See 25 USC §§ 181-184, ("Indian" mothers may pass on rights to tribal property) (see notes 246-49 and accompanying text); Menominee Restoration Act, 25 USC $\S 903(\mathrm{~b})$ (one quarter blood requirement). See also Article II of the Treaty with the Sioux Nation of Indians of September 29, 1837 in Senate Executive Documents, 53rd Cong, 2d Sess, In Re Sioux Mixed Blood Indians, Ex No 58 at 28 (payments to those "having not less than one quarter of Sioux blood"). Compare Cohen, Handbook at 136 (cited in note 197) (urging "political" rather than "racial" basis for membership).

226 The BIA had a variety of assimilationist policies in the 1920 s, including trying to ban Indian school children from speaking languages other than English. See Newton, $132 \mathrm{U}$ $\mathrm{Pa} L \mathrm{Rev}$ at 227 (cited in note 99).

${ }^{227}$ Hill, Ethnography at 155-157 (cited in note 165); Dozier, Pueblo Indians at 9-14 (cited in note 165).

${ }^{228}$ See Boris I. Bittker, The Case for Black Reparations 71-77 (Random House, 1973) (exploring payments to tribes as model for United States' response to blacks). Much of the payment to tribes is based upon treaty provisions and trustee obligations. See Prucha, The Great Father, Vol II at 1016-23 (cited at note 22).

${ }^{228}$ Delaware Tribal Business Comm. $v$ Weeks, 430 US 73, 84-86 (1977).

${ }^{230}$ See, for example, 25 USC $\S 450 \mathrm{~b}$ (a) (beneficiaries of the Indian Self-Determination and Education Act are the "member[s] of an Indian tribe"); 25 CFR § 61 (1988) (listing the few tribes for which the Secretary of the Interior will define membership). 
as members of the Pueblo. ${ }^{231}$ According to the trial court opinion, the "most important of the material benefits [that Ms. Martinez's children sought] is that referred to as land use rights." United States government holds the Pueblo land in trust for the Pueblo as a whole. The Santa Clara Council has authority to specify individual use of land. The United States government, through the Department of Housing and Urban Development, gives monetary assistance to member Indians who build homes on Pueblo land. ${ }^{233}$ Federal policy looked to tribal decisions; the Martinez family argued that, without the Pueblo's recognition of them as members, the Martinez children could not receive federal health and housing assistance. ${ }^{234}$ Thus, being a "member" of the Santa Clara Pueblo was not simply an event of moment for purposes of that community.

Exactly how the lack of Santa Claran membership affected the Martinez family was a matter of dispute between the parties. Julia Martinez's lawyers argued in their Supreme Court brief: "Denial of membership has caused hardship to the Martinez family, especially in obtaining federal medical care available to Indians. In 1968 Julia Martinez's now-deceased daughter Natalie, suffering from strokes associated with her terminal illness, was refused emergency medical treatment by the [federally-funded and run] Indian Health Service. This was solely because her mother had previously been unable to obtain tribal recognition for her." ${ }^{235}$ The Pueblo responded that it was not at fault, that it "had no control over whether or not the Martinez children would obtain medical care. This was a matter solely within the province of the Bureau of Indian Affairs."236

The Supreme Court did not probe the effects of Santa Claran recognition of the Martinez children on federal benefits. Moreover, while the Court assumed the primacy of membership for tribal sov-

${ }^{231}$ Respondents' Brief at 2-3 (cited in note 160 ).

${ }^{232}$ Martinez, 402 F Supp at 14.

${ }^{233} 24 \mathrm{CFR} \& 905$ (1988).

234 Respondents' Brief at 2-3 (cited in note 160), and conversation with Richard Collins, one of the Martinez' family's attorneys, Nov 19, 1988.

${ }^{233}$ Respondent's Brief at 3 (cited in note 160). See generally U.S. Congress, Office of Technology Assessment, Indian Health Care 24 (GPO, April 1986) ("To be eligible for [Indian Health Service] direct services, a person need only be of Indian descent and be regarded as an Indian by the Community in which he lives .....")

${ }^{236}$ Petitioners' Reply Brief at 13 (cited in note 205). See also Petitioners' Brief at 33 (cited in note 155) ("It is extremely unfortunate that the Martinez family had difficulty enrolling their children for purposes of Federal benefits .... [T] his is in no way ... the fault of Santa Clara Pueblo"). 
ereignty, ${ }^{237}$ the Court did not discuss how often federal law has exercised control over Indian tribal membership or how federal benefits are linked to tribal membership. ${ }^{238} \mathrm{Ms}$. Martinez's request that her children be "counted" as Santa Clarans had consequences both for their interactions within the Santa Clara Pueblo and for them as "Indians" in the United States, but such consequences did not attract the Supreme Court's interest.

\section{Membership and Gender.}

The Santa Clara Pueblo choose to link membership with gender and to limit membership to those who could claim that their fathers were Santa Claran. I do not know the genesis of this rule. Some suggest that the rule reflects the gendered hierarchy of the Pueblo, that the male members of the Pueblo wanted to deter women from marrying non-Santa Claran men. ${ }^{239}$ But questions need to be asked about how the Pueblo's gendered hierarchy came into being; the United States often singled out men to be designated as leaders of Indian tribes. Santa Claran men might have held the power to make rules at least in part because the United States assumed men and only men could be rulemakers. ${ }^{240}$

${ }^{237}$ Santa Clara Pueblo, 436 US at 72 n32.

238 For example, the Indian Health Service has proposed that it only provide services to "members of a federally recognized Indian tribe," who "reside" in areas designated by the Service as a "Delivery Area," and to non-member "natural" children, under the age of 18, of those who are members of a federally recognized tribe and who reside within a "Delivery Area." See the Final Rule of the Department of Health and Human Services, Indian Health Service, 42 CFR $\S 36.12$ (a) (Oct. 1, 1988). See also 52 Fed Reg 35044, 35048-49 (Sept 16, 1987). That rule resulted in substantial controversy and its effective date was "suspended" until October 15, 1988. 53 Fed Reg 37762 (Sept 28, 1988). Congress then limited the rule; a rider was attached to an Interior Department appropriation bill. The rider provided that no funds allocated for fiscal year 1989 could be used to implement the rule. Pub L No 100-446, 100 Stat 1817 (Sept 17, 1988). Subsequently, the Indian Health Care Improvements Act, Pub L No 100-713, 102 Stat 4838 (Nov 23, 1988), directed the Secretary of Health and Human Services to conduct a study to determine the impact of the eligibility requirements on health services to Indians. See generally Indian Health Care 25-36 (cited in note 235) (analyzing options to limit eligibility for services).

${ }^{239}$ According to Alan Taradash, who was one of the attorneys who represented the Martinez family, the Santa Clara Pueblo had begun to impose a patrilineal rule in 1928. In the course of discovery for the lawsuit, Mr. Taradash reviewed the minutes of the Pueblo council during the 1920s and learned that the councilmen were concerned about keeping "their" women from marrying non-Santa Claran men and from having to share the Pueblo's resources with outsiders. Conversation with Alan Taradash (Nov 23, 1988). See also Hill, Ethnography at 20-1 (cited in note 165) (women as "second class" citizens).

${ }^{240}$ See Rayna Green, Native American Women, 6 Signs 248, 253 (1980) (discussing John Collier, "[a]rchitect of the Indian Reorganization Acts which supported tribal men and virtually disenfranchised Indian women"; "matriarchal, matrifocal, and matrilineal societies were neither acceptable nor comprehensible to members of European patriarchies." Id at 
The 1939 Santa Clara membership rules are also congruent with United States' traditions of subordination of women. United States common law rules were that the husband conferred status upon the wife $e^{241}$ and the father conferred status on the child. As one nineteenth century lawyer explained, "[t]he rule is a very old one, both by the Roman civil law and the English common law, too elementary to require authorities ... that the offspring of married parents takes the status of the father." ${ }^{242}$ In contrast, some nineteenth century writers described the interests of Indian women in tribal property to be great, and sometimes greater than, the interests of men. The writers also stated that such treatment of women was further proof of Indian tribes' lack of "civilized" ways. ${ }^{243}$

When considering the genesis of the Santa Clara membership rules, I wonder whether federal statutes, existing since the late 1880 s and linking gender, lineage, and property rights, played any role. ${ }^{244}$ In 1888 , Congress enacted a statute (still on the books) that provided that an "Indian woman" who married a citizen of the

250). See also Lone Wolf v Hitchcock, 187 US 553, 557, 564 (1903) (Congressional discussion about whether a tribal resolution was signed by "three fourths of the adult males").

For discussions of roles of Indian women, see Shirley R. Bysiewisz and Ruth E. Van de Mark, The Legal Status of the Dakota Indian Woman, 3 Am Indian L Rev 255, 266 (1975) (Dakota Indian women had more political and social power within the tribe in nineteenth century than did their non-Indian counterparts); Carolyn Thomas Foreman, Indian Women Chiefs 53 (Zenger, 1976) ("Tonawanda Senecas are governed by thirty-four chiefs who are elected by the women of the tribe"); Gretchen M. Bataille and Kathleen Mullen Sands, American Indian Women: Telling Their Lives at viii (U Neb, 1984) (criticizing popular view of women as inferior; "research about American Indian women ... have either ignored the power of women within tribal structures or undervalued or inadequately valued it"); DeLoria and Lytle, American Indians at 88-89 (cited in note 95) (Iroquois Constitution placed "ownership of the seats on the council [the central decision making body] . . . in the clan mothers so that women had a powerful voice in selecting who sat as representatives of the people").

${ }^{241}$ Barber $v$ Barber, 62 US 582, 600-601 (1858) (Justice Daniel's dissent addressed the issue of a wife's civil status and applied the English common law rules, "by which the husband and wife are regarded as one person, and her legal existence and authority in a degree lost and suspended during the existence of the matrimonial union.")

${ }^{242}$ H. E. Dewey, attorney for a claimant in a land dispute. See Senate Exec Doc, In Re Sioux Mixed Blood at 35 (cited in note 225).

${ }^{243}$ Letter of Hoke Smith, Secretary, Commission on Indian Affairs, stating that the common law rule was that children follow father, but perhaps the "civil law rule relating to slaves prevails among the Indians, and the children follow the condition of the mother." Senate Exec Doc, In Re Sioux Mixed Blood at 104 (cited at note 225). Smith also argued that, to allow allotment of land to a particular woman would undermine "civilizing of Indians." Id at 107. See also Robert Cristy, detailing the "Indian Women, their tribal status and rights of property," id at 41-42. For a discussion of Hopi women's control over property, see Ernest Beaglehole, Ownership and Inheritance in an American Indian Tribe, 20 Iowa L Rev 304, 305-08 (1935).

${ }^{244}$ See 25 USC §§ 181-184 (1982). 
United States gained United States citizenship but retained her interest in tribal property. ${ }^{245}$ In 1897, Congress legislated that the children of an "Indian woman" and a "white man" married prior to the enactment of that legislation would have the same rights and privileges as did other members of the mother's tribe. ${ }^{246}$ This legislation altered the United States' common law rule that the "condition of the father prevails in determining the status of the offspring." "247 Some federal officials explained the 1888 legislation as aimed at encouraging assimilation of Indians. ${ }^{248}$ The thesis was that women would follow men and that male heads of households would provide the cultural framework for the household. It was hoped and assumed that if "white men" could not by virtue of marriage assert title over tribal property, white men would not live with the Indian women to whom they were married on the reservation. When the women followed the men, they would then live and raise their children in a white culture. ${ }^{249}$ Federal administrative

246 An Act in Relation to Marriage Between White Men and Indian Women, ch 818, 25 Stat 392 (codified at 25 USC $\$ 182$ (1982)). Women members of the "five civilized tribes in Indian territory" were exempt because (according to Congress), the federal government had granted those tribes "entire autonomy." Statement of Senator Dawes, 50th Cong, 1st Sess (Jan. 17, 1988), 19 Cong Rec 512. For the statute to apply, women must be recognized by the tribe as a member. See 1 Opinions of the Solicitor of the Department of the Interior Relating to Indian Affairs 113 ("Intermarriage, enrollment of children born," June 16, 1924).

${ }^{246} 25$ USC $\S 184$ (1982). The legislative history of this section is sparse. Members of the Senate expressed concern about the disabilities of children of Indian women, who, under the 1888 legislation, may not have been able to inherit their mother's interest in tribal properties. See 30 Cong Rec S 728 (April 15, 1897).

${ }_{247}$ See letter of George H. Shields, Assistant Attorney General (Nov 27, 1891), in Senate Exec Doc, In Re Sioux Mixed Blood at 6 (cited in note 225).

248 Cohen, Handbook at 186-87 (cited in note 197) (noting that the 1897 legislation does not bestow rights to tribal property on children born of marriages "contracted after passage of the act"); United States $v$ West, 30 F2d 989, 990 (DC Cir 1929); Pape v United States, 19 F2d 219, 220 (9th Cir 1927); Oakes v United States, 172 F 305, 308 (8th Cir 1909) (policy of "inducing the Indians to abandon their tribal relations and adopt the customs of civilized life"). This law did not apply to all tribes. See note 245. See also Cherokee Intermarriage Cases, 203 US 76 (1906) (upholding Cherokee law that provided that those who intermarried into the Nation after the enactment of the legislation did not gain property rights). Prior to the 1888 legislation, the Act of March 3, 1875, ch 131, § 15, 18 Stat 420, published at 43 USC $\S 189$ (1982) and repealed effective Oct 21, 1976, by Pub L 94-579, $§ 702,90$ Stat 2787 , stated that Indians who were twenty-one or the "head of a family and "abandon[ed]" tribal "relations" kept rights to Indian property.

${ }^{249}$ Another possibility is that this legislation was aimed at encouraging the provision of sexual partners for "white men." The legislation did try to limit "white men's" control over tribal assets. See 25 USC $\S 181$ (1982). In 1885, the Secretary of the Interior reported that " 'squaw men,' who marry or act as husbands of Indian women [have an] evil influence...., they foment discord . . . and incite opposition on the part of the Indians to the measures adopted ... by the Department . . . for [Indian] advancement and civilization." Report of the Secretary of the Interior, HR Exec Doc 1, pt 5, 49th Cong, 1st Sess, in 11 House Execu- 
regulations have also distinguished between "Indian men" and "Indian women"; for example, the BIA provided families of Indian men, married to non-Indian women, with general assistance more readily than when Indian women married non-Indian men. ${ }^{250}$

The 1939 codification of female subordination seems to have been supported, if not influenced and encouraged, by the traditions of the United States, a country in which women have long been expected to "follow their men," a country in which home, name, income and status are for many women defined by the home, name, income and status of the men to whom they are related as wives and daughters.

\section{Joint Venturing.}

As a non-Indian, I am conscious of what Mari Matsuda has called the dangers of "intrusion and preemption."251 But I cannot share the ease with which the Supreme Court in Santa Clara Pueblo assumed the 1939 Ordinance to be an artifact of Santa Clara sovereignty. ${ }^{252}$ The emergence of a codified, written, non-discretionary, gender-based membership rule is linked to the Pueblo's decision to organize under guidance of the Department of the Interior, is linked to the Pueblo as a recipient of federal funds, and is linked to the Pueblo as situated in a United States culture that has made patrilineal and patriarchal rules so familiar that, to some, they seem uncontroversial.

These interdependencies do not leap out from the pages of the Supreme Court opinion in Santa Clara Pueblo. Rather, the Court's construction of the legal issues submerges the traces of the federal role in the Santa Clara decision to exclude the children of some of its women members. The Court cast the statutory interpretation

tive Documents 28 (GPO, 1886). The Secretary recommended legislation that would make "any Indian woman who shall hereafter marry a citizen of the United States . . . a citizen." Id at 29. In the legislative debate, members of the House argued that the bill would discourage marriages between white men and Indian women, or, at least, would "civilize them both together." See 19 Cong Rec pt 7 at 6885-86 (July 26, 1888). See also Sheppard v Sheppard, 104 Idaho 1, 655 P2d 895, 904 (1982) (legislative history of $\S 181$ ). In 1887, as part of the General Allotment Act, Congress conferred United States citizenship on all Indians, "born within the territorial limits of the United States who have voluntarily taken up ... residence separate and apart from any tribe of Indians ... and has adopted the habits of civilized life." Act of Feb 8, 1887, ch 119, § 6, 24 Stat 388, 390. See also note 6.

${ }^{230}$ Bysiewicz and Van de Mark, 3 Am Indian L Rev at 276-77 (cited in note 240).

251 See Mari Matsuda, Affirmative Action and Legal Knowledge: Planting Seeds in Plowed-Up Ground, 11 Harv Women's L J 1, 13 (1988).

${ }^{252}$ See 436 US at $72 \mathrm{n} \mathrm{32.} \mathrm{Compare} \mathrm{Barsh} \mathrm{and} \mathrm{Henderson,} \mathrm{The} \mathrm{Road} \mathrm{at} 245$ (cited in note 22) (membership rules as "product of federal manipulation"). 
question as pitting a group's decision about how to describe its membership against the rights of one of that group's members. ${ }^{253}$ As the Court stated: "[E]fforts by the federal judiciary to apply. . . [the Indian Civil Rights Act] . . . may substantially interfere with a tribe's ability to maintain itself as a culturally and politically distinct entity."254 Under that framework, the case has considerable poignancy; decisions about membership, about inclusion and exclusion, are at the core of self description. If the federal government were serious about Indian tribes' rights of self constitution, how could a federal court or even Congress intrude? Given the current federal policy of support of tribal sovereignty, given some members of the Supreme Court's ambivalence about women's rights, ${ }^{255}$ and given some members of that Court's unease about any "new" implied federal causes of action, ${ }^{258}$ the Court's construction of the problem is understandable.

But the majority's description is too simple, too easy, and ultimately deceptive. The "Santa Clara Rule" is intertwined with United States' rules and culture. James Clifford has said it well: "Modern Indian lives - lived within and against the dominant culture and state - are not captured by categories like tribe or identity."257 Implicit in the Court's opinion, in its references to Santa Clara Pueblo as a distinct political entity, is what Clifford calls the erroneous "idea of cultural wholeness."258 The restrictive, gender-discriminatory membership rule "of" the Santa Clara Pueblo is generated out of conditions of adversity, conditions imposed by centuries of United States policy towards Indian tribes. The rule is written in the light of limited federal benefits to be divided amongst those who bear the label "Santa Claran." The rule is comprehensible to the "dominant culture" because it too accepts subordination of women.

Many commentators sympathetic to tribal sovereignty have heralded the Santa Clara Pueblo case as an important marker in

${ }^{253}$ Ronald R. Garet, Communality and Existence: The Rights of Groups, 56 S Cal L Rev 1001, 1035-36, 1046-47 (1983).

${ }^{254} 436$ US at 72 (footnote omitted).

2ss Three years later after Santa Clara Pueblo was decided, in Michael M v Superior Court, 450 US 464 (1981), which was a constitutional challenge to California's statutory rape law, the majority continued to evaluate distinctions based upon gender by an intermediate rather than "strict" scrutiny, and all members of the Court ignored the violence that had accompanied the rape. See generally Sylvia A. Law, Rethinking Sex and the Constitution, $132 \mathrm{U}$ Pa L Rev 955 (1984); MacKinnon, Feminism Unmodified (cited in note 173).

${ }^{258}$ See note 270 (court movement away from implying rights of action).

${ }^{257}$ Clifford, The Predicament of Culture at 337 (cited in note 181).

$288 \mathrm{Id}$. 
federal Indian law. From the perspective of tribes, the Indian Civil Rights Act of 1968 is an example of federal intrusion; Santa Clara Pueblo is, to some extent, a buffer. I have not explored the Santa Clara Pueblo case to offer a "better" answer on the tribal sovereignty/federal intrusion issue than that given by the Court, nor am I claiming that the role the United States played in creating tribal rules justifies further intrusion. ${ }^{259}$ Rather, my purpose is to demonstrate that the case tells more about United States' norms than it does about tribal norms. I am skeptical about how much of a safe haven Santa Clara Pueblo provides for those seeking tribal sovereignty. Because federal norms about the treatment of women were not really threatened by the Santa Clara Pueblo membership rule, the case was an "easy" one for the Court to proclaim its commitment to tribal sovereignty. For those of us who believe in women's rights and are also concerned about federal government imperialism, the case becomes hard. ${ }^{260}$

\section{B. Separate but Assimilated}

The case of Santa Clara Pueblo arose not only because of 1934 federal legislation supporting tribal sovereignty, but also because of 1968 federal legislation, the Indian Civil Rights Act, which imposed federal rights on the relationship between tribal members and tribes. A brief summary of the federal policy shifts from 1934 to 1968 is in order. As many have detailed, ${ }^{261}$ from 1934 until the early 1950s, the IRA policy of tribal self determination held sway. Then a new policy gained prominence, that of "termination."262 Under "termination," some Indian tribes lost their status as federally recognized "tribes," ${ }^{263}$ as the federal government once again

259 See Sylvia A. Law, Homosexuality and the Social Meaning of Gender, 1988 Wisc L Rev 187, 230 (1988) (how the Supreme Court used "the history of oppression of gay and lesbian people ... as its own justification" for continued and additional oppression).

260 "I find Martinez a difficult case on a lot of levels, and I don't always find cases difficult." MacKinnon, Feminism Unmodified, at 66 (cited note 173). So did some of the participants in the case before the Supreme Court. The American Civil Liberties Union debated which side to take, as did the Department of Justice. Conversations with Steven Tullberg, of the Indian Law Resource Center; and with Drew Days, Assistant Attorney General for Civil Rights, 1977-80; Professor of Law, Yale Law School (Spring, 1989).

${ }^{261}$ See, for example, Barsh and Henderson, The Road at 112-37 (cited in note 22).

${ }^{262}$ House Concurrent Resolution 108, 83rd Cong, 1st Sess (August, 1953), in 67 Stat B132, declared that termination was the long range goal of Indian policies, that Indians would eventually lose all distinct status and the tribes would be dismantled. See generally Donald L. Fixico, Termination and Relocation: Federal Indian Policy, 1945-60 198-203 (U NM, 1986); Barsh and Henderson, The Road at 125-133 (cited in note 22).

${ }^{263}$ See notes 212-13 and accompanying text. See generally Charles F. Wilkinson and Eric R. Biggs, The Evolution of the Termination Policy, 5 Am Indian L Rev 139 (1977); 
pursued the assimilationist goals that had animated the allotment period.

Starting in the middle of the 1960s, an era during which civil rights consciousness was great, members of Congress began to express concern about the rights of Indians vis-a-vis their tribes. One result was the Indian Civil Rights Act of 1968 (ICRA). ${ }^{264}$ Billed both as insuring civil rights of Indian tribe members and as protecting the sovereignty of Indian tribes, the ICRA made some, but not all, of the Bill of Rights applicable to Indian tribe members. ${ }^{260}$ As noted above, ICRA specified only one remedy, habeas corpus, which reflected the particular concern that tribal decisions about incarceration be made subject to reconsideration by a federal court. ${ }^{266}$

Before the Supreme Court heard Santa Clara Pueblo v Martinez, many lower courts had implied remedies beyond habeas corpus for breaches of rights enumerated in the ICRA. ${ }^{267}$ However, by the time Santa Clara Pueblo was before the Court, federal policies about tribal sovereignty and about federal rights had shifted

Felix Cohen, The Erosion of Indian Rights, 1950-1953: A Case Study in Bureaucracy, 62 Yale L J 348 (1953).

${ }^{264} 25$ USC $§ \S 1301-1341$ (1982, and Supp 1986). The legislation had several provisions other than those related to rights of tribes against members; for example, one aspect of the legislative packet was to limit states' ability to assert jurisdiction over activities on Indian lands. Senator Sam Ervin, a Democrat of North Carolina, was centrally involved in the legislative effert on "civil rights". Beginning in 1961, Senator Ervin, with the help of his legislative assistant, Helen Scheirbeck (a member of the Lumbees), began hearings for what ICRA legislative history called "the most neglected minority group in the history of the Nation." Report of the Senate Judiciary Committee, S Rep No 721, 90th Cong, 1st Sess (Nov. 2, 1967) in 1968 USC CAN 1837-39, 1862-67. See Donald L. Burnett, Jr., An Historical Analysis of the 1968 'Indian Civil Rights' Act, 9 Harv J Leg 557, 574-82 (1972).

${ }^{265}$ The rights are enumerated at 25 USC $\$ 1302$; they include protection from interference with the free exercise of religion, from self-incrimination, from deprivations of property without compensation, from illegal searches and seizures, from cruel and unusual punishment, excessive bail, bills of attainder, and from denial of liberty or property without due process and denial of equal protection of "its" (i.e., a tribe's) laws. In addition, Congress protected criminal defendants' rights to a jury of not less than six persons and to confront and cross examine adverse witnesses. The "Indian Bill of Rights" is not identical to the federal constitutional provisions; for example ICRA does not prohibit the establishment of religion or require the provision of counsel in criminal proceedings. For discussion of whether ICRA rights should be interpreted in accordance with counterpart provisions in the federal constitution, see Duro v Reina, 821 F2d 1358, 1362 n 4 (9th Cir 1987) (en banc), cert granted, $109 \mathrm{~S}$ Ct 1930.

${ }^{268}$ See Indian Civil Rights Act, 25 USC $\S 81301-1303$ (1982 and Supp 1986). For differing descriptions of the legislative history, compare Justice Marshall's opinion for the Court with Justice White's dissent in Santa Clara Pueblo, 436 US at 49 and 72.

${ }^{267}$ See generally Note, Implication of Civil Remedies Under the Indian Civil Rights Act, 75 Mich L Rev 210 (1976). See also G. Kenneth Reiblich, Indian Rights Under the Civil Rights Act of 1968, 10 Ariz L Rev 617 (1968). 
once again. In 1968, President Johnson had termed Indians "the forgotten American," and in 1970, President Nixon's executive proclamation steered federal policies again toward tribal sovereignty. ${ }^{268}$ Stating that "[s]elf-determination among the Indian people can and must be encouraged without the threat of eventual termination," Nixon announced a legislative package to permit Indian tribes to administer federal service programs. ${ }^{269}$ Soon thereafter, justices appointed by President Nixon to the Supreme Court turned that institution's attention away from articulation of individual rights, away from implication of remedies from federal statutory schemes, ${ }^{270}$ and towards an emphasis on state sovereign powers. $^{271}$ In the 1978 Santa Clara Pueblo decision, the federal policy of tribal self-determination, ambivalence about women's rights, and the limited federal court willingness to imply remedies coalesced, and Julia and Audrey Martinez were told that the federal courts could not help them.

\section{Sovereignty and Jurisdiction.}

But federal court support for the principle of tribal sovereignty has limits as well. Just two months before deciding Santa Clara Pueblo, the Supreme Court held that Indian tribes lack authority to punish non-Indians who commit crimes on tribal reservations. Oliphant $v$ Suquamish Indian Tribe ${ }^{272}$ arose when two

${ }^{208}$ The Forgotten American, Message from the President of the United States, HR Doc No 90-272, 114 Cong Rec 5394-98 (March 6, 1968) (President Johnson); The American Indians, Message from the President of the United States, H Doc No 91-363, 116 Cong Rec 23131 (July 8, 1970) (President Nixon). President Reagan stated his administration's commitment to those policies. See Proclamation 5049 of April 14, 1983, 3 CFR 40 (1983); Statement of the President, January 24, 1983, in 19 Weekly Compilation of Presidential Documents (Fed Reg 1983); Proclamation 5577 of Nov. 24, 1986, 3 CFR 160 (1986).

269 Presidential Message on American Indians, H Doc No 91-363, 116 Cong Rec at 23132 (July 8, 1970). As noted at notes $234-35$ and accompanying text, the availability of federal benefit programs was one of the factors that triggered the lawsuit in the Martinez case.

${ }^{270}$ Compare Cort $v$ Ash, 422 US 66 (1975); Cannon v University of Chicago, 441 US 677 (1979); Texas Industries, Inc. $v$ Radcliff Materials Inc., 451 US 630 (1981); Middlesex Cty. Sewerage Auth. v Sea Clammers, 453 US 1 (1981); and Karahalios v National Federation of Federal Employees, 109 SCt 1282 (1989). A similar retrenchment has occurred in the implication of causes of action from the Constitution. See Chappell $v$ Wallace, 462 US 296 (1983); Bush v Lucas, 462 US 367 (1983); and U.S. v Stanley, 483 US 669 (1987).

${ }^{271}$ Younger $v$ Harris, 401 US 37 (1971) began a series of cases that limited federal courts' ability to consider issues pending before state tribunals. See Huffman v Pursue, Ltd., 420 US 592 (1975); Middlesex Ethics Comm v Garden State Bar Ass'n, 457 U.S. 423 (1982).

${ }^{272} 435$ US 191 (1978). Justice Rehnquist wrote the opinion for the Court; Justice Marshall, joined by Chief Justice Burger, filed a brief dissent, in which he argued that "[i]n the absence of affirmative withdrawal by treaty or statute, I am of the view that Indian tribes 
non-Indian residents of the Suquamish Tribe's reservation sought habeas corpus relief from criminal convictions in the tribal court. In a much criticized decision, the Supreme Court held that criminal jurisdiction to try non-Indians for crimes committed on an Indian reservation was "inconsistent" with the status of Indian tribes. ${ }^{273}$ While the Court drew upon a number of sources, its underlying assumption is that tribal sovereignty is not unbounded but limited - because the tribes are not fully another government but a dependent group. ${ }^{274}$ Justice Rehnquist's opinion for the Court stated that tribal powers were not "limited only by specific restrictions in treaties or congressional enactments"; tribal powers could not "conflict with [the] . . . overriding sovereignty" of the United States. ${ }^{275}$ Justice Rehnquist spoke of the United States' interest in protecting citizens (implicitly, non-Indian citizens) from "unwarranted intrusions on their personal liberty."276 While Justice Rehnquist stated that "some Indian tribal courts have become increasingly sophisticated and resemble in many respects their state counterparts," his concern was that tribal justice would not always comport with United States definitions of due process. ${ }^{277}$

Since Oliphant, the Court has had several occasions to delineate the respective jurisdictions of the federal, state, and tribal courts regarding litigation to which Indians are parties. The issues are made complex by federal statutes, some of which assert jurisdiction over "major crimes" by Indians on Indian land, ${ }^{278}$ some of

enjoy as a necessary aspect of their retained sovereignty the right to try and punish all persons who commit offenses against tribal law within the reservation." Id at 212.

${ }^{273} 435$ US at 208.

274435 US at 208-11. For an analysis of Oliphant, see Richard B. Collins, Implied Limitations on the Jurisdiction of Indian Tribes, 54 Wash L Rev 479 (1979). For criticism of Oliphant, see Catherine Baker Stetson, Decriminalizing Tribal Codes: A Response to "Oliphant", 9 Am Indian L Rev 51 (1981); Robert Laurence, "Martinez, Oliphant," and Federal Court Review of Tribal Activity under the Indian Civil Rights Act, 10 Camp L Rev 411 (1988); Williams, 1986 Wisc L Rev at 269-72 (cited in note 89); for criticism of both Oliphant and Santa Clara Pueblo, see Canby, 62 Wash L Rev at 8-10 (cited in note 100); for discussion of Oliphant-generated law enforcement problems, see Steven M. Johnson, Jurisdiction: Criminal Jurisdiction and Enforcement Problems on Indian Reservations in the Wake of "Oliphant", 7 Am Indian L Rev 291, 292 (1979) ("relatively minor infractions of state and tribal law, such as traffic offenses, trespasses, even petty thefts and simple assault, will probably never rouse the attention of a federal prosecutor").

275435 US at $209-210$.

278 Id at 210 .

273 Id at $210-12$.

${ }^{278}$ The Major Crimes Act of 1948, 62 Stat 758, codified at 18 USC $\S 1153$ (1982 and Supp IV 1986) was enacted in response to the Supreme Court's finding in Ex parte Crow Dog, 109 US 556 (1883), of a lack of jurisdiction to try an Indian accused of a crime against another Indian on Indian lands. 
which cede federal jurisdiction to some states if they exercise the option, ${ }^{278}$ and some of which - including the Indian Civil Rights Act of 1968 - could be read to permit tribal jurisdiction to be at least a first, if not a final, forum. ${ }^{280}$

The recent major jurisdictional cases have probed the relationships between non-Indians, who are either doing business with tribes or living on reservations, and Indians. From National Farmers Union Insurance Company $v$ Crow Tribe ${ }^{\mathbf{2 8 1}}$ and Iowa Mutual Insurance Company $v$ LaPlante, ${ }^{282}$ the rule has emerged that federal courts should not exercise civil jurisdiction over activities arising on tribal lands at least until after tribal remedies have been exhausted, and possibly not thereafter. ${ }^{283}$ While many issues about the overlapping jurisdictions remain open, ${ }^{284}$ federal courts stu-

279 See Act of August 15, 1953, Pub L No 83-280, 67 Stat 588 (1953). Analyzed in Carole E. Goldberg, Public Law 280: The Limits of State Jurisdiction over Reservation Indians, 22 UCLA L Rev 535 (1975).

${ }^{280}$ Santa Clara Pueblo, 436 US at 72.

${ }^{281} 471$ US 845 (1985). This lawsuit was in the federal courts by virtue of federal question jurisdiction; the issue arose under federal common law.

${ }_{282} 480$ US 9 (1987) (in federal court by virtue of diversity jurisdiction).

283 The issue is how to read a sentence in Justice Marshall's opinion for the Court in Iowa Mutual: "[u]nless a federal court determines that the Tribal Court lacked jurisdiction, however, proper deference to the tribal court system precludes relitigation of issues raised by the LaPlantes' bad-faith claim and resolved in the Tribal Courts." 480 US at 19. Charles Wilkinson's view is that "federal judicial review is extremely limited" - to the question of tribal court jurisdiction to hear the case; the "basic fairness of the tribal action is not subject to review in federal court." Wilkinson, 21 Creighton L Rev at 778 (cited in note 82). For unsuccessful efforts to limit the application of Iowa Mutual and LaPlante to instances when claims were pending in both tribal and federal courts, see U.S. $v$ Turtle Mountain Housing Auth., 816 F2d 1273, 1276 (8th Cir 1987). While the federal courts agree that they retain jurisdiction to determine if the invocation of tribal jurisdiction is appropriate, see Brown $v$ Washoe Housing Authority, 835 F2d 1327 (10th Cir 1988), the question is under what circumstances "deference" is not required and whether Little Horn Bank v Crow Tribal Court, 690 F Supp 919 (D Mont 1988), discussed in text at notes 329-34, is idiosyncratic. See also A. \& A. Concrete $v$ White Mountain Apache Tribe, 781 F2d 1411, 1417 (9th Cir 1986).

Another issue that future cases will have to explore is whether full faith and credit will be afforded, should efforts be made to enforce tribal court decisions in other forums. See Santa Clara Pueblo, 436 US at $66 \mathrm{n} 21$ ("Judgments in tribal courts, as to matters properly within their jurisdiction have been regarded in some circumstances as entitled to full faith and credit in other courts." (citations omitted)). See also Issues in Mutuality, prepared by the American Indian Lawyer Training Program, Inc. 10-12 (Nov 1976) (discussing the pressures on tribal courts to become "courts of record" under state law to have state courts enforce tribal court judgments); Red Fox and Red Fox, 542 P2d 918 (Or App 1975) (according full faith and credit to the decree of a tribal court in marriage dissolution).

284 One question is the extent to which a tribal court can exercise criminal jurisdiction over Indian nonmembers. Compare Greywater v Joshua, 846 F2d 486, 488 (8th Cir 1988), with Duro v Reina, 821 F2d 1358, 1361 (9th Cir 1987), cert granted, 109 S Ct 1930 (1989), for their interpretations of dicta that an Indian tribe "cannot try a nonmember in tribal court" in United States $v$ Wheeler, 435 US 313, 326 (1978) (which held that the "dual sovereignty" exception to double jeopardy permitted both tribal and federal courts to prose- 
dents and scholars will find the modes of analysis familiar. Federal court jurisdiction is understood to be intrusive to the decision making of another sovereign; rules of comity mandate deference to that other court system. ${ }^{285}$ Federal courts do not "lack" subject matter jurisdiction but, as a result of prudentially based comity doctrines, must defer to another court system. ${ }^{286}$

The Indian tribe comity cases offer more than familiar analytic exercises, for the differences between sovereigns - federal and tribal-enable an understanding of why courts' exercise of jurisdiction can be described as "jurispathic." The term is Robert Cover's ${ }^{287}$ and its meaning is that courts can kill law created by communities. For many of us who think about the interaction between federal and state systems, it is often difficult to perceive federal courts as jurispathic vis-a-vis states. Given federal regulatory structures in place since the New Deal and federal civil rights rulings, the differences between "New Jersey," "California," or "Virginia" justice and "federal" justice seem small, and the "harm" to any state, if federal courts "intrude," seems more theoretical than real. Federal and state lines have blurred, at least for those who move from state to state and often have affiliations with more than one jurisdiction. ${ }^{288}$

In contrast, as both the Santa Clara Pueblo and Oliphant

cute an Indian for the same offense). Recently, the Court held that tribal courts have exclusive jurisdiction in adoption cases involving children of tribal members who reside on the reservation. See Mississippi Band of Choctaw Indians v Holyfield, $109 \mathrm{~S} \mathrm{Ct} 1597$ (1989). See also Fisher $v$ District Court, 424 US 382 (1976) (state court lacked jurisdiction over adoption proceedings in which all parties were members of the Northern Cheyenne Tribe). For discussion of the jurisdictional confusion, see Barbara Atwood, Fighting Over Indian Children: The Uses and Abuses of Jurisdictional Ambiguity, 36 UCLA L Rev 1051 (1989); Michael J. Dale, Tribal Court Civil Jurisdiction over Reservation-Based Claims: The Long Walk to the Courthouse, 66 Or L Rev 753 (1987) (tort and contract issues); Kevin Gover, Jurisdiction: Conflicts of Law and the Indian Reservation: Solutions to Problems in Indian Civil Jurisdiction, 8 Am Indian L Rev 361 (1980); Richard M. Brimsrud, Doing Business on an Indian Reservation: Can the Non-Indian Enforce his Contract with the Tribe?, 1981 BYU L Rev 319; James W. Zion, Harmony Among the People: Torts and Indian Courts, 45 Mont L Rev 265 (1984).

${ }^{285}$ See, for example, Younger v Harris, 401 US 37 (1971).

${ }^{286}$ See, for example, Wellman v Chevron U.S.A., Inc., 815 F2d 577, 578 (9th Cir 1987) (upholding dismissal of lawsuit but correcting trial court's reasoning. "The dismissal should have been based on comity, rather than lack of subject matter jurisdiction.").

${ }^{287}$ Robert M. Cover, The Supreme Court, 1982 Term - Foreword: Nomos and Narrative, 97 Harv L Rev 4, 40 (1983).

${ }^{288}$ Some do insist upon the distinctiveness of states or regions. See E. Grady Jolly, Feelings for Flem, Faulkner and Federalism, 4 Miss Coll L Rev 217, 224 (1984) ("The Faulkner lawyer had a general antipathy toward the federal government . . . because it threatened the distinctiveness of the South; ... . because it undermined the responsibility of individuals and localities to take care of their own wrongs and injustices"). 
opinions insist (albeit drawing different conclusions), Indian tribes are "other." Their culture and norms are not federal culture and norms; their rules are theirs. Given the possible divergences in culture between tribal modes of governance and federal norms, the use of jurisdiction as a means of control is more apparent than the claimed interference when federal courts preclude state court decision making. ${ }^{289}$ Jurispathic courts seem not an exaggeration but a real threat; federal court reluctance to exercise jurisdiction seems like an appropriate response to a claim that these people really do have a federally recognized place as "not federal."

But that place is unevenly respected. In some instances, federal court rules accord greater deference to tribal courts than to state courts, while in others, less solicitude for tribal authority is expressed. For example, some forms of comity, in which a federal court defers to a state court, are premised upon an assumption that the state court will apply federal law; the explicit vision is that a state court is equal to the federal court in fidelity to and enforcement of federal norms. ${ }^{290}$ Further, the state court decisions on federal law can, at least in theory, be reviewed by the United States Supreme Court. ${ }^{291}$ In contrast, when federal courts defer to tribal courts under both Santa Clara Pueblo and Iowa Mutual Insurance $v$ LaPlante, the tribal courts may not always follow federal law ${ }^{292}$ and, whether obliged to or not, their decisions in noncriminal cases are not reviewable by the federal courts. ${ }^{293}$ The Oliphant case, however, exemplifies the other version - when federal courts are less deferential to tribal courts than to state courts.

289 See, for example, the Supreme Court's discussion in Fisher v District Court, 424 US 382 (1976) (describing federal policy of Indian tribe control over affairs on Indian Reservations).

280 "[T]here is 'no intrinsic reason why the fact that a man is a federal judge should make him more competent, or conscientious, or learned with respect" " to federal constitutional rights than a state judge. Stone v Powell, 428 US 465, 494 n 35 (1976) (citation omitted).

291 Absent an independent and adequate state ground for decisions. See Michigan $v$ Long, 463 US 1032 (1983).

${ }^{292}$ In Santa Clara Pueblo, the Court noted that the Pueblo conceded that ICRA "modifies the substantive law applicable to the tribe." 436 US at 58. The Court further stated that ICRA "has the substantial and intended effect of changing the law which these [tribal] forums are obliged to apply." Id at 65 . Yet the Court also stated that especially in "a civil context," resolution of statutory issues under ICRA "will frequently depend on questions of tribal tradition and custom which tribal forums may be in a better position to evaluate than federal courts." Id at 71.

${ }^{203}$ Canby, 62 Wash L Rev at 10 (cited in note 100). Mechanisms other than federal court oversight exist to enforce the provisions of the ICRA. On the role of BIA enforcement, see Alvin J. Ziontz, After "Martinez": Civil Rights Under Tribal Government, 12 UC Davis L Rev 1 (1979). 
Under Oliphant, tribes cannot enforce their criminal laws against non-Indians but must instead depend upon other sovereigns' law enforcement interests. ${ }^{294}$ Yet, when criminal defendants in state court come to federal court to assert protection from state prosecution, the federal court declines - because of the centrality of criminal law to the states as "sovereign."

\section{Tribal Courts, Federal Courts, and State Courts.}

Doctrines of deference to other court systems assume that those court systems are "other." Just as the 1939 membership ordinance at issue in Santa Clara Pueblo must be seen not as a pure artifact of Santa Clara Pueblo culture but as a product of the interaction between Santa Clara Pueblo and the United States, so a closer look at the Indian tribal courts reveals many aspects of their operation to be a product of the interaction between tribal customs and the Bureau of Indian Affairs, the Department of Interior, and federal Indian policy.

Many commentators have described the tribal courts, ${ }^{286}$ and I will simply sketch the outlines. The 1883 case of Ex Parte Crow $D g^{297}$ is often credited with bringing attention to Indian tribal dispute resolution. The federal court for the Territory of Dakota convicted an Indian for the murder of another Indian on Indian lands. The Supreme Court interpreted the governing statutes and treaties as not authorizing federal jurisdiction and therefore voided the conviction. ${ }^{288}$ In response, in 1884 , the Secretary of Interior is-

${ }^{204}$ See Oliphant $v$ Schlie, 544 F2d 1007, 1013 (9th Cir 1976) (Tribe sought local, county, and federal assistance for protection during upcoming celebration but without success: "Without the exercise of jurisdiction by the Tribe and its courts, there could have been no law enforcement whatsoever on the Reservation during this major gathering ....).

295 Younger $v$ Harris, 401 US 37 (1971). While Younger was a criminal case, its doctrine has been expanded to apply to non-criminal proceedings. See, for example, Ohio Civil Rights Com'n. v Dayton Christian Schools, Inc, 477 US 619 (1986). Federal concerns for state enforcement of criminal laws have been partially responsible for restrictive interpretations of federal officials' statutory removal rights. See Mesa v California, 109 S Ct 959, 969 (1989) ("We are simply unwilling to credit the [federal] Government's ominous intimations of hostile state prosecutors and collaborationist state courts interfering with federal officers ....").

${ }^{288}$ See generally Tribal Court Survey, pt II at 11 (cited in note 148); Clinton, 18 Ariz L Rev at 553-63 (cited in note 108); Pommersheim, 18 NM L Rev 49, 50 (cited in note 218); Pommersheim and Pechota, 31 SD L Rev 553 (cited in note 28); James W. Zion, Harmony Among the People: Torts and Indian Courts, 45 Mont L Rev 265 (1984).

287109 US 556 (1883), superseded by Major Crimes Act, 18 USC § 1153 (1982). For additional discussion of criminal jurisdiction, see Clinton, 18 Ariz L Rev 503 (cited in note 108).

${ }^{283}$ Crow Dog, 109 US at 570 (determining the validity of $\S 2146$ of the Revised Statutes, which "excludes from the jurisdiction of the United States the case of a crime commit- 
sued regulations establishing "courts of Indian offenses" and staffing those courts with Indian judges. ${ }^{299}$ The purpose of these courts was expressly jurispathic; to "civilize" tribes by banning tribal custom and imposing federal norms. ${ }^{300}$ In 1885, Congress passed the "Major Crimes Act," ${ }^{301}$ which conferred federal jurisdiction over Indians in Indian country for seven specified felonies. The Supreme Court upheld that grant of jurisdictional control as an appropriate exercise of federal guardianship powers over Indians. ${ }^{302}$

Two mechanisms were used to infuse federal norms into Indian dispute resolution. The first was divesting tribes of jurisdiction over issues deemed outside their competence, either by making that jurisdiction federal ${ }^{303}$ or by turning jurisdiction over to the states. ${ }^{304}$ The second was to instruct and to influence tribes about how to exercise what jurisdiction remained theirs. ${ }^{305}$

During the late nineteenth and early twentieth centuries, ${ }^{306}$ federal control over tribal courts was pervasive. By 1926, seventy Indian judges were paid by federal funds and worked in Indian

ted in the Indian country by one Indian against the person or property of another Indian"). See also Robert N. Clinton, Development of Criminal Jurisdiction Over Indian Lands: The Historical Perspective, 17 Ariz L Rev 951 (1975).

${ }^{290}$ See Tribal Court Survey at 17 (cited in note 148).

300 Id at 17-18; Clinton, 18 Ariz L Rev at 553 (cited in note 108). The tribal justice system had required the Indian to support the victim's dependent relatives (in some sense a predecessor of the federal Victim and Witness Protection Act, 18 USC $\S \S 1503$ et seq (1982)), and that sanction had inspired or been used to legitimate hostility towards Indian customs. See Newton, $132 \mathrm{U} \mathrm{Pa} \mathrm{L}$ Rev at $212 \mathrm{n} 81$ (cited in note 99).

so1 As amended, now codified at 18 USC \$ 1153 (1982).

${ }^{302}$ United States v Kagama, 118 US 375, 383-84 (1886). See also United States $v$ Antelope, 430 US 641 (1977) (again upholding federal criminal jurisdiction); United States $v$ Wheeler, 435 US 313, 330-31 (1978) (upholding the right of federal prosecutors to try an Indian who had been prosecuted in the tribal court).

${ }^{303}$ For limits on tribal courts power in criminal matters, see 25 USC $\S 1302$ (7) (1986) (punishment cannot exceed fines of $\$ 5000$ or prison sentences of one year or both). See generally Richard B. Collins, Implied Limitations on the Jurisdiction of Indian Tribes, 54 Wash L Rev 479 (1979) (discussing history of tribal jurisdiction and forecasting that tribal authority would be sustained over non-Indians in civil litigation).

${ }^{304}$ For example, in 1953, during the era of "termination" of federal recognition of tribes, Congress enacted Public Law 280, which permitted state courts to assert jurisdiction over Indian tribes. Act of August 15, 1953, Pub L No 83-280, 67 Stat 588, upheld in Washington $v$ Yakima Indian Nation, 439 US 463 (1979).

sos William T. Hagan, Indian Police and Judges: Experiments in Acculturation and Control (Yale, 1966).

${ }^{30}$ See Kickingbird, 13 Am Crim L Rev at 675-90 (cited in note 215); Francis Paul Prucha, ed, Americanizing the American Indians: Writings by the "Friends of the Indian" 1880-1900 at 295-305 (Harvard U, 1973) (reprinting 1882 directives of Henry M. Teller, Secretary of the Interior, on "courts of Indian Offenses" in 1882, and regulations for those courts promulgated by Thomas J. Morgan in 1883). 
courts run pursuant to Interior Department regulations. ${ }^{307}$ After the 1934 enactment of the Indian Reorganization Act, the Department of the Interior provided model regulations for tribes to structure justice systems. Although some tribes retained their traditional tribal courts, many tribes adopted court structures based upon the Interior Department regulations. These courts have become known as "CFR courts," after the sections of the Code of Federal Regulations that set forth the court procedures, the selection and removal of judges, and a compilation of "Indian Tribal Offenses." 308 Indian justice rules "were copied verbatim or patterned to a considerable extent upon the [then] new Departmental rules." ${ }^{309}$ Indeed, some Indian tribes adopted Interior Departmentinspired codes and constitutions that limited Indian court jurisdiction and made Indian tribal decisions dependent upon approval by the Secretary of the Interior. ${ }^{310}$ The enactment, in 1968, of the Indian Civil Rights Act exerted additional pressures to adopt the United States' modes of dispensing justice. As one group of commentators who surveyed tribal courts in the late 1970s describes: "[T]he 1968 Indian Civil Rights Act implies to many Indians that self-determination is acceptable only to the extent that tribes develop sophisticated, anglicized tribal court systems." ${ }^{311}$ Only a few tribes followed customary law, while the majority adopted justice mechanisms like those in the United States - albeit with extremely limited funding and resources. ${ }^{312}$

${ }^{307}$ Tribal Court Survey at 20-21 (cited in note 148),

${ }^{308} 25$ CFR $\S 11$ et seq; Pommersheim, $18 \mathrm{NM} \mathrm{L} \mathrm{Rev} \mathrm{at} \mathrm{56-57} \mathrm{(cited} \mathrm{in} \mathrm{note} \mathrm{218)}$ (" 'CFR' courts .... are the successors to the Bureau of Indian Affairs' Courts of Indian Offenses, ... [and] are ... widely regarded as entities subject to extensive and excessive Bureau of Indian Affairs control and influence"). See also Clinton, 18 Ariz L Rev at 557-64 (cited in note 108).

${ }^{309}$ Tribal Court Survey at 24-27 (cited in note 148).

3to Id at 27-28. See also Moapa Band of Paiute Indians, 747 F2d 563 (1984).

311 Tribal Court Survey at 35 (cited in note 148).

${ }^{312}$ Id at 36-54. As of 1975 , two thirds of seventy-three chief judges reported earning $\$ 8000$ or less annually. Id at 64 . See also Lis Wiehl, Indian Courts Struggling to Keep Their Identity, NY Times B7 (Nov 4, 1988); Richard B. Collins, Indian Courts in the Southwest, 63 ABA J 808, 809-10 (1977).

Several training manuals provide instruction on procedures. See, for example, Ralph W. Johnson and Jay V. White, Cases and Materials for Indian Court Judges (National American Indian Court Judges Assoc., 1976) (a casebook to provide "legal education" to Indian Court judges; the cases will be a "useful starting point," but judges should "make an independent judgment" in each case. Id at 3-4); Ralph Johnson and Sue Crystal, Criminal Law \& Procedure for Indian Tribal Courts (Natl Am Indian Ct Judges Assoc, 1977) (describing the role of the judge, appropriate procedures). These manuals were updated in John W. Milne and Ralph W. Johnson, Criminal Law for Indian Courts (Natl Am Indian Ct Judges Assoc, 1980) (summarizing evidentiary rules, Miranda rights, burdens and presumptions, 
Yet these tribal courts are not simply federal products, for they developed from an interaction between federal regulation and Indian tribal customs. As a consequence, many Indian tribal courts have aspects that are not so familiar to those schooled in United States' court practices. Most notably from the perspective of the United States, federal traditions of separation of powers are not commonplace. Some commentators report that tribal councils influence tribal court decision making in a variety of ways, including judicial selection, retention, and recall. ${ }^{313}$ Further, in some instances, tribal councils act as appellate bodies as well as executive decision makers. The sources of law, ${ }^{314}$ permissible styles of argument, and structure of the proceedings ${ }^{315}$ may vary substantially from what practitioners have come to expect in federal courts. ${ }^{318}$

Thus, when the federal courts require litigants to submit to tribal courts in the name of tribal sovereignty, many of those court systems have been framed and regulated by the BIA but also maintain proceedings and procedures at some variance from federal and state courts. The question is whether the federal government will tolerate such deviations by respecting and deferring to tribal court jurisdiction, or whether federal rules of deference and

search and seizure rules); and in Milne and Johnson, Criminal Procedure for Indian Courts (Natl Am Indian Ct Judges Assoc, 1980) (with a section entitled "the Necessity of Independence" of the judge, id at 20-38; and recommending that the "judicial branch should be independent of other parts of the tribal government whenever consistent with tribal custom and tradition." Id at 23.).

${ }^{323}$ Gregory Schultz, The Federal Due Process and Equal Protection Rights of NonIndian Civil Litigants in Tribal Courts after "Santa Clara Pueblo v. Martinez", 62 Denver U L Rev 761, 769 (1985) (citing also the Tribal Court Survey). But see Michael Taylor, Modern Practice in Tribal Courts, 10 U Puget Sound L Rev 231, 262 (1987) ("interference by other branches of tribal government is a constitutional worry rather than a practical problem"); Pommersheim, $18 \mathrm{NM} \mathrm{L} \mathrm{Rev} \mathrm{at} 66$ (cited in note 218) (increasingly there is a move toward "de facto, if not de jure separation of powers").

314 Zion, 45 Mont L Rev at 269-73, 275-79 (cited in note 284).

315 Pommersheim, 18 NM L Rev at 61-64 (cited in note 218). See also Ralph W. Johnson and Kathy Imig Perkins, The Northwest Experience, 63 ABA J 811, 812 (1977) (many tribes have "completely revamped" their codes from those that had been in effect under the BIA era); James W. Zion, The Navajo Peacemaker Court: Deference to the Old and Accommodation to the New, 11 Am Indian L Rev 89 (1983) (relying upon traditional mediation). An empirical study, comparing tribal courts to local state courts of similar size and caseload, would clarify how much variance actually exists.

s16 Pommersheim, 18 NM L Rev 49 (cited in note 218). Apparently, there are also tensions within Indian tribes about the legitimacy of the tribal court processes; some accuse the courts of being " 'white men's' creations," while others believe that the courts are "illegitimate because they fall, or appear to fall, far below recognized state and federal standards." Id at 60. See also Pommersheim's discussion of one tribal court judge's efforts to explain his court to the communities in the tribe. Id at 61. See generally Pommersheim and Pechota, 31 SD L Rev 553 (cited in note 28). 
comity depend upon the similarity between the two court systems.

\section{Federal Oversight via Relitigation.}

One vehicle for federal review is the habeas corpus provision of the Indian Civil Rights Act; by that provision, Congress authorized federal courts to consider "the legality of . . . detention by order of an Indian tribe." 317 In August 1988, Senator Orrin Hatch, who is often identified with legislation aimed at stripping, rather than conferring, federal court jurisdiction, ${ }^{318}$ suggested that an additional route to the federal court be provided. He introduced S 2747, entitled "The Indian Civil Rights Act Amendments of 1988."319 The proposed amendments would overturn Santa Clara Pueblo to a large extent by authorizing jurisdiction in the federal courts over "civil rights actions alleging a failure to comply with rights secured" by the legislation. ${ }^{320}$ The Hatch proposal requires exhaustion of tribal court remedies and then permits return to the federal courts for "any aggrieved individual ... or the Attorney General on behalf of the United States." ${ }^{212}$ Such plaintiffs could obtain declaratory and equitable relief against tribes or their officials for a variety of failings of tribal court decision making, including the failure of a tribal court to be "fully independent from the tribal legislative or executive authority," the failure to "resolve the merits of the factual dispute," the failure to "adequately develop material facts," and the failure to afford "a full and fair hearing." ${ }^{322}$ In short, the proposed legislation would permit exten-

31725 USC $\S 1303$ (1982).

${ }^{318}$ See, for example, S 37, 99th Cong, 1st Sess (Jan 1, 1985) (restricting lower federal court jurisdiction to issue orders about busing in school desegregation cases); S 583, 97th Cong, 1st Sess (Feb 2, 1981) (to eliminate Supreme Court appellate jurisdiction over cases challenging state laws that restrict access to abortions).

${ }^{319}$ See 134 Cong Rec S 11652 (Aug. 11, 1988). See Robert A. Williams, Documents of Barbarism: The Contemporary Legacy of European Racism and Colonialism in the Narrative Traditions of Federal Indian Law, 31 Ariz L Rev 237 (1989) (criticizing the proposal for generalizing upon a few isolated incidents and for assuming that differences between tribal and federal justice mean that tribal justice is inferior).

${ }_{320}$ S 2747 \& 204(a), 134 Cong Rec S11656 (Aug 11, 1988). On March 6, 1989, Senator Hatch reintroduced this bill, retitled the Indian Civil Rights Act Amendments of 1989, S 517, 135 Cong Rec S 2186.

s21 S 2747, 134 Cong Rec S 11656.

${ }^{322}$ Id. For discussion of current means (without legislative changes) to avoid the Santa Clara Pueblo rule, see Kevin Gover and Robert Laurence, Avoiding "Santa Clara Pueblo v. Martinez": The Litigation in Federal Court of Civil Actions under the Indian Civil Rights Act, 8 Hamline L Rev 497 (1985). For suggestions similar to those of Senator Hatch for legislation overruling Santa Clara Pueblo, see Schultz, 62 Denver U L Rev at 783-87 (cited in note 313) (advocating "appeals" to federal trial courts of adverse decisions at the tribal court level). 
sive federal court "oversight" of or "intrusion" into tribal courts.

The Hatch proposal has a familiar ring to those versed in federal court jurisprudence. In many respects, his bill is modeled after federal habeas corpus legislation, 28 USC § 2254. Section 2254 provides for federal court jurisdiction of alleged violations of federal constitutional rights in state court adjudication of criminal defendants' rights. After petitioners have exhausted state court remedies, federal judges may review state court decisions if "the merits of the factual dispute were not resolved";323 the "material facts were not adequately developed at the State court hearing";324 or "the factfinding procedure employed by the State court was not adequate to afford a full and fair hearing." 325 The reasons animating federal review of tribal decisions track those given for federal court review of state court decisions - fear that the "other" forum will not accord the process that the federal government believes is necessary to justify the exercise of coercive enforcement powers. However, unlike federal habeas corpus legislation, no representatives of the tribes will have the power to vote on enactment of the Hatch legislation.

Senator Hatch has co-sponsored legislation that would limit federal court jurisdiction over habeas corpus petitions. ${ }^{326}$ In contrast, his proposed amendments to the Indian Civil Rights Act S 2747 will increase federal court jurisdiction over claims that Indian tribunals deprived individuals of rights. When introducing S 2747, Senator Hatch said it was needed to check power and to protect against civil rights abuses, especially when non-Indians were involved. ${ }^{327}$ Senator Hatch also voiced strong objection to dif-

s23 28 USC $\S 2254(d)(1)(1982)$.

s24 28 USC \& 2254 (d)(3).

${ }^{325} 28$ USC $\S 2254(\mathrm{~d})(2)$. Other provisions of the Hatch proposal also track $\S 2254$. Compare $\$ 2254(\mathrm{~d})(6)$ with $\mathrm{S} 2747(\mathrm{c})(7)$ and $\S 2254(\mathrm{~d})(3)$ with $\mathrm{S} 2747(\mathrm{c})(6)$.

${ }^{328}$ See, for example, S 1970, 100th Cong, 1st Sess (1987), 133 Cong Rec S 18412 (Dec 18, 1987); S 260, 100th Cong, 1st Sess (1987); S 2301, 99th Cong, 2d Sess (1986), 132 Cong Rec S 4211 (April 14, 1986); S 238, 99th Cong, 2d Sess (1986), 131 Cong Rec S 481 (Jan 22, 1985). These bills sought to impose statutes of limitation on habeas filings and increased other procedural barriers to habeas corpus relief. In support of S 2301, Senator Hatch stated that the "abuse of the habeas process is making a mockery of the principles of finality and certainty in the American judicial system." 132 Cong Rec S 4212 (April 14, 1986).

${ }^{327} 134$ Cong Rec at S 11654 (Aug 11, 1988). The U.S. Civil Rights Commission has held a series of hearings to investigate alleged "civil rights" abuses. See Hearings Before the U.S. Commission on Civil Rights: Enforcement of the Indian Civil Rights Act (Washington, DC, Jan 28, 1988; Portland, Oregon, March 31, 1988; Flagstaff, Arizona, July 20, 1988 and Aug 13-14, 1987; Rapid City, South Dakota, July 31-Aug 1, Aug 21, 1986). See also Robert N. Clinton, Speech on Tribal Courts and Civil Rights: Prepared for Delivery at AALS Convention 1 (AALS Native American Rights Section, January 8, 1989) ("AALS Speech") ("I 
ferences he perceived between tribal justice and federal justice. $\mathrm{He}$ was particularly concerned about a lack of separation of powers about tribal judiciaries more obviously connected to the tribal councils than is customary in the federal system. ${ }^{\mathbf{3 2 8}}$

Senator Hatch's introductory comments to the legislative proposal illustrate his concerns. He discussed in detail the case of Little Horn State Bank v Crow Tribal Court, ${ }^{329}$ which involved a bank's effort to obtain a forklift from a defaulting debtor. ${ }^{330}$ There, despite United States Supreme Court mandates of deference to tribal court decision making, a federal trial judge declined to defer and instead enjoined enforcement of the tribal court order protecting the alleged debtor. Senator Hatch quoted at length from the federal court opinion, in which the judge characterized the tribal court as a "sort of 'kangaroo court' [that] has made no pretense of due process or judicial integrity. ... It would appear that the Crow Tribal government changes judges at a whim, to the detriment of non-Indian litigants, and of the Tribe. As a result, the Tribal Court lacks any continuity and uniform precedent which is the foundation of our judicial system. . . . If the Crow Tribe wishes to earn the respect and cooperation of its.non-Indian neighbors, it must do more to engender that respect and cooperation. . . ."331

want to focus attention on the investigation, some might call it an inquisition, into tribal governmental compliance with the Indian Civil Rights Act that the United States Civil Rights Commission has conducted for the last two and a half years") (on file with the University of Chicago Law Review).

${ }^{328}$ Senator Hatch stated: "Real power in many tribal government rests with the tribal council or legislative branch. ... Where courts do exist, they are often a creation of the tribal council and therefore subject to and dependent on the council." 134 Cong Rec at S11652 (Aug 11, 1988).

${ }^{329} 690$ F Supp 919 (D Mont 1988), vacated pursuant to parties' stipulation, 708 F Supp 1561 (1989). Senator Hatch also discussed (at 134 Cong Rec S11654) Shortbull v Looking Elk, 677 F2d 645, 650 (8th Cir 1982) (no federal cause of action when non-enrolled tribal member was denied permission by Tribal Executive Committee to run for tribal office and tribal judge who ruled he could run was removed from office); and Dry Creek Lodge Inc. $v$ Arapahoe and Shoshone Tribes, 623 F2d 682, 685 (10th Cir 1980) (distinguishing Santa Clara Pueblo and permitting federal litigation because dispute involved non-Indians contesting tribes' closure of access to their guest lodge).

${ }^{\text {sso }}$ For discussion of the role of tribal courts as small claim courts for non-Indian creditor collections, see Jesse C. Trentadue, Tribal Court Jurisdiction over Collection Suits by Local Merchants and Lenders: An Obstacle to Credit for Reservation Indians?, 13 Am Indian L Rev 1, 47 (1987) ("Although those attorneys who have practiced before a tribal court do not express overwhelming dissatisfaction with the Indian court system, a majority of all attorneys surveyed had a low opinion of tribal courts ... [which was] transmitted to banks, savings and loans, and other business clients these counsel represent").

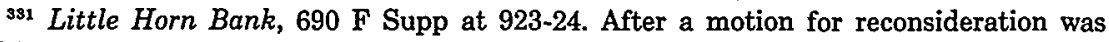
filed in that case, the parties agreed to a settlement. Conversation with Natasha J. Morton, counsel for Little Horn State Bank (January, June 1989). Compare Shortbull v Looking Elk, 
I know nothing of the merit of the trial judge's description of the Crow Tribal Court's methods. ${ }^{332}$ Nor do I know whether the informality and the connection between tribal council and tribal judge that the federal court found offensive are so very different from small town state court proceedings, ${ }^{333}$ or how frequently such informality is found in tribal courts. What is plain is that the federal trial judge found the Crow tribal processes very different from those that he identified as essential to "judicial integrity" and that, given the absence of similarity between the two systems, the federal judge declined to permit the tribal ruling to stand..$^{334}$ Further, the federal judge was remarkably unrestrained in his language; he did not employ the polite discourse common when federal judges speak of state court decision making. The Hatch proposal builds upon the assumptions of the Little Horn Bank case; the proposal would authorize the position taken by the federal judge in that case. Like federal habeas corpus review of state court decisions, the Hatch proposal is designed to insure that another sovereign's court system follows the norms of the federal sovereign. Both the habeas statute and the Hatch proposal are efforts to assimilate-to permit "independence" only upon condition that the "other" process mirrors the federal one.

Of course, in federal/state habeas corpus jurisprudence, some

677 F2d at 650 (finding no federal cause of action and concerned about federal court inability to enforce ICRA).

${ }^{332}$ According to papers filed by the tribe, the Bureau of Indian Affairs did not give its approval (as required by 25 USC $\$ 81$ ) to the tribe's selection of an attorney and hence the tribe was unable to have an attorney to present its side of the case to the federal district court. Rule 59 and 60 Motion [to set aside the judgment] of the Crow Tribal Court (July 29, 1988) (on file with the University of Chicago Law Review). For praise of tribal courts, see Clinton, AALS Speech at 9-10 (cited in note 327) ("What is most remarkable about the twenty year history of the enforcement of the Indian Civil Rights Act is ... how close [tribal governments] have come in a very short twenty year[s] . . to reaching a level of development in enforcement of civil liberties that took almost a century and half of development in federal and state courts").

3s3 See also Collins, $63 \mathrm{ABA} J$ at 808,810 (cited in note 312 ).

${ }^{334}$ Other federal judges have also criticized Indian tribal court processes. See, for example, Greywater v Joshua, 846 F2d 486, 489 (8th Cir 1988) (exhaustion of tribal remedies not required for habeas corpus petitioners, who were members of Turtle Mountain Band of Chippewa Indians and who were defending criminal charges in the Devils Lake Sioux Tribal Court). The Greywater court stated, id at 488, that the Sioux Tribal Court had denied the defendants' motion to dismiss "without a hearing and without a record" (an event, I must note, not without precedent in the federal and state court systems). The court then commented that "[e]ncouraging the exercise of sovereignty by a tribal court through development and upgrading of its procedures is not served where the tribal court itself fails to do so." Id at 488-89. See also Schultz, 62 Denver U L Rev at 778-82 (cited in note 313) (lower court cases concerned about the limits of federal court jurisdiction after Santa Clara Pueblo). 
of us may well cheer when the federal government exerts its pressures to require state courts to treat members of minorities fairly, to require enforcement of the Fourth, Fifth, and Sixth amendments, and to demand that procedures accord with that which is deemed "just and fair." Wsss What must be recognized is that, in federal habeas corpus jurisdiction, the exercise of federal power is aimed at revising the underlying decision or the decision making processes to conform to what federal courts deem appropriate. The question that the Hatch legislative proposal poses is whether the federal government should attempt to require tribal courts to "imitate the interpretive strategies and canons displayed in federal and state settings."

\section{The Lessons Learned}

\section{A. Familiar But Altered Themes}

Those familiar with federal courts' jurisprudence can easily feel at home with federal Indian law, despite its absence from the canon. Federal habeas corpus jurisdiction expanded when federal courts and Congress perceived state courts as inhospitable to enforcement of federal rights. ${ }^{337}$ Relitigation of state court civil rights decisions expanded, briefly, when federal courts questioned state courts' adherence to federal rights enforcement ${ }^{338}$ and receded in face of claims of state court "parity." ${ }^{339}$ Federal court relitigation

${ }^{335}$ Compare Stone $v$ Powell, 428 US 465 (1976) with Kaufman v United States, 394 US 217 (1969).

sse Pommersheim, 18 NM L Rev at 70 (cited in note 218) (tribal courts should not have to "blindly imitate" and that, when the "interpretive strategies and goals" of tribal courts differ, tribes should consciously decide what their differing choices are and why). See also Williams, Documents of Barbarism, (cited at note 319) (rejecting the assertion of federal power over tribes and describing the assimilationist discourse as racist).

337 William F. Duker, A Constitutional History of Habeas Corpus 248-273 (Greenwood Press, 1980). See the evolution from Frank v Magnum, 237 US 309 (1915), and Moore $v$ Dempsey, 261 US 86 (1923), to Fay $v$ Noia, 372 US 391 (1963). Compare Wainwright $v$ Sykes, 433 US 72 (1977).

${ }^{338}$ Until Allen v McCurry, 449 US 90 (1980), held that 42 USC § 1983 should not be treated as an exception to full faith and credit rules, some lower federal courts had permitted such relitigation. Under current interpretations of the interaction between federal rights, state preclusion law, and 28 USC $\$ 1738$, some claims can still be considered in federal court. See Haring $v$ Prosise, 462 US 306 (1983) and McDonald $v$ West Branch, Mich., 466 US 284 (1984).

330 See generally Burt Neuborne, The Myth of Parity, 90 Harv L Rev 1105 (1977). Compare the comments of Erwin Chemerinsky, Parity Reconsidered: Defining a Role for the Federal Judiciary, 36 UCLA L Rev 233 (1988) and Martin H. Redish, Judicial Parity, Litigant Choice and Democratic Theory: A Comment on Federal Jurisdiction and Constitutional Rights, 36 UCLA L Rev 329 (1988). 
of claims of discriminatory employment practices, decided adversely in state and federal administrative agencies, is still available. $^{340}$ If Little Horn Bank is illustrative of federal courts' attitudes, or if the Hatch proposal is enacted, federal court relitigation of tribal court decisions may similarly expand, as federal judges and members of Congress perceive tribal courts to be inhospitable to United States forms of procedure and to the enforcement of federal rights. ${ }^{341}$

Again and again, in the contexts of both state and tribal courts, we watch the interplay between multiple court systems, between expansion and contraction of jurisdiction, sometimes to affirm norms of diversity and, at other times, to encourage assimilation by the application of nationwide norms. The state/federal and Indian tribe/federal patterns are not identical, but at many points, doctrine and explanation overlap.

More, however, than familiar themes are evident. From the reiteration of patterns, the enormous power of the federal system in federal/state and in federal/tribe relations - emerges with greater clarity. While some cases in current federal courts' jurisprudence may question some aspects of state sovereignty, ${ }^{342}$ the

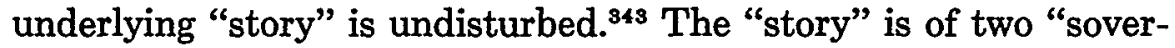
eigns," state and federal, each with a discrete identity and joined as co-venturers, with the federal government having supreme powers only to the extent granted by the Constitution. ${ }^{344}$ The inclusion of Indian tribe cases challenges some of this narrative. Listen to Justice Marshall in Santa Clara Pueblo: "Congress has plenary au-

s40 Title VII, 42 USC $\S \S 2000 \mathrm{e}$ et seq (1982). See also Kremer $v$ Chemical Construction Corp, 456 US 461 (1982) (relitigation may only occur if the claimant has not sought state court review of state agency decisions); University of Tennessee $v$ Elliot, 478 US 788 (1986) (unreviewed state administrative factfinding could have preclusive effect on claims brought under $\S 1983$, but not under Title VII).

s41 It will be interesting to see whether a federal common law of commercial transactions between Indians, Indians who are members of different tribes, and non-Indians results. See Swift $v$ Tyson, 41 US 1 (16 Pet) (1842), overruled by Erie R. Co. $v$ Tompkins, 304 US 64 (1938).

${ }^{342}$ See, for example, Garcia v San Antonio Metropolitan Transit Authority, 469 US 528 (1985).

34 See Smith, Contingencies of Value at 51 (cited in note 37) ("However much canonical works may be seen to 'question' secular vanities such as wealth, social position, and political power, ... they would not be found to please long and well if they were seen radically to undercut establishment interests or effectively to subvert the ideologies that support them.") (emphasis in original).

sis See, for example, the scholarship aimed at creating structural limits to federal authority. Rapaczynski, $1985 \mathrm{~S} \mathrm{Ct} \mathrm{Rev} 341$ (cited in note 79); Robert F. Nagel, Federalism as a Fundamental Value: National League of Cities in Perspective, $1981 \mathrm{~S} \mathrm{Ct} \operatorname{Rev} 81$. 
thority to limit, modify or eliminate the powers of local self-government which the tribes otherwise possess." 348 The question is whether such a statement can also be made in the context of federal/state relations. Federal power over the states is not "legally" as "plenary" as it is over the Indian tribes, but finding the limits of federal power over states has proven difficult. Federal infusions of funds, federal joint programs, federal incentive grants, federal court commerce clause review, and federal lawmaking powers overwhelm notions of states as self-defined, autonomous, "sovereign" actors. In Garcia $v$ San Antonio Metropolitan Transit Authority, ${ }^{348}$ the Supreme Court rejected state efforts to obtain the Court's protection from Congress. States were told to make their arguments to Congress and then to be bound by its decision making. ${ }^{347}$ What is baldly stated in cases involving Indian tribes about the power of Congress is implicit in cases involving the states. Historians, such as Aviam Soifer, have detailed the evolution of federal powers and argued that the Constitution has not functioned to impose many limits on Congressional activity. ${ }^{348}$ The question is not whether unlimited federal power exists over states, but how to use it. 349

Identifying the stated vastness of federal powers vis-a-vis both states and Indian tribes does not require a conclusion that federal power ought to be used identically. For example, when Indian tribes and states go to the Supreme Court to obtain protection from Congress, should the Court respond with equal deference to Congress? ${ }^{350}$ One response is that the differing histories of the rela-

345436 US at 56.

${ }^{346} 469$ US 528 (1985).

${ }^{347}$ See Kaden, 79 Colum I Rev 847, 862-67 (cited in note 77), on whether the Congress is a forum responsive to states' interests. After Garcia, lobbying efforts did succeed in overturning portions of the statute that had formed the basis for that litigation. See Fair Labor Standards Amendments of 1985, Pub L No 99-150, 99 Stat 787 (Nov 13, 1985) amending 29 USC $\S \S 203,207$. Further, as Martha Field has explained, "if the Court does want to protect state interests, it has ample opportunity to do so without inventing new constitutional immunities." Field, 99 Harv L Rev 84, 115 (cited in note 20).

${ }^{348}$ Soifer, 57 U Colo L Rev 793, 797 (no historical basis for claim that constitution limits congressional power) (cited in note 80).

${ }^{349}$ See Cover, 95 Yale L J 1601 (cited in note 94).

350 A distinct question is to whom the tribes might go to obtain protection from the Supreme Court. See Ball, 1987 Am B Res F J at 137 (cite in note 21) ("Now the Court threatens to move against Indians when Congress refuses to do so and to employ equity, one of the great heads of the law, as its weapon."); Clifford M. Lytle, The Supreme Court, Tribal Sovereignty, and Continuing Problems of State Encroachment into Indian Country, 8 Am Indian L Rev 65 (1980); Karl J. Kramer, The Most Dangerous Branch: An Institutional Approach to Understanding the Role of the Judiciary in American Indian Jurisdictional Determinations, 1986 Wisc L Rev 989. For commentary on the inadequate protection af - 
tionships between "sovereigns" should yield different understandings of the limits of congressional authority. Unlike states, Indian tribes have no official protection in Congress from the Supreme Court. Moreover, Indian tribes are part of the federal government by virtue of conquest and by continued federal reliance on and interpretation of that conquest. Some have used the fact of conquest to argue for the unmitigated power of the federal government to control Indian tribal life. ${ }^{351}$ Others have taken the same fact of conquest to bolster the claim of a moral right to separatism. ${ }^{382}$ The oft-told story about the states is that they are a part of the federal government by virtue of consent. While some would revise that history, ${ }^{353}$ the claim of consent has given rise to arguments of limited federal power, that only some powers were ceded and the rest "reserved." Yet that very same constitutive event, consent, has also been the basis for findings of great federal power. ${ }^{354}$ Arguments based upon earlier moments in the history of the United States provide some, but not total, answers; something more than past wrongs and past covenants ${ }^{\mathbf{3 6}}$ is needed to decide whether the federal government should support multiple governments and how much variation in governing structures and norms to encourage.

\section{B. The Question of the Survival of "Other" Courts}

With fluctuations over time, the federal government and its courts have consistently permitted other (lesser) power centers to function and sometimes even to flourish. Federal courts have crafted doctrines of comity and deference, ${ }^{368}$ and have ceded juris-

forded by state courts to Indian tribes's federal rights, see John J. Gibbons, Federal Law and the State Courts, 1790-1860, 36 Rutgers L Rev 399, 427-436 (1984).

${ }^{3 s 1}$ See, for example, Justice Rehnquist for the Court in Oliphant, 435 US at 197 (jurisdiction of tribes depends upon what Congress has given).

${ }^{352}$ Williams, 1986 Wisc $L$ Rev at 293 (cited in note 89) (the federal government should "surrender" the doctrine of "discovery," which is Eurocentric, and accept the Indian tribes as possessing co-equal status). See also Rachel San Kronowitz, Joanne Lichtman, Steven Paul McSloy, Matthew G. Olsen, Comment, Toward Consent and Cooperation: Reconsidering the Political Status of Indian Nations, 22 Harv CR-CL L Rev 508 (1987) (relying on principles of international law to restructure relations between the United States and Indian tribes).

${ }^{3 s 3}$ See Ackerman, 93 Yale L J 1013 (1984) (cited in note 124); Ackerman, Discovering the Constitution, (cited in note 123).

ss4 Compare the majority and dissenting opinions in Garcia, 469 US at 530; 557 (Powell dissenting).

${ }^{3 s 5}$ See Michael Walzer, Exodus and the Revolution (Basic Books, 1985) (are Jews bound to tell the Passover story because of the covenant at Mt. Sinai or do they bind themselves when they tell the story?).

356 For interpretation of Eleventh Amendment doctrine as founded upon notions of 
diction and authority to other court systems - state and tribal and to quasi-court systems, such as agencies and arbitration. ${ }^{\mathbf{3 5 7}}$

What animates this support for other decision centers? Answers vary over time and with different actors. For some, the hope is that community-based processes still thrive in smaller units of government. ${ }^{388}$ Others claim a commitment to an "ethic of promising," 358 that the federal government entered into compacts with both the states and the tribes and must honor those compacts even though it might try to exercise the power of rescission. Yet another explanation comes from the uses that the federal government can find for states and tribes. For example, the federal system does not want to decide all the disputes in the country, but wants to maintain its elite status by having only a subset of cases and, sometimes, final authority over cases otherwise distributed..$^{360}$

Responses to the question about the continuing vitality of tribal and state governments emerge not only from the perspective of

comity rather than constitutionally-demanded jurisdiction divestiture, see Jackson, 98 Yale L J 1 (cited in note 20).

${ }^{367}$ Concern about federal court reconsideration of arbitration decisions parallels some of the issues raised by federal habeas corpus and the Hatch proposal. See United Paperworkers Intern. Union v Misco, Inc, $108 \mathrm{~S} \mathrm{Ct} \mathrm{364,} 374$ (1987) (court of appeals could not decline to enforce arbitrator's decision on public policy grounds); Delta Air Lines, Inc. $v$ Air Line Pilots Ass'n Internat'l., 861 F2d 665 (I1th Cir 1988) (reversing, as violative of public policy, arbitrator's decision that airline lacked "just cause" to fire a pilot who flew while intoxicated). See generally Hiroshi Motomura, Arbitration and Collateral Estoppel: Using Preclusion to Shape Procedural Choices, 63 Tulane L Rev 29 (1988).

${ }^{368}$ See Lawrence Rosen, Individualism, Community and the Law: A Review Essay, 55 U Chi L Rev 571, 582-83 (1988). For discussion of claim that local and state governments give more "voice" to minorities and women, see Merritt, 88 Colum L Rev 1, 8 (cited in note 81). See also Soifer, 57 U Colo L Rev at 796 (cited in note 80) ("Any accurate historical review of states' rights must include long traditions of racism and malapportionment, stretching well into the post-World War II era. ...."). Compare the claim of "civic republicanism" that participatory processes can function on a national scale. See also Frank I. Michelman, The Supreme Court: 1985 Term - Foreword: Traces of Self-Government, 100 Harv L Rev 4 (1986); Cass R. Sunstein, Beyond the Republican Revival, 97 Yale L J 1539 (1988).

${ }^{350}$ Wilkinson, American Indians at 121 (cited in note 22) ("These old laws emanate a kind of morality profoundly rare in our jurisprudence. It is far more complicated than a sense of guilt or obligation. ... Somehow, those old negotiations [of treaties] ... are tremendously evocative. Real promises were made on those plains, and the Senate of the United States approved them, making them real laws"). See also Wilkinson, 21 Creighton L Rev at 796 (1988) (cited in note 82). See also Clinton, 33 Stan L Rev at 1027 (1981) ("great nations, like great men, should keep their word") (cited in note 93).

${ }^{380}$ For arguments to send "routine" cases, such as those involving federal statutory claims and low monetary amounts, away from the federal courts, see Antonin Scalia, An Address, 34 Fed Bar News \& Journal at 252 (July/Aug, 1987); Robert Bork, Dealing with the Overload in Article III Courts, 70 FRD 231, 238-39 (1976) ("someone far less qualified than a judge" can assess such cases). For discussion of the need to keep final review in the federal courts, see Fallon, 101 Harv L Rev 916 (cited note 214). 
the federal government, but also from the perspective of the tribes and states. The tenacity of tribal governance, despite sustained efforts by the federal government to extinguish it, ${ }^{361}$ is remarkable. Given that Indian tribes are politically dispersed, have limited resources, and must contend with oppressive majoritarian rules, ${ }^{362}$ explanations of the resilience are needed. Similar exploration of the persistence of state governments is also needed, but the issue is less obvious. Just as Indian "tribes" are "historic inventions, tendentious and changing," ${ }^{363}$ so are states. Once the instability of the construct "tribe" is used to demonstrate the instability of the construct "state," then one is free to ask why and when to support the construction of either of those entities. Again, the answers need not be parallel, nor is the question solely one for the dominant culture to answer.

\section{The Assimilationist Pressures}

Inclusion of Indian tribal cases also clarifies the force of assimilationist pressures. ${ }^{364}$ Just as the federal government self-consciously cedes power, so it presses the "other" government to act as its surrogate. For better or worse, federal support for other court systems turns out, in many instances, to be contingent upon their performance as measured by federal court standards. This assimilationist pressure is desirable if one is enthusiastic about the standards imposed. Many of us celebrated the imposition of federal norms on communities that said that their culture, their custom, was to treat whites differently than blacks. Many of us are prepared to celebrate the imposition of federal norms, if they exist, that demand the non-subordination of women. ${ }^{365}$ Many of us worry about courts in which judges are dependent upon the executive or legislative branches, and many of us have a deep commitment to the values that go under the label "due process of law." State

${ }^{361}$ See Dozier, The Pueblos Indians at 19-22 (cited in note 165) ("The Pueblos have thus persisted, despite factional disputes, and appear to be as vigorous and vital today as during any period of their past." Id at 20). On efforts by first Spanish and then Anglo culture to change the Pueblos, see id at 106-18. See generally, Francis Paul Prucha, The Indians in American Society (U Calif Press 1985) ("The Indians, once facilely thought to be a vanishing race as a result of disappearance into the dominant white society, are instead persistent and clearly identifiable groups within the nation." Id at ix).

${ }^{362}$ Barsh and Henderson, The Road at 220-25 (cited in note 22).

ses Clifford, Predicament of Culture at 339 (cited in note 181).

${ }^{364}$ See Williams, 1986 Wisc L Rev at 279 (cited in note 89).

${ }^{365}$ See, for example, the requirement that business and civic organizations not discriminate against women. Rotary International v Rotary Club of Duarte, 107 S Ct 1940 (1987); New York State Club Association v City of New York, 108 S Ct 2225 (1988). 
courts have, upon occasion, failed to insist upon racial and gender equality and on due process in decision making. Hence, one might look to the federal government in an effort to persuade it to exercise its power and insist upon such rules.

Watching the interaction of federal, state, and tribal courts ${ }^{366}$ is instructive because one sees that the decision of the federal system to trump an "other's" decision varies with the strength of the federal norm at issue. When racial equality came to be seen as a national norm, toleration of the states' interest in racial inequality waned. ${ }^{367}$ When racial oppression was tied to criminal justice systems, federal attention was turned to state conviction processes. ${ }^{368}$ When federal interest in both racial equality and its impact on the administration of criminal justice wane, state sovereignty emerges again as a theme. ${ }^{369}$

When "federalization" is occurring, one has to ask whether the idea of "dual sovereigns," meaning state and federal courts, really has much meaning. Are these "other" court systems simply subsystems of the federal courts? Once again, the context of Indian tribe law sharpens a question implicit in federal courts' jurisprudence but often not articulated: We say we have dual sovereigns, with dual court systems, dual norm generation, and dual citizenship, ${ }^{370}$ but are the forces of federalization so strong that the duality is more true on paper and in rhetoric than in reality? Santa Clara Pueblo and Little Horn Bank help make plain that policies described as "theirs," as those of a sub-community, are always the product of interaction between a larger and a smaller group. The wealth of interdependencies demonstrates the complexity of "we"/ "they" distinctions and reminds us to be skeptical of the dominant

${ }^{366}$ Some of the issues are also relevant to the experiences of religious communities in the United States. See Weisbrod, $26 \mathrm{~J}$ Family L at 741-750 (cited in note 140). See also Employment Division, Oregon Dept of Human Resources $v$ Smith, 307 Ore 68, cert granted, 109 S Ct 1526 (1989) (does federal constitution prohibit state from denying unemployment compensation to Native Americans who ingested peyote in religious ceremony?).

${ }_{387}$ See Jolly, 4 Miss Col L Rev 217 (cited in note 288) (describing the desire of the South to be left alone, and the South as distinct from larger nation).

${ }^{363}$ See Henry v Mississippi, 379 US 443 (1965); Fay v Noia, 372 US 391 (1963).

${ }^{\text {s69 }}$ See McClesky v Kemp, 481 US 279 (1987) and death penalty litigation in general.

${ }^{370}$ When criminal defendants seek to defeat sequential prosecution by tribes and the federal government, by the state and federal government, or by state and state, those claims are rejected on the theory that the defendant has "dual citizenship" and each "sovereign" can prosecute without violating the double jeopardy bar. See United States $v$ Wheeler, 435 US 313 (1978); United States $v$ Lanza, 260 US 377 (1922); Heath v Alabama, 474 US 82 (1985). See generally Ronald J. Allen and John P. Ratnaswamy, "Heath v Alabama": A Case Study of Doctrine and Rationality in the Supreme Court, $76 \mathrm{~J}$ Crim L \& Criminol 801 (1985). 
group when it purports to be supporting the sovereignty of the "other."

\section{The Utility of the "Other"}

Given these interdependencies and assimilationist pressures, the question emerges: What is the point of the "other"? A large part of the record of tolerance of the "other" is of tolerance of similarity, not dissimilarity. The effort is to make the "other" like "us" - in the case of United States interaction with the Indian tribes, explicitly to "civilize" them. ${ }^{371}$ Understanding the attempts to change the "other" is important for federal courts jurisprudence, which assumes the actual existence of an "other" - the "other" branches of the federal government and the "other" sovereignty, the states. In the 1980s, "otherness" may be more formalistic than true. It is not only that, in separation of powers cases such as the special prosecutor and sentencing guideline cases ${ }^{\mathbf{3 7 2}}$ the $\mathrm{Su}$ preme Court has embraced non-formalistic overlapping powers, but also that the branches themselves have generated redundant institutions that readily find homes in any and all of the three branches. $^{373}$ One could similarly argue that the differences between state and federal courts are so marginal that only miniaturists could articulate the distinctions. Indeed, the claims of similarity are used by both federal judges and federal courts commentators to justify the authority given to state courts. ${ }^{374}$

One possible conclusion from acknowledging the assimilationist pressures is to perceive the states as not really "other," but as subdivisions of the federal government. If one believed that subdivisions were all that existed, then the argument for their continuation would rest upon a claim of efficiency - that the scale of the smaller units is better able to govern than the larger unit. Decision

${ }^{371}$ Prucha, The Indians In American Society 10 (cited in note 361) (federal Indian policy rested upon three premises; one premise, "paternalism," assumed that the "Indians' culture could and should be transformed to equal or approximate that of their white neighbors"). See generally Michael Paul Rogin, Fathers and Children: Andrew Jackson and the Subjugation of the American Indian (Knopf, 1975).

372 Morrison v Olson, 108 S Ct 2597 (1988); Mistretta v United States, 109 S Ct 647 (1989).

${ }^{373}$ For example, the Sentencing Commission was attacked for wrongly being in the judicial branch and for wrongly being out of the judicial branch. Mistretta, 109 S Ct 647 (1989). Similarly, adjudication could be based in either courts or agencies. See Commodity Futures Trading Comm'n v Shor, 478 US 873 (1986).

${ }^{374}$ See, for example, Justice Powell's discussion in Stone v Powell, 428 US 465 (1976); Henry M. Hart, The Power of the Congress to Limit the Jurisdiction of the Federal Courts: An Exercise in Dialectic, 66 Harv L Rev 1362 (1953). 
making in cases about federalism would then be governed by views about whether the smaller unit's claim enhances its capacity to serve as a subdivision of the federal government.

But there is a risk of overstatement. The state courts are not totally clones of the federal courts. At some points, state courts announce rules of law and of practice that are at some distance from the federal courts. ${ }^{375}$ And, despite enormous federal pressures, tribal courts are still "struggling to maintain their identity." 376 There are assimilationist pressures but not complete assimilation. Something more than subdivisions of the federal government currently exist.

How can one capture the differences? This question can be clarified by an example from feminist discussions of how to describe "women." Some feminists compare women's and men's methods of acquiring knowledge and making decisions and then make claims about "women's ways." that what are ascribed to "women" are attributes of the powerless, who lack the ability to exercise control and are always supplicants to the powerful. ${ }^{378}$ Both female and male identities are forged out of this interaction, and reordering the relationships of power requires changes on both sides. Similarly, "state," "Indian tribe," and "federal government" are identities forged in relationship to each other. As James Clifford has written, "[g]roups negotiating their identity in contexts of domination and exchange persist, patch themselves together. . . . Metaphors of continuity and 'survival' do not account for complex historical processes of appropriation, compromise, subversion, masking, invention, and revival." 379

From the perspective of the dominant society, the question is how much "subversion" and "invention" should be tolerated and encouraged. At the core of federal courts' jurisprudence is a ques-

${ }^{375}$ See, for example, differing standards on fugitive slave laws, described in Robert $M$. Cover, Justice Accused 211-225 (Yale U, 1975) and in Gibbons, 36 Rutgers L Rev at 436-447 (cited in note 350); differing standards on illegal searches and seizures, as set forth in $\mathrm{Michi}$ gan v Long, 463 US 1032 (1983), and in People v Long, 419 Mich 636, 359 NW2d 194 (1984) (especially Kavanaugh, J, concurring).

${ }^{378}$ Wiehl, NY Times at B7 ((cited in note 312).

${ }^{377}$ See, for example, Gilligan, In a Different Voice (cited in note 41). See also Mary Field Belenky, Blythe McVicker Clinchy, Nancy Rule Goldberger, and Jill Mattuck Tarule, Women's Ways of Knowing: The Development of Self, Voice, and Mind, (Basic Books, 1986).

${ }^{378}$ MacKinnon, Feminism Unmodified at 432-45 (cited in note 173). See also Christine A. Littleton, Feminist Jurisprudence: The Difference Method Makes, 41 Stan L Rev 751, 762 (1989).

${ }^{379}$ Clifford, Predicament of Culture at 338 (cited in note 181). 
tion that has often gone under the name of "sovereignty"380 but may more fruitfully be explored in the context of difference. ${ }^{381}$ If the word "sovereign" has any meaning in contemporary federal courts' jurisprudence, its meaning comes from a state's or a tribe's ability to maintain different modes from those of the federal government. The United States has often made claims about the richness of its pluralist society - made claims that the loss of state or tribal identity would not only be a loss to states and tribes, but would also harm all citizens because of the benefit of living in a country in which not all are required to follow the same norms. Some deep-seated emotional respect for group governance may be at work here, some sense that these self-contained communities are "jurisgenerative" (again, to borrow from Robert Cover) ${ }^{382}$ and that their traditions and customs must sometimes be respected and preserved. ${ }^{383}$ In the tribes, cities, states, and regions of the country, one can find not only individuals, but also the individual as part of a community - a community that has had continuity over time. In these communities there are social ties, there is a shared history, there is a network of relatedness. In contrast, the federal system appears to some as individualistic and atomistic. We are attracted by these smaller institutions, these subsets, these multiple sovereignties; we like the scale, the sense of history, the intimacy. ${ }^{384}$

But we also know that some communities are communities of oppression. In Marilyn Friedman's words, "[b]esides excluding or suppressing outsiders, the practices and traditions of many communities are exploitative and oppressive toward many of their own members. This problem is of special relevance to women."38s Of course, interpretations of communities as "exploitative and oppressive" depend upon the perspective of the viewer. ${ }^{386}$ While one

${ }^{380}$ See Rapaczynski, 1983 S Ct Rev 341 (cited in note 79) (discussing limited utility of term "sovereignty").

${ }^{381}$ See Minow, 101 Harv L Rev 10 (cited in note 168).

${ }^{382}$ Cover, 97 Harv L Rev 66 (cited in note 287).

sss See Ball, 1987 Am B Found Res J at 138 (cited in note 21) ("Tribes . . offer us hope. . . Tribalism offers the hope of empowerment"). See also Garet, 56 S Cal L Rev at 1062-65 (the values of sociality and communality) (cited in note 253). Compare Cover's discussion of when courts should be "jurispathic," 97 Harv L Rev at 66-68 (cited in note 287).

384 See Kathleen M. Sullivan, Rainbow Republicanism, 97 Yale L J 1713, 1714 (1988) for discussion of the different legal treatment accorded "[ $t$ ]wo sorts of 'groups,", "involuntary" ones, based upon national origin, gender, race, ethnicity, and "voluntary" groups, including families, social and political clubs, religions, and unions. See also Garet, 56 S Cal L Rev 1001 (cited in note 253).

s8s Marilyn Friedman, Feminism and Modern Friendship: Dislocating the Community, 99 Ethics 275, 281 (1989).

386 See Minow, 101 Harv L Rev at 45 (cited in note 168). 
reading of Julia and Audrey Martinez's decision to go to federal court to obtain alteration of membership rules could be that they found the Santa Clara Pueblo to be oppressive to women, many interpretations are possible. In one sense, the very act of asking the federal court to dictate to the Pueblo could be understood as an act of self exclusion. By seeking federal court assistance, Ms. Martinez signaled that she stood outside the community in which she sought to have her children included and perceived the community as a source of oppression. In another sense, the decision to seek federal court help could be understood as demonstrating how deep Ms. Martinez's affiliation with the Pueblo was, for she was willing to risk a good deal of hostility to enable her children to continue to live on the Pueblo and to inherit land as members of the Pueblo. ${ }^{38 z}$ Ms. Martinez was not alone in seeking federal court relief from tribal decisions. Many other cases have been filed by Indians challenging the decisions of their communities, indicating that, at least for some, embeddedness in a jurisgenerative community may be problematic, that "communities of place" may not always be responsive to the needs of their members. ${ }^{388}$

How are we to interpret the Supreme Court's instruction to Ms. Martinez? "You are a citizen of the United States, but go back to your community and make your claims there." We must acknowledge that the decision is an act of exclusion, that Ms. Martinez's claim of connection to the United States was rejected at the same time that the Court affirmed both her affiliation with the Santa Clara Pueblo and federal power to control the relationship between her and the Pueblo - had Congress chosen to exercise its power. ${ }^{389}$ How are we to interpret the Supreme Court's instruction

387 "... [W] [Wen an Indian woman attempts to claim that her family is an Indian family, ... [why is it] called a threat to cultural survival?" MacKinnon, Feminism Unmodified, at 67 (cited in note 173). In yet a third reading, one could see the interaction with the federal court as irrelevant; Ms. Martinez's children continue to live on the Pueblo, speak its language, and participate in its religious life.

${ }^{388}$ Friedman, 99 Ethics at 284-290 (cited in note 385) makes a distinction between "communities of choice" and those of "place" and urges some skepticism of the vogue of communitarianism and republicanism in political thought. See also Mark Tushnet, Red, White, Blue 314 (Harvard, 1988) ("revitalizing federalism might be a bad idea overall. Under current political circumstances a program favoring decentralization might end up with a system in which political authority is decentralized while economic power remains tightly controlled").

389 The testimony of Robert Walters, before the United States Commission on Civil Rights, captures this problem. The Navajo tribal council removed Mr. Walters from his position in its court. He criticized the lack of federal rights enforcement and stated: "Why are we [Indian tribes] being treated as an outsider within the United States?" U.S. Commission on Civil Rights Hearings at 141 (Aug 13-14, 1987, Flagstaff, Ariz) (cited in note 327). 
to Lloyd Powell and David Rice, habeas corpus petitioners in the Stone $v$ Powell case? The Court said in essence that they had federal Fourth Amendment rights which the lower federal courts had found to have been breached, ${ }^{380}$ but that, since state courts had decided the claims, no federal review was permitted. These seem to be federal statements enforcing the continued importance of "communities of place" and ignoring claims that those communities are at least nonresponsive if not outright oppressive. These also seem to be statements to which the federal courts are reluctant to respond - because they are too busy, too important, too tired, too besieged, too confused. Yet we know that sometimes the federal courts do respond, that federal judges responded when New York habeas corpus petitioner Charles Noia claimed his confession had been physically coerced ${ }^{301}$ and when "non-Indian" Mark David Oliphant sought to avoid a tribal court. ${ }^{382}$ The task for federal courts' students and scholars is to try to understand what animates federal decisions to sustain the power of the "other," what prompts decisions to diminish that power, and what criteria should lead us to praise or criticize such decisions.

For example, if one believed in the utility of the "other" beyond that as a subdivision of the federal government, then the underlying reasons for that utility would shape how the federal government should respond when conflicts emerge. If notions of "checks and balances" are at work, if the "other" must have power so as to limit and diffuse the power of the federal government, then federal courts should sustain differences that enhance the ability of the other to hold power sufficient to check the federal government. $^{393}$ One of the problems with the Santa Clara Pueblo decision is that the Court never confronted the claim that the Pueblo was being used for some purposes as a subdivision of the federal government - to distribute Indian benefits for the government. ${ }^{394}$ Yet another problem in Santa Clara Pueblo was the im-

${ }^{300}$ See Powell $v$ Stone, 507 F2d 93, 96 (9th Cir 1974) and Rice $v$ Wolff, 513 F2d 1280, 1289 (8th Cir 1975), both reversed in Stone v Powell, 428 US 465 (1976).

${ }^{302}$ Fay $v$ Noia, 372 US 391 (1963). See generally Larry W. Yackle, Explaining Habeus Corpus, 60 NYU L Rev 991 (1985); Judith Resnik, Tiers, 57 S Cal L Rev 837 (1984).

${ }^{392}$ Oliphant $v$ Suquamish, 435 US 191 (1978).

${ }^{393}$ See, for example, Robert F. Nagel, 1981 S Ct Rev 81 (cited in note 344). See also Robert M. Cover, The Uses of Jurisdictional Redundancy: Interest, Ideology, and Innovation, 22 Wm \& Mary L Rev 639 (1981).

${ }^{394}$ One possible solution would have been for the Supreme Court to have distinguished between the implications of membership for the Pueblo and for the federal government. The Court could have required the provision of federal money to the Martinez family. The suggestion does not respond to all that the Martinezs sought; they wanted federal money to 
plicit public/private distinction endorsed by the Court. The arena in which tribes have most authority are "intratribal disputes," matters including issues such as membership, marriage, and family matters. ${ }^{385}$ To cut off that set of activities from federal rule making is to assume that the structures of families and communities are not decisions of national political importance. Hence, "letting" tribes have control over these issues is not recognizing them as serious power holders, but only as holding power over that which has little import.

But Santa Clara Pueblo did not send only Julia and Audrey Martinez's claim for non-discriminatory membership rules back to tribal governments for decision. The Supreme Court said that, absent Congressional direction, no federal court could entertain any private civil action for violation of the ICRA, whether those claims are of denial of equal protection, deprivations of free speech, illegal searches and seizures, wrongful takings, or denial of due process. ${ }^{396}$ One might then conclude that Santa Clara Pueblo is evidence of a serious commitment to the tribal courts as competing power centers for the enforcement of different cultural norms. However, the Court justified its refusal to permit federal court jurisdiction by stating that "[t]ribal forums are available to vindicate rights created by the ICRA [which had] ... the substantial and intended effect of changing the law which these forums are obliged to apply." 397 Tribal courts have the power to decide, but their decisions must be in accordance with the federal law, albeit with no federal court supervision of compliance.

If tribal courts are simply vehicles for federal lawmaking, what is the definition of tribal "sovereign" interests that the Court claimed in Santa Clara Pueblo to respect? "Sovereignty" in this context seems to mean that a tribe need not explain itself to the federal courts, but must follow federal law. (Will tribes, like state

build housing on the Pueblo and wanted the children to inherit that housing. Further, this suggestion requires believing that the individual Indian should be the appropriate recipient of at least some benefits, rather than believing that the benefits belong to the Pueblo, as a community, to allocate as it wishes. See Bittker, The Case for Black Reparations, 71-87 (cited in note 228) ("compensation to groups or individuals?").

395 436 US at 59-61. Justice Marshall included "matters involving commercial and domestic relations" as central to self governance. Compare Brendale v Confederated Tribes and Bands of Yakima Indian Nation, 109 S Ct 2994 (1989) (limits on tribal power when controlling reservation land owned by non-members).

${ }^{398}$ Id at 69. See 25 USC $\S 1302$ (1986).

397436 US at 65 (footnote omitted). As the Court knew, the Martinez family had been unsuccessful in its efforts to obtain relief from the tribe. For discussion of the assimilationist goals of ICRA, see Burnett, 9 Harv J Leg at 588-89 (cited in note 264). 
courts, be presumed by federal judges to be equal to federal courts in their fidelity to federal law?) But perhaps a stronger definition of sovereignty can be pulled from the lines of the Santa Clara Pueblo opinion. If the tribal courts are the interpreters of the meaning of federal law, can use tribal law, and have the authority to interpret without federal court oversight, ${ }^{398}$ then divergent, idiosyncratic expressions can emerge. "The vast gulf" that Justice Marshall referred to "between tribal traditions and those with which the federal courts are more intimately familiar" 398 can be preserved and even enlarged. But, as Oliphant and Little Horn Bank remind us, when non-Indians are involved and tribal criminal law is invoked, or when non-Indian creditors seek enforcement of their claims, federal court interest in "tribal sovereignty" wanes.

One way that the federal government can use the "other" sovereign is to learn something about itself. Santa Clara Pueblo and Little Horn Bank help to clarify that what the federal government is prepared to tolerate in "them" depends upon how it defines itself and what effect it perceives "their" decisions to have. When federal and "other" norms converge, toleration and claims of "sovereignty" are easy to make. One explanation of Santa Clara Pueblo is, in general, that Indian tribes' treatment of their members is not of central concern to federal law, and, in particular, that membership rules that subordinate women do not threaten federal norms $^{400}$ (either because federal law tolerates women holding lesser status than men or because federal law has labeled the issue one of "private" ordering and non-normative). How long can this federal disinterest be maintained? On several reservations, non-Indians or non-members of a governing tribe comprise a substantial and sometimes a majority of the population; "they are an integral part of the community." ${ }^{401}$ Further, feminists hope that illumination of

${ }^{388}$ Other mechanisms for federal oversight, arguably equally as intrusive, exist. The Secretary of Interior, the Bureau of Indian Affairs, and the Civil Rights Commission have taken on administrative review of tribal courts. See Alvin J. Ziontz, After "Martinez": Civil Rights Under Tribal Government, 12 UC Davis L Rev 1, 29-33; Clinton, AALS Speech at 15-24 (cited in note 327); U.S. Commission on Civil Rights Hearings (cited in note 327).

${ }^{392}$ Santa Clara Pueblo, 436 US at 72 n 32.

100 Another is to understand the Court's decision that no private right of action was available as an exercise of "passive virtue," for it avoided a ruling on the merits of the underlying claim. For comments questioning both the passivity and the virtue of the "passive virtues," see Lee A. Albert, Standing to Challenge Administrative Action: An Inadequate Surrogate for Claim for Relief, 83 Yale L J 425 (1974); Sunstein, Interpreting the Regulatory State (cited in note 10). Compare Pennhurst State School \& Hosp. v Halderman, 465 US 89 (1984) (state sovereignty interests require that federal courts not decide whether state officials violate state law).

${ }^{201}$ Greywater $v$ Joshua, 846 F2d 486, 493 (8th Cir 1988), discussing the Devils Lake 
the political content of the "personal" will result in legally-mandated reordering. The Supreme Court's tacit reliance upon dichotomies such as Indian and non-Indian, public and private, demonstrates the ways in which the Santa Clara Pueblo opinion avoided responding to the underlying problems: the coherence of the conception of Indian tribes as a "separate people"402 (in the sense of disconnected) and the assumption of a "domestic sphere" as apolitical. Interconnections weave together Indians and non-Indians, families and the "market." only postponed. ${ }^{404}$

While Santa Clara Pueblo illustrates deep underlying convergences between the tribal conception of its role and the federal conception, Little Horn Bank and the Hatch proposal exemplify moments when normative divergences are closer to the surface. ${ }^{405}$ At some point, from the perspective of the dominant group, the "vast gulf" becomes too vast - differences emerge that the federal government tries to obliterate. At such points, the federal government attempts to remind the dominated group of its dependence upon the larger collective and works to bring the smaller group into compliance with federal norms. Implicit in the Little Horn Bank decision is a view that courts with procedures different from the federal ones may cause harm to creditors' ability to collect debts and may undermine the fluidity of commercial transactions. Toleration of such differences in this "public" arena of debt collection were not to be countenanced by at least one federal district court. Further, the techniques for assimilation need not always be judicially or legislatively based. Economic pressures may also be exerted to try to bring tribal courts into compliance with federal norms; banks can refuse to do business if their debt collection efforts will be thwarted by tribal or state courts. ${ }^{406}$ As a descriptive

\section{Sioux Reservation.}

${ }^{402}$ Kagama, 118 US at 381.

${ }^{403}$ Frances E. Olsen, The Family and the Market: A Study of Ideology and Legal Reform, 96 Harv L Rev 1497 (1983).

104 See, for example, the disputes about the reach of tribal jurisdiction over non-member Indians, discussed in note 109. See also United States v Mazurie, 419 US 544, 557 (1975) (authority of Wind River Tribes over issuing liquor licenses to nonmembers).

${ }^{40 s}$ For discussion of the depth of the tribal "challenge to the core values and traditional norms assertedly embodied in American legal thought," see Robert A. Williams, Jr., Jefferson, The Norman Yoke, and American Indian Lands, 29 Ariz L Rev 165, 167 (1987).

${ }^{108}$ Trentadue, 13 Am Indian L Rev 1, 49 (cited in note 330) (Indian tribal "governments certainly are vested with authority, but the individual members and perhaps the tribes as a whole are paying a price for their separate system of government. This price seems to include not only a reduction in consumer credit to tribal members, but a corresponding denial of private sector development moneys as well"). 
matter, we must note these assimilationist pressures; as a normative matter, we must debate the desirability of them.

An "other" sovereign serves a valuable purpose for the federal government. The degree of toleration of the "other" sovereign's decisions enables the federal government to make plain what its own values are. ${ }^{407}$ One version of this relationship is the "laboratory" that Brandeis described ${ }^{408}$ - in which the states are places of experimentation. An alternative conception is the dialectic interaction that Robert Cover and Alexander Alienkoff mapped. ${ }^{409}$ If one believes in the utility of that dialogue, then one would be supportive of enabling two voices, of cohabitation rather than domination, of having governments with different "interests" and "ideology" thus enabling "innovation." "10 The most difficult issues for federal courts' jurisprudence are to explain how to engender differences, how deep the respect should be for difference, when the federal government's right to assert a baseline exists, and then to ascertain where that federal floor should be. Constitutional and case law exegesis alone cannot accomplish these tasks. Rather, on-going relational struggles illuminate the changing shapes of the floors that are continually to be sought.

Article III established the federal courts as the second set of courts in the federal system. Federal courts were at first the "other" courts, in the feminist sense of the word. "11 "Other" - and generating deep suspicion and hostility, during the era when state courts were more entrenched, had a longer history, commanded equal or more loyalty. Over time, the federal courts, and the gov-

${ }^{107}$ Note that the idea of a federal "floor" of norms might engender differential levels of scrutiny of "other" courts' activities. A variable standard of review is akin to what was argued by the ACLU in its amicus brief, on behalf of the Martinez family, to the Supreme Court in Santa Clara Pueblo. Brief for Amicus Curiae American Civil Liberties Union, Santa Clara Pueblo v Martinez, No. 76-682, 18-20 (Oct Term, 1976). In contrast, the many Indian tribes that filed amicus briefs on behalf of the Pueblo argued that any federal scrutiny was impermissible. Amicus briefs filed on behalf of the Pueblo included those by Confederated Tribes of the Colville Indian Reservation, the National Tribal Chairmen's Association, the Shoshone and Arapahoe Tribes of the Wind River Indian Reservation, and the National Congress of American Indians.

${ }^{408}$ New State Ice Corp v Liebmann, 285 US 262, 311 (1932) (Brandeis dissenting).

109 Robert M. Cover and T. Alexander Aleinikoff, Dialectical Federalism: Habeus Corpus and the Court, 83 Yale L J 1035 (1977).

410 See Cover, $22 \mathrm{Wm} \&$ Mary L Rev 639 (cited in note 393).

"11 Simone de Beauvoir, The Second Sex xviii-xix (Knopf, 1952) ("Thus humanity is male and man defines woman not in herself but as relative to him ... he is the Subject, he is the Absolute - she is the Other") (footnote omitted). See also Marilyn Strathern, An Awkward Relationship: The Case of Feminism and Anthropology, 12 Signs 276, 290 (1987) ("the conscious creation of self by seeing its difference from the Other"). 
ernment whose power they deploy, have emerged as "the" courts, with the power to define the roles of the "other" courts. Federal courts constantly define themselves in the context of the other institutions that resemble them. Federal courts are not state courts, not agency courts, not legislative courts, not tribal courts, not local, but national tribunals. Out of this relationship comes descriptions of what norms are deeply held and of the being itself. ${ }^{412}$ But the lines are not etched in stone; the boundaries do not remain stable, the "other" changes and with it the self.

\section{ConcLuSION}

Federal courts jurisprudence is about the uses of courts as vehicles of culture and is about the culture the courts carry. When Felix Frankfurter, Wilber Katz, Harry Shulman, Henry Hart, and Herbert Wechsler framed a course of study about the federal courts, they were preoccupied with the courts' role in forging a national identity while maintaining a sphere of activity for the states. Since the era in which these law professors worked, a wealth of federal legislation, of Supreme Court decision making, of economic nationalization, of personal mobility has transformed the country. Whole areas of law have become "federalized," as constitutional interpretations and legislative enactment have made federal rules paramount. The federal government is a pervasive force in the life of cities, states, and citizens.

Given this "federalization," the question remains: why have two sets of courts and sets of government? But rather than wither away, state courts seem to be actively in the litigation business. And the federal courts have upon occasion supported the decision making authority of yet another set of courts, tribal courts, and, more recently, of arbitration and agency-based adjudication. Thus, students of the federal courts have much to learn about the longevity and the persistence of these multiple structures.

Thus far, the official canon of the federal courts has not included the relationship between the federal courts and Indian tribes. Little is said about the federal courts' role - sometimes destroying Indian tribal culture and occasionally respecting it. We

112 James Clifford, in Predicament of Culture at 281 (cited in note 181) quotes the following exchange, between a lawyer and a member of the Mashpee tribe, during the trial to establish the Mashpee claim to Massachusetts' land.

"Question: How was your youth different from that of any small-town youth? Answer: We were different. We knew we were different. We were told we were different." 
have also not much spoken of the sources of federal power over Indian tribes: conquest, violence, force. In the context of states, basic aspects of the power relationship are similarly not much discussed; when the Supreme Court imposes federal rules, it refers to parts of the Constitution, not to the Civil War. Yet it was the Civil War and then again the use of federal force in the 1960s that established the federal power to insist that federal norms trumped "state sovereignty."

It is time, I think, to review the stories we have been telling about the federal courts, to acknowledge the role played by brute force, to make plain the limits of constitutionalism and of history in explicating constitutionalism. It is time to revise the canon, to include texts less noble than the ones we have preferred, and with their inclusion, learn more about the present and what future we want to craft. 
